\title{
FLORA DA SERRA DO CIPÓ, MINAS GERAIS: ASTERACEAE - EUPATORIEAE
}

\author{
FERNANDA LECHADO CONTRO \& JIMI NAOKI NAKAJIMA
}

\author{
Instituto de Biologia, Universidade Federal de Uberlândia, Av. Pará 1720, \\ 38405-320 - Uberlândia, MG, Brasil. \\ Autor para correspondência: lechadoferdi@hotmail.com
}

\begin{abstract}
Flora of the Serra do Cipó, Minas Gerais: Asteraceae - Eupatorieae). The study of the tribe Eupatorieae is part of a wider project entitled "Flora of the Serra do Cipó, Minas Gerais, Brazil". In that area the tribe is represented by the following genera with their respective numbers of species: Acritopappus (1), Ageratum (3), Ayapana (1), Campuloclinium (1), Chromolaena (20), Disynaphia (1), Grazielia (1), Heterocondylus (2), Koanophyllon (1), Mikania (28), Praxelis (4), Pseudobrickellia (3), Stevia (3), Stomatanthes (1), Symphyopappus (6), Trichogonia (4) and Vittetia (1). In this study we present keys to the genera and species, descriptions of genera and species, comments on taxonomy, geographic distribution, habitats and illustrations.
\end{abstract}

Key words: Compositae, Espinhaço Range, rocky fields, taxonomy.

Resumo: (Flora da Serra do Cipó, Minas Gerais: Asteraceae - Eupatorieae). O estudo da tribo Eupatorieae é parte de um projeto mais amplo denominado "Flora da Serra do Cipó, Minas Gerais, Brasil". Nesta área, a tribo está representada pelos seguintes gêneros e seus respectivos números de espécies: Acritopappus (1), Ageratum (3), Ayapana (1), Campuloclinium (1), Chromolaena (20), Disynaphia (1), Grazielia (1), Heterocondylus (2), Koanophyllon (1), Mikania (28), Praxelis (4), Pseudobrickellia (3), Stevia (3), Stomatanthes (1), Symphyopappus (6), Trichogonia (4) and Vittetia (1). Neste estudo apresentamos chaves de identificação para gêneros e espécies, descrições dos gêneros e espécies, comentários sobre taxonomia, distribuição geográfica, habitat e ilustrações das espécies.

Palavras-chave: Cadeia do Espinhaço, campos rupestres, Compositae, taxonomia.

\section{Tribo Eupatorieae Cass.}

Ervas, subarbustos, arbustos ou arvoretas, raramente árvores. Ramos cilíndricos, multicostados, pubescentes, glandulosos ou glabros. Folhas opostas, raramente alternas ou verticiladas, pecioladas ou sésseis, margem inteira, crenada, serreada, denteada ou repanda. Capítulos raramente solitários ou em capitulescências de panículas, cimas ou tirsos, homógamos e discoides; invólucro cilíndrico, campanulado ou cilíndrico-campanulado, subimbricado, imbricado ou eximbricado, brácteas involucrais em 2 ou muitas series. Receptáculo plano, plano-alveolado, convexo ou cônico, paleáceo, piloso ou glabro. Capítulo com 4- mais de 80 flores, corola tubulosa, limbo diferenciado ou não, brancas, azuis, arroxeadas ou rosa-intenso, mas nunca amarelas. Anteras ecalcaradas, com apêndice apical. Ramos do estilete lineares, longamente divididos, papilosos, mamilosos ou tricomas coletores, área estigmática aparente ou não. Cipselas obcônicas ou prismáticas, raramente comprimidas; carpopódio presente ou não.
Pápus plumoso, cerdoso barbelado, raramente coroniforme, cerdas unidas na base ou livres.

Eupatorieae Cass. é uma das maiores tribos de Asteraceae, compreendendo cerca de 180 gêneros e aproximadamente 2400 espécies, distribuídas, principalmente, na região Neotropical, com poucas espécies na América do Norte, Canadá e Hemisferio Leste (King \& Robinson 1987). A tribo pode ser caracterizada pela presença de folhas opostas, raramente alternas, capítulos discoides, homógamos, corola nunca amarela, ramos do estilete longos e sem pilosidade abaixo do ponto de bifurcação.

No Brasil existem 85 gêneros e 608 espécies, distribuídas em todas as regiões e estados do país (Asteraceae in Flora do Brasil 2020 em construção, 2017.). $\mathrm{Na}$ área de estudo a tribo está representada por um total de 84 espécies pertencentes a 17 gêneros.

Bibliografia básica: King \& Robinson (1987), Bautista (2001), Esteves (2001), Nakajima (2001), Ritter \& Miotto (2005), Almeida (2008), Baldwin (2009), Funk et al. (2009), Roque, Bautista \& Motta (2012), Fernandes (2014), Hattori (2014), Quaresma (2014).

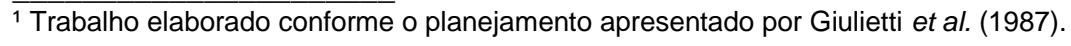

DOI: 10.11606/issn.2316-9052.v35ip113-162

Bol. Bot. Univ. São Paulo, São Paulo, v. 35, p. 113-162, 2017 
1. Capítulos com mesmo número de flores e brácteas.

2. Capítulos com 4 flores e 4 brácteas involucrais

10. Mikania

2'. Capítulos com 5 flores e 5 brácteas involucrais

1'. Capítulos com número de flores e brácteas distintos.

3. Cerdas do pápus unidas na base, formando um anel.

4. Capítulos com 20-70 flores

4'. Capítulos com 5 flores.

5. Pápus bisseriado

5'. Pápus unisseriado.

6. Folhas alternas espiraladas, sésseis a subsésseis; invólucro 2-seriado

13. Stevia

6'. Folhas opostas, pecioladas; invólucro 3-seriado

3'. Cerdas do pápus não unidas na base, nem formando um anel, ou pápus ausente ou vestigial.

7. Pápus ausente ou vestigial.

8. Folhas sésseis, fasciculadas; receptáculo paleáceo

8'. Folhas longo-pecioladas (até $3 \mathrm{~cm}$ ), opostas; receptáculo glabro

7'. Pápus presente.

9. Corola com lobos pubescentes; pápus plumoso

9'. Corola com lobos glabros, glanduloso-pontoados, com tricomas glandulares ou não pubescentes; pápus cerdoso.

10. Invólucro com todas as brácteas caducas; receptáculo cônico

10'. Invólucro com as brácteas persistentes, receptáculo plano ou convexo.

11. Capitulescência em panículas piramidais

11'. Capitulescência em panículas corimbiformes ou tirsos, raramente terminal e solitária.

12. Capítulos com 4-7 flores.

13. Capítulos com 5-6 flores; ramos do estilete claviformes

13'. Capítulos com 4 flores; ramos do estilete lineares

8. Heterocondylus

Capítulos com mais de 7 flores (até 70 flores).

14. Invólucro eximbricado; bisseriado.

15. Capítulos com até 37 flores; receptáculo cônico e glabro

15'. Capítulos com 21 flores; receptáculo plano e piloso

15. Symphyopappus

Invólucro imbricado, 3-6-seriado.

16. Plantas cobertas por tricomas glandulares não sésseis; receptáculo glabro

16'. Plantas cobertas por tricomas glandulares sésseis ou tricomas multicelulares;

receptáculo com ou sem páleas

6. Disynaphia

7. Grazielia

2. Ageratum 1. Acritopappus

16. Trichogonia

11. Praxelis

9. Koanophyllon

14. Stomatanthes

12. Pseudobrickellia

. 4. Campuloclinium 17. Vittetia

3. Ayapana

5. Chromolaena

\section{Acritopappus R.M.King \& H.Rob., Phytologia 24: 401.1972.}

Arbustos eretos. Ramos cilíndricos a 6angulados, glabros. Folhas opostas, curto a longopecioladas (pecíolo até $3 \mathrm{~cm}$ ); lâmina ovada, elíptica, lanceolada ou linear; base geralmente aguda, ápice curto-agudo a longo-acuminado, margem serrada a subserrulada ou quase inteiras. Capitulescência terminal ou às vezes frondosas, ramos subcimosos; pedúnculos curtos, hirsutos, hirtos ou glabros. Invólucro eximbricado, 2-3-seriado. Brácteas involucrais 5-25, iguais a subiguais. Receptáculo plano a convexo, glabro ou com páleas lineares. Capítulos com 5-30 flores, corola lilás claro, estreitamente funeiforme, com pequenas glândulas externamente; lacínias triangulares, mais longas que largas, papilas curtas internamente. Anteras com apêndice oblongo-triangular. Ramos do estilete com base não alargada, lineares, curto-papiloso. Cipselas prismáticas, glabras; carpopódio distinto, curto. Pápus vestigial, curto-coroniforme ou com poucas aristas.

O gênero possui 17 espécies e é endêmico do Brasil (King \& Robinson, 1987; Bautista, 2000). As espécies encontram-se distribuídas na Bahia, Ceará, Minas Gerais, Pernambuco, Rio de Janeiro, São Paulo e Sergipe e ocorrendo nos domínios da Caatinga, Cerrado e Mata Atlântica.

O gênero foi estabelecido por King \& Robinson baseado, principalmente, pela presença de pápus diminuto e difere de Ageratum, gênero mais próximo, pela presença de receptáculo plano a convexo e folhas sem pontoações glandulosas (King \& Robinson, 1972).

\subsection{Acritopappus longifolius (Gardner) R.M.King} \& H.Rob., Phytologia 24: 403. 1972.

Fig. $1 \mathrm{~A}-\mathrm{C}$

Arbustos, até $1,2 \mathrm{~m}$ alt. Ramos cilíndricos, multicostados, glabros. Folhas opostas, pecíolos 1,5$3,06 \mathrm{~cm}$, glabros; lâminas 2,2-12,2 cm compr., 0,14$3,05 \mathrm{~cm}$, lanceoladas, ápice longo acuminado, base aguda, margem serreada, ambas as faces glabras, craspedódroma. Capitulescência em panículas corimbiformes, capítulos com pedúnculo 1,5-2,2 mm, glabro, resinoso/vernicoso; invólucro estreitocampanulado, 2,9-4,7 mm compr., 1,8-4 mm larg., 3(4)-seriado, brácteas involucrais $1,9-4,6 \mathrm{~mm}$ compr., 0,8-1,3 mm larg., lanceoladas, ápice arredondado, margem inteira, glabras, resinosas/vernicosas. 
Receptáculo plano, glabro. Capítulos com 16-19 flores, corola, com tubo 1,3 $\mathrm{mm}$ compr., fauce alargada, glanduloso-pontoada, lacínias $0,4 \mathrm{~mm}$, papilosas internamente, glanduloso-pontoadas externamente. Anteras com base arredondada, apêndice apical emarginado. Ramos do estilete lineares, ápice obtuso, papilosos. Cipsela prismática, 0,9-2,4 mm compr., 0,3-0,5 mm diâm., 5-costada, glabra; carpopódio inconspícuo. Pápus ausente.

Material examinado: Minas Gerais, Santana do Pirapama, Serra da Lapa, trilha da Cachoeirinha, $19^{\circ} 00^{\prime} 22 " S$ e 4345'20"W, 19.Il.2007, fl. e bot., V.C. Souza et al. 32736 (ESA, RB); Santana do Pirapama, Serra da Lapa, Distrito de

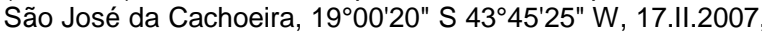
fl., V.C. Souza et al. 32529 (ESA, HUFU); km 128, 15.IV.1950, fl., A.P. Duarte 2488 (R, RB); Santana do Riacho, Fazenda Inhame, Serra Mineira, 20.III.1982, bot. e fl., J.R. Pirani et al. CFSC 7996 (SPF); próximo a Cardeal Mota, estrada de Pedra dos Escravos, 27.III.1991, bot. e fl., J.R. Pirani et al. CFSC 12115 (HUFU, SPF); Serra do Cipó, estrada para RPPN Brumas do Espinhaço, 1904'11"S 4342'24"W, 2.VII.2015, fl. e fr., F.L. Contro et al. 141 (HUFU); Santana do Pirapama, Distrito de São José da Cachoeira, trilha da captação da Fazenda Toucán Cipó, 17.Il.2007, bot. e fl., V.C. Souza et al. 32529 (ESA, HUFU); Serra do Cipó, próximo à Cardeal Mota, estrada de Pedra dos Escravos, rodovia Belo Horizonte-Conceição do Mato Dentro, para o alto da Cachoeira Véu da Noiva, 27.III.1991, bot. e fl., J.R. Pirani et al. CFSC 12115 (HUFU, SPF); Serra do Cipó, Km 128-129, 15.IV.1950, bot. e fl., A.P. Duarte 2488 (R, RB); Santana do Riacho, RPPN Brumas do Espinhaço e Ermo dos Gerais, 31.I.2013, bot., J.R. Ordones et al. 2178 (BHZB, HUFU).

Acritopappus longifolius ocorre nos estados da Bahia, Ceará, Minas Gerais, Pernambuco, Rio de Janeiro, São Paulo e Sergipe, distribuída em Cerrado e Mata Atlântica. Segundo Bautista (2000) é a espécie mais frequente em Minas Gerais na Serra do Espinhaço. $\mathrm{Na}$ área de estudo pode ser encontrada em campos rupestres e áreas de afloramentos rochosos com árvores esparsas. A espécie é reconhecida pela presença de pecíolos longos (até 3 $\mathrm{cm}$ ), ausência de pápus e capítulos relativamente pequenos (até 19 flores).

É bastante semelhante à Acritopappus irwinii R.M.King \& H.Rob., porém esta apresenta a base das lâminas arredondadas e capítulos grandes com até 50 flores vs base aguda e capítulos pequenos com até 19 flores.

\section{Ageratum L., Sp. PI. 2: 839. 1753.}

Ervas anuais, subarbustos ou arbustos perenes. Ramos herbáceos ou lenhosos, eretos ou decumbentes, pubérulo, piloso, escabro, seríceo, glanduloso ou glabro. Folhas opostas, alternas ou fasciculadas, sésseis ou pecioladas, lâmina ovada, elíptica, lanceolada, lineare, deltoide, orbiculare ou cordada, ápice agudo, arredondado a acuminado, base obtusa, decurrente, cordada, truncada, aguda ou arredondada, margem revoluta, serreada ou plana, crenada, denteada, face adaxial pilosa, escabra, glanduloso-pontoada ou glabra, face abaxial denso a esparsamente pilosa, glanduloso-pontoada, paralelódroma, reticulinérvea ou camptódroma. Capitulescência em corimbos aglomerados ou não, panículas, capítulos pedunculados; invólucro campanulado, hemisférico ou turbinado, 2-3-seriado; brácteas involucrais lanceoladas, oblongolanceoladas, ovadas, oblongas ou espatadas, ápice acuminado, agudo, truncado-cuspidado ou arredondado, ciliado ou glabro. Receptáculo cônico ou convexo, paleáceo ou não. Capítulos com 18-33 flores, corola funeiforme ou tubular, lacínias deltoides. Anteras com apêndice apical presente. Ramos do estilete clavados, papilosos ou mamilosos. Cipsela prismática ou obcônica, carpopódio presente ou não. Pápus coroniforme, paleáceo ou ausente.

Johnson (1971) reconhece 39 espécies no gênero, enquanto King \& Robinson (1987) listam 40 espécies. Os três autores reconhecem que o gênero se distribui pelo México, América Central e América do Sul (Johnson 1971, King \& Robinson 1987). No Brasil são reconhecidas quatro espécies, das quais duas são endêmicas, distribuídas pela Bahia, Goiás, Mato Grosso do Sul, Minas Gerais, Pará, Paraná, Santa Catarina e Rio de Janeiro, sob os domínios da Amazonia, Caatinga, Cerrado, Mata Atlântica, Pampa e Pantanal. Estima-se que o gênero tenha ocorrência por todo o território brasileiro (Nakajima 2015).

Segundo King \& Robinson (1987), Ageratum é reconhecido por apresentar receptáculo cônico, folhas com pontoações glandulosas na face abaxial, carpopódio contorcido e anteras com apêndices grandes. $\mathrm{Na}$ área de estudo foram encontradas três espécies: $A$. conyzoides, $A$. fastigiatum e $A$. myriadenium.

\section{Chave para as espécies de Ageratum}

1. Pápus presente, paleáceo

1'. Pápus ausente.

2. Folhas alternas; receptáculo glabro; ramos do estilete papilosos ............................2.2 A. fastigiatum

2'. Folhas opostas; receptáculo paleáceo; ramos do estilete mamilosos ..........................2.3 A. myriadenium

2.1 Ageratum conyzoides L., Sp. PI. 2: 839. 1753.

Subarbustos, 0,3 m alt. Ramos herbáceos, eretos, cilíndricos, multicostados, hirsutos. Folhas opostas; pecíolos $0,1-0,3 \mathrm{~cm}$ compr., densamente hirsutos; lâmina 0,4-1,9 cm compr., 0,2-1 cm larg., ovada a lanceolada, ápice agudo a curto mucronado, base aguda, arredondada ou obtusa, margem denteada, ambas as faces hirsutas, glandulosopontoadas; camptódroma. Capitulescência em panículas corimbiformes, capítulos com pedúnculo 0,8-4 mm compr., hirsuto; invólucro campanulado, 
eximbricado, 2,6-4,5 mm compr., 1,2-6,4 mm larg., 2seriado; brácteas involucrais 3,1-3,9 mm compr., 0,30,7 mm larg., oblongas, ápice truncado-cuspidado, ciliado ou fimbriado, margem inteira, glabras. Receptáculo cônico, glabro. Capítulo 18 flores; corola tubulosa, 1,2-1,6 mm compr., tricomas glandulares, lacínias $0,2-0,4 \mathrm{~mm}$ compr., papilosas no ápice externamente. Anteras com base arredondada, apêndice apical oblongo, ápice do apêndice arredondado. Ramos do estilete lineares, papilosos, ápice obtuso ou truncado. Cipselas obcônicas, 1,31,65mm compr., $0,35-0,5 \mathrm{~mm}$ larg., glabrescente; carpopódio assimétrico, cilíndrico. Pápus paleáceo, 5 páleas, 1,57-2,3 mm compr.

Material examinado: Brasil, Minas Gerais, Santana do Riacho, PARNA Serra do Cipó, sede do IBAMA, alto da Serra, 19.VIII.1997, bot. e fl., F.A. Vitta 462 (UEC).

Material adicional examinado: Brasil, Minas Gerais, Uberlândia, Estação Ecológica do Panga (EEP), vereda 3, lado esquerdo, 21.V.1999, fl., A.A.A. Barbosa 2076 (HUFU); EEP, vereda 3, meio da vereda, 2.VI.2000, fl., A.A.A. Barbosa s.n. (HUFU 23440).

Ageratum conyzoides é amplamente distribuída no Brasil e no mundo (Johnson, 1971). Dentre as espécies de Ageratum ocorrentes na área de estudo, esta é facilmente distinta pela presença de folhas pecioladas e capítulos com pápus paleáceo vs. folhas sésseis e pápus ausente tanto em $A$. fastigiatum como em $A$. myriadenium. No Brasil é popularmente conhecida como mentrasto (Johnson, 1971).

2.2 Ageratum fastigiatum (Gardner) R.M.King \& H.Rob., Phytologia 24: 114. 1972.

Subarbustos a arbustos, até 1,2 m alt. Ramos herbáceos, eretos, cilíndricos, multicostados, tomentosos a glabrescentes. Folhas alternas, sésseis; lâmina 0,3-7,3 mm compr., 0,1-1,5 cm larg., lanceolada, ápice arredondado ou agudo, base decurrente, margem serreada ou inteira nas folhas mais jovens, ambas as faces glabrescentes, glanduloso-pontoadas, camptódroma. Capitulescência em panículas corimbiformes; capítulos com pedúnculo 0,7-3,4 mm compr., tomentoso, tricomas glandulares; invólucro campanulado, 1,9-5,1 mm compr., 1,6-4,3 $\mathrm{mm}$ larg., 3-seriado; brácteas involucrais 2,3-3,4 mm compr., 0,3-0,6 $\mathrm{mm}$ larg., lanceoladas a oblanceoladas, ápice agudo, face adaxial glandulosoestipitada, estriadas. Receptáculo convexo a levemente cônico, epaleáceo. Capítulo com 20-27 flores; corola tubulosa, tubo 1,6-1,9 mm compr., tricomas glandulares, lacínias $0,4 \mathrm{~mm}$, papilosas. Anteras com apêndice apical ovado, base arredondada. Ramos do estilete lineares, longos, papilosos. Cipsela prismática a obcônica, 1,3-2 mm compr., 0,45 mm larg., 5-costada, glabra carpopódio assimétrico. Pápus ausente.
Material examinado: Brasil, Minas Gerais, Santana do Pirapama, capela de São José, cachoeira do quartel, $18^{\circ} 58^{\prime} 30^{\prime \prime S}$ e $43^{\circ} 46^{\prime} 42^{\prime \prime W}$, 3.X.2010, bot. e fl., D.C. Zappi 2708 (RB); Santana do Pirapama, trilha da Senhorinha, primeiro platô, $18^{\circ} 58^{\prime} 07^{\prime \prime S}$ e $43^{\circ} 45^{\prime} 08^{\prime \prime W}, 8 . X .2009$, bot. e fl., D.C. Zappi 1883 (RB); Serra do Cipó, estrada para

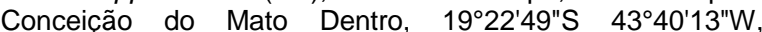
29.VI.2015, bot. e fl., F.L. Contro et al. 64 (HUFU); Santana do Riacho, Fazenda Cachoeira da Capivara, 4.VII.1996, bot. e fl., V.C. Souza et al. 11643 (ESA, HUFU); Estrada para Conceição do Mato Dentro, próximo à estatua do Juquinha, 17.XII.2014, bot. e fl., F.L. Contro 25 \& D. Marques (HUFU); Congonhas do Norte, trilha entre Retiro do Barbaro e Fazenda do Sr. José Correia (Serra Talhada), 24.IV.1982, bot. e fl., M.C.E. Magalhães CFSC 8470 (HUFU, SPF); Jaboticatubas, km 122, próximo à pasto e roça, 8.III.1985, bot. e fl., T.M. Lewinsohn \& R.P. Martins s.n. (UEC 43734); Jaboticatubas, km 110, 6.III.1985, bot. e fl., T.M. Lewinsohn \& R.P. Martins s.n. (UEC 44610); Santana do Riacho, 15.XII.1995, fl., P. Prado et al. PIC 95810 (UEC); Santana do Riacho, próximo ao Palácio, km 135, 25.IV.1978, fl. e fr., H.C. Lima 391 (UEC); Santana do Riacho, km 132 da rodovia Belo Horizonte-Conceição do Mato Dentro, 1.I.1981, fl., N.M. Castro \& M.G. Sajo CFSC 6492 (UEC); Jaboticatubas, ao longo da rodovia Lagoa Santa-Conceição do Mato DentroDiamantina, 21.VIII.1972, bot. e fl., A.B. Joly \& J. Semir (UEC 1747); Jaboticatubas, ao longo da rodovia Lagoa SantaConceição do mato Dentro-Diamantina, 21.VIII.1972, bot. e fl., A.B. Joly \& J. Semir (UEC 1747); Santana do Riacho, rodovia Belo Horizonte-Conceição do Mato Dentro, km 117, 21.II.1984, bot. e fl., M. Venturelli \& M.C.E. Amaral s.n. (HRCB s.n., HUFU 3547)

Ageratum fastigiatum é amplamente distribuída no Brasil (Nakajima, 2001). Pode ser reconhecida por apresentar suas folhas quase em fascículos e brácteas involucrais com tricomas glandulares. Diferencia-se de Ageratum myriadenium, espécie mais próxima, pela presença de folhas alternas glabrescentes e glanduloso-pontoadas vs. folhas opostas glabras.

2.3 Ageratum myriadenium (Sch.Bip. ex Baker) R.M.King \& H.Rob., Phytologia 24: 115. 1972.

Fig. 1D-F

Subarbustos, 0,4 m alt. Ramos herbáceos, eretos, cilíndricos, multicostados, seríceos, glanduloso-pontoados. Folhas opostas, sésseis; lâmina 2,4-5,2 cm compr., $0,3-1,6 \mathrm{~cm}$ larg., lanceolada, ápice agudo, base decorrente, margem serreada, ambas faces glabras, glanduloso-pontoadas, camptódroma. Capitulescência em panículas corimbiformes; capítulos com pedúnculo 1,3-5,3 mm, seríceo, glanduloso-pontoado; invólucro campanulado, 1,8-3,6 mm compr., 2,7-5,4 mm larg., 3-seriado; brácteas mais externas 2,7-3,5 mm compr., 1-1,3 mm larg., lanceoladas, ápice acuminado, margem inteira, ciliada, face adaxial serícea, glanduloso-pontoada, brácteas internas 3,3-3,5 mm compr., 0,7-1 mm larg., lanceoladas, ápice acuminado, margem inteira, ciliada, face adaxial serícea, glanduloso-pontoada. Receptáculo convexo, paleáceo, páleas 2,4-3 mm 
compr., 0,4-0,5 mm larg., lanceoladas, ápice longo acuminado ou apiculado, margem inteira, ciliada, glanduloso-pontoadas. Capítulos com até 33 flores; corola tubulosa, tubo $0,4-0,5 \mathrm{~mm}$ compr., tricomas glandulares, limbo 0,9-1,1 $\mathrm{mm}$ compr., glandulosopontoado, lacínias $0,2-0,4 \mathrm{~mm}$ compr., mamilosas externamente. Anteras com base arredondada, apêndice apical ovado. Ramos do estilete lineares, mamilosos. Cipsela obcônica, 1,1-1,9 mm compr., 0,2-0,6 mm larg., glabras; carpopódio inconspícuo. Pápus ausente.

Material examinado: Brasil, Minas Gerais, Santana do Riacho, RPPN Brumas do Espinhaço e Ermo dos Gerais, 14.V.2012, bot. e fl., I.R. Andrade et al. 326 (BHZB, HUFU); Estrada para Conceição do Mato Dentro, aproximadamente

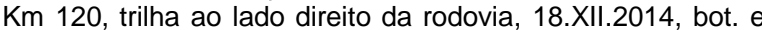
fl., F.L. Contro 35 \& D. Marques (HUFU); Jaboticatubas, Serra do Cipó, Km 137, 22.III.1940, bot. e fl., Mello Barreto 10781 (BHCB, BHMH).

Ageratum myriadenium ocorre na Bahia, Goiás, Minas Gerais e Rio de Janeiro, no domínio do Cerrado. $\mathrm{Na}$ área de estudo pode ser encontrada em bordas de estradas. A espécie é reconhecida por apresentar suas folhas opostas e sésseis longamente decorrentes na base, com aparência de pecíolo e pela presença de cipselas rostradas.

\section{Ayapana Spach, Hist. Nat. Vég. 10: 290. 1841.}

Ervas a subarbustos, eretos, sem ramos na parte vegetativa ou com esta ramificada basalmente. Ramos cilíndricos a hexagonais. Folhas opostas, sésseis; lâmina ovada, elíptica a lanceolada, margem inteira a serreada, base alada ou não, paralelódroma, craspedódroma ou camptódroma. Capitulescência em panículas laxas, ramos corimbosos laxos ou densos; capítulos pedunculados ou sésseis; invólucro campanulado, subimbricado, 4-5-seriado, persistente, brácteas caducas na maturidade. Receptáculo plano a convexo, glabro. Capítulos com 5-45 flores; corola tubulosa ou funeiforme, branca ou rosa-intenso, glabra, lacínias triangulares, glandulosas. Anteras com apêndices triangulares, oblongos ou lanceolados, colar delgado. Ramos do estilete filiformes ou recurvados e afilados, papilosos, base não alargada. Cipselas prismáticas ou obcônicas, setosas nas costas; carpopódio distinto, assimétrico. Pápus cerdoso, persistente, cerdas com ápice pontiagudo.

O gênero Ayapana foi estabelecido por Spach (1841) baseando-se nas longas papilas dos ramos do estilete e camada basal das células do carpopódio espessadas (King \& Robinson, 1987). Distribuído pelas Américas do Sul e Central, o gênero apresenta 14 espécies (King \& Robinson, 1987), sendo que quatro destas ocorrem no Brasil, em todas as regiões, com exceção do sul do país (Hattori, 2015). Na área de estudo foi encontrada somente uma espécie do gênero.
3.1 Ayapana amygdalina (Lam.) R.M.King \& H.Rob., Phytologia 20 (3): 211. 1970.

Fig. 1G-I

Ervas a subarbustos, $0,4 \mathrm{~m}$ alt. Ramos cilíndricos, multicostados, setosos, tricomas glandulares próximo à capitulescência. Folhas opostas, sésseis; lâmina 1,7-9,4 cm compr, 0,5-2 $\mathrm{cm}$ larg., lanceolada, ápice curto mucronado, base atenuada ou decurrente, margem serreada, face adaxial serícea-escabra, glanduloso-pontoada, face abaxial seríceo-tomentosa, escabra, glandulosopontoada, camptódroma. Capitulescência em panículas corimbiformes; capítulos com pedúnculo 1-6,7 $\mathrm{mm}$, tricomas glandulares; invólucro campanulado, 3,9-8,3 mm compr., 2,1-9,6 mm larg., 4-5-seriado; brácteas externas 1,9-4,7 mm compr., 0,4-0,5 mm larg., triangulares a lanceoladas, ápice agudo, margem inteira, tricomas glandulares, brácteas medianas 4,1-6,2 mm compr., 0,6-0,62 mm larg., lanceoladas, ápice longo acuminado, margem inteira, tricomas glandulares brácteas internas 6,39,3 mm compr, 0,4-0,7 mm larg., linear-lanceoladas, ápice longo acuminado, margem inteira, tricomas glandulares. Receptáculo plano, glabro. Capítulo com 40-45 flores; corola tubulosa, tubo 4,7-6,3 $\mathrm{mm}$ compr., glabro, lacínias 0,8 mm compr., esparsamente glanduloso-pontoadas na face externa. Anteras com base arredondada, apêndice apical lanceolado. Ramos do estilete lineares, tricomas glandulares. Cipsela obcônica, 0,8-1,8 mm compr., 0,2-0,3 mm diâm., glabra; carpopódio assimétrico, anelar. Pápus cerdoso, 1-seriado, 4,7$5,7 \mathrm{~mm}$ compr.

Material examinado: Brasil, Minas Gerais, Santana do Riacho, Fazenda Palácio, próximo ao campo de Paepalanthus bromelioides; 1.IX.1991, fl., J.R.Pirani et al. CFSC 12714 (HUFU, SPF); Serra da Bandeirinha, próximo à casa do IBDF, 9.IX.1987, fl., C. Kameyama et al. CFSC 10510 (HUFU, SPF); Santana do Riacho, RPPN Brumas do Espinhaço e Ermo dos Gerais, 11.IX.2012, fl., C.A. Ferreira Junior et al. 571 (BHZB, HUFU); PARNA Serra do Cipó, Serra da Bandeirinha, 9.IX.1987, bot. e fl., C. Kameyama et al. CFSC 10510 (HUFU, SPF); Serra do Cipó, Fazenda Palacio próximo ao campo de Paepalanthus bromelioides, 1.IX.1991, bot. e fl., J.R. Pirani et al. CFSC 12714 (HUFU, SPF).

Ayapana amygdalina é amplamente distribuída no Brasil, não ocorrendo apenas na região sul do país. Na área de estudo ocorre em campo rupestre e formações campestres. A espécie apresenta forma bastante variável (Esteves, 2001), mas possui algumas características reconhecíveis, como a presença de tricomas glandulares em toda a planta, inclusive nos ramos do estilete. Nakajima (2001) cita suas flores vermelho-púrpureas, ramos do estilete filiformes e pápus alvo, como características diagnósticas da espécie. 


\section{Campuloclinium DC., Prodr. 5: 136. 1836.}

Ervas, subarbustos ou arbustos eretos. Ramos cilíndricos, estriados, hirsutos. Folhas opostas ou alternas, sésseis ou com pecíolos curto-alados; lâmina ovada, elíptica, estreito-elíptica ou estreitooblonga, as mais novas lanceoladas. Capitulescência corimbosa, poucos ou muitos capítulos; invólucro eximbricado a fracamente subimbricado, 2-3 séries. Receptáculo hemisférico a cônico, glabro. Capitulo com 30-100 flores; corola tubulosa, rósea, lilás ou roxa, estreito-funeiforme, lacínias triangulares, mais longas do que largas, papilosas. Anteras com apêndices oblongos. Ramos do estilete lineares, base não alargada, pouco ou muitos tricomas, mamilosos ou papilosos. Cipselas prismáticas, base estipitada, pouco ou muitas glândulas, carpopódio anelar a curtocilindrico. Pápus unisseriado, cerdas com ápice subagudo a agudo.

Campuloclinium foi estabelecido com base em seu repectáculo hemisférico a cônico, glabro (King \& Robinson, 1987). São reconhecidas 24 espécies no gênero, com distribuição quase restrita ao Brasil, com poucas espécies ocorrentes no Paraguai e noroeste da Argentina (King \& Robinson, 1987).

No Brasil existem 15 espécies, das quais 11 são endêmicas, distribuídas pela Amazônia, Caatinga, Cerrado e Mata Atlântica (Ferreira, 2015). Na área de estudo foi encontrada somente uma espécie.

4.1 Campuloclinium riedelii (Baker) R.M.King \& H.Rob., Phytologia 24: 172. 1972.

Fig. 1J-K

Subarbusto, 0,2-0,5 m alt. Ramos cilíndricos, multicostados, setosos, glanduloso-pontoados. Folhas alternas, sésseis; lâmina 0,6-2,6 cm compr., 0,2-1,5 $\mathrm{cm}$ larg., elípticas, estreito-elípticas, as mais novas lanceoladas, ápice curto mucronado a obtuso, base aguda e decorrente, margem inteira, às vezes levemente revoluta, ambas faces glandulosopontoadas, densamente setosas na nervura mediana, esparso-setosa nas nervuras lateais; hifódroma. Capitulescência em cimas ou racemos e, às vezes, racemos corimbosos; capítulos com pedúnculo 4,5$32,3 \mathrm{~mm}$ compr., densamente setoso-tomentoso, glanduloso-pontoado; invólucro campanulado a largocampanulado, 7,3-10,7 mm compr., 4,5-13,7 mm larg., brácteas involucrais 6,2-10,2 mm compr., 1,4$1,85 \mathrm{~mm}$ larg., lanceoladas, ápice caudado, margem inteira, face adaxial setosa. Receptáculo levemente cônico, glabro. Capítulo com 36-37 flores; corola tubulosa, tubo 3,3-3,4 $\mathrm{mm}$ compr., tricomas glandulares, limbo indiferenciado, lacínias 0,9-1,3 mm compr., glanduloso-pontoadas externamente, às vezes com estrias ou manchas marrons externamente. Anteras com base sagitada, apêndice apical oblongo, ápice do apêndice emarginado ou obtuso. Ramos do estilete lineares, mamilosos, base do estilete pilosa. Cipsela prismática, $1,9-4 \mathrm{~mm}$ compr., $0,8-1,1 \mathrm{~mm}$ larg., tricomas glandulares; carpopódio simétrico, anelar. Pápus cerdoso, 1-seriado, 4,3-4,7 mm compr.

Material examinado: Brasil, Minas Gerais, Santana do Riacho, Alto do Palácio, próximo à um campo queimado de Actionocephalus, 17.XII.2014, bot. e fl., F.L. Contro 22 \& $D$. Marques (HUFU); RPPN Brumas do Espinhaço e Ermo dos Gerais, 29.XI.2012, fl., J. Ordones et al. 310 (BHZB, HUFU).

Campuloclinium riedelii distribui-se pelos estados de Goiás, Mato Grosso, Minas Gerais, Paraná, Rio Grande do Sul e São Paulo, em áreas de Cerrado. $\mathrm{Na}$ área de estudo pode ser encontrada em áreas de campo rupestre, geralmente após queimadas. É bastante similar à Campuloclinium megacephalum (Mart. ex. Baker) R.M.King \& Rob. pelo invólucro largo-campanulado, folhas alternas e sésseis e capitulescência em cimas terminais, porém difere da mesma por apresentar a base do estilete densamente pilosa e capítulos pequenos (até 40 flores) vs. base do estilete esparso-pilosa e capítulos grandes (70-80 flores).

\section{Chromolaena DC., Prodr. 5: 133. 1836.}

Ervas, subarbustos ou arbustos perenes, eretos ou pouco decumbentes. Ramos cilíndricos a hexagonais, pubescentes. Folhas geralmente opostas, alternas, raramente verticiladas, sésseis ou pecioladas; lâmina ovada, lanceolada, elíptica, às vezes lineares, margem inteira, serreada; paralelódroma, peninérvea, camptódroma ou com nervuras terciárias densamente reticuladas. Capitulescência tirsoide a candelabriforme, ramos laxo a densamente corimbiformes; capítulos geralmente pedunculados; invólucro densamente imbricado, 3-6seriado, persistente, às vezes caduco; brácteas involucrais ovadas a lanceoladas, geralmente com ápice colorido. Receptáculo plano a levemente convexo, glabro, raramente paleáceo, glabro. Capitulo com 6-75 flores; corola branca, lilás, com poucas ou muitas glândulas, lacínias oblongas a ovadas, mais longas do que largas, geralmente papilosas internamente. Anteras com apêndice oblongo, lanceolado, agudo, triangular, ovado, mais longo do que largo. Ramos do estilete lineares ou espessados no ápice, mamilosos ou papilosos, base do estilete não alargada, glabra. Cipsela prismática ou obcônica, costa setosa, às vezes glandulosa; carpopódio distinto, curto-cilíndrico ou estreito. Pápus unisseriado, cerdas com ápice agudo.

Chromolaena apresenta 165 espécies distribuídas na America do Sul, norte do México e sudeste dos Estados Unidos (King \& Robinson, 1987). No Brasil são conhecidas 70 espécies, das quais 45 são endêmicas, distribuídas em todo o território nacional, ocorrendo na Amazônia, Caatinga, Cerrado, Mata Atlântica, Pampa e Pantanal. O gênero é um dos maiores de Eupatorieae e difere de Praxelis Cass., 
Flora da Serra do Cipó, Minas Gerais: Asteraceae - Eupatorieae

pela presença de cipselas prismáticas e 5-costadas, carpopódio simétrico e receptáculo não cônico (King \& Robinson, 1987).

Chromolaena DC. foi reestabelecido por King \& Robinson (1987), como gênero distinto com base em espécies de Osmia Sch.Bip. e Eupatorium sect.
Cylindrocephala DC., cujo reconhecimento se dava por meio da presença de base do estilete glabra e não alargada, folhas opostas, poucos tricomas e carpopódio pequeno e distinto (King \& Robinson, 1971). Na área de estudo foram encontradas 20 espécies deste gênero.

\section{Chave para as espécies de Chromolaena}

1. Folhas alternas.

2. Capítulos pequenos com até 11 flores.

3. Folhas sésseis, face adaxial glabrescente

3'. Folhas pecioladas, face adaxial escabra ou serícea.

5.18 C. stachyophylla

4. Capítulos com 4 flores; cerdas do pápus com ápice não espessado

5.5 C. campestris

4'. Capítulos com 11 flores; cerdas do pápus com ápice espessado

2'. Capítulos grandes com 12-30 flores.

5. Capitulescência em racemos; receptáculo paleáceo

5'. Capitulescência em panículas; receptáculo glabro.

6. Brácteas involucrais com ápice truncado-cuspidado; lacínias glanduloso-pontoadas externamente

6'. Brácteas involucrais com ápice agudo ou acuminado; lacínias pilosas externamente 5.13 C. pedalis Folhas opostas.

7. Folhas com base sagitada; receptáculo paleáceo

7'. Folhas com base atenuada ou decorrente; receptáculo epaleceo, piloso ou glabro

8. Folhas com venação peninérvea

5.4 C. barrosoae

8'. Folhas com venação camptódroma, acródroma basal ou reticulada (nervuras terciárias), raramente hifódromas.

9. Capitulo solitário, terminal.

10. Plantas eretas; capítulos com 10-17 flores; cerdas do pápus alvas

10'. Plantas decumbentes; capítulos com até 67 flores; cerdas do pápus com ápice lilás

5.2 C. ascendens

9'. Capítulos em capitulescência de dicásio, panículas ou tirsos.

11. Lâminas foliares hifódromas

11'. Lâminas foliares paralelódromas, camptódromas ou reticuladas.

12. Invólucro estreito-campanulado.

13. Capitulescência em panículas de dicásio; lacínias da corola mamilosos internamente

13'. Capitulescência em dicásio; lacínias da corola papilosas internamente

5.20 C. vindex

2'. Invólucro cilíndrico.

14. Brácteas involucrais externas com ápice agudo.

15. Folhas com venação acródroma basal; cipsela não comprimida.

16. Ramos e capitulescências patentes; receptáculo convexo; corola com tricomas glandulares ...................................................................................5.12 C. oxylepis

16'. Ramos e capitulescências não patentes; receptáculo plano; corola glabra ..........5.17 C. squalida

15'. Folhas com venação camptódroma.

17. Cipselas comprimidas

5.3 C. barbacensis

17'. Cispelas não comprimidas

5.1 C. adenolepis

14'. Brácteas involucrais externas ápice arredondado, truncado, obtuso, acuminado ou curto-mucronado.

18. Capitulescência em tirsos; receptáculo plano .

5.15 C. pungens

18'. Capitulescência em panículas ou dicásios, receptáculo convexo.

19. Lâminas foliares com a face adaxial hirsuta; capitulescência em dicásios; brácteas involucrais externas com ápice obtuso ou mucronado

19'. Lâminas foliares com a face adaxial glabra; capitulescência em panículas; brácteas involucrais externas com ápice agudo

5.1 Chromolaena adenolepis (Sch.Bip. ex Baker) R.M.King \& H.Rob., Phytologia 20: 198. 1970.

Erva, $0,1-0,4 \mathrm{~m}$ alt. Ramos cilíndricos, hirsutos, glanduloso-pontoados. Folhas opostas; pecíolo 1-1,4 $\mathrm{mm}$ compr., hirsuto, glandulosopontoado; lâminas $0,5-2,2 \mathrm{~cm}$ compr., $0,2-1,1 \mathrm{~cm}$ larg., elípticas ou lanceoladas, ápice agudo ou arredondado, base aguda ou atenuada, margem serreada, face adaxial esparsamente hirsuta, face abaxial glanduloso-pontoada, esparsamente hirsuta na nervura principal, camptódroma. Capitulescência em panículas corimbiformes ou dicásios terminais; capítulos com pedúnculo 1,4-11,8 mm compr., hirsuto, glanduloso-pontoado; invólucro cilíndrico, $5-8,3 \mathrm{~mm}$ compr., 2,4-5,7 mm larg., 3-5-seriado; brácteas 3,1$6,7 \mathrm{~mm}$ compr., 1,1-1,7 $\mathrm{mm}$ larg., as externas oblongo-lanceoladas ou ovadas, ápice agudo, margem inteira, ciliada na metade superior, arroxeada, face adaxial glanduloso-pontoada no terço superior, as 
internas lanceoladas, ápice cuspidado, esquarroso, margem inteira, ciliada, arroxeada, face adaxial glanduloso-pontoada no terço superior. Receptáculo convexo, glabro. Capítulos com 18-24 flores; corola com tubo 3,3 mm compr., esparsamente glandulosopontoado, lacínias 0,4 $\mathrm{mm}$ compr., papilosas, arroxeadas, glanduloso-pontoada. Anteras com apêndice apical lanceolado, base arredondada. Ramos do estilete lineares, ápice obtuso, papilosos. Cipsela obcônica ou prismática, 2-2,3 mm compr., 0,5-0,6 mm diâm., glabra, costas ciliadas; carpopódio simétrico, anelar. Pápus 3,6-4 mm compr.

Material examinado: Minas Gerais, Santana do Riacho, km 118 rodovia Belo Horizonte - Conceição do Mato Dentro, 19¹5'38"S e 43³3'10.3"W, 05.III.2002, fl., J.R. Pirani et al. 5020 (SPF); Santana do Riacho, 16.Il.1982, bot. e fl., W. Mantovani et al. CFSC 7768 (SPF); Serra do Cipó, 17.II.1972, fl., W.R. Anderson et al. s.n. (RB 163266).

Chromolaena adenolepis encontra-se distribuída pelos estados de Minas Gerais e Paraná. $\mathrm{Na}$ área de estudo pode ser encontrada em campo rupestre. Esta espécie pode ser reconhecida por apresentar suas brácteas internas quase obdeltoides, alargando-se próximo ao ápice, quase em forma de losango.

5.2 Chromolaena ascendens (Sch. Bip. ex Baker) R.M.King \& H.Rob., Phytologia 20: 199. 1970.

Erva ereta, ca. 0,35 m alt. Ramo cilíndrico, multicostado, seríceo. Folhas opostas; sésseis, lâmina 0,9-2,2 cm compr., 0,3-0,8 cm larg., lanceolada, ápice arredondado, base decorrente, margem serreada, sericea, ambas faces glanduloso-pontoadas, paralelódroma. Capítulo terminal, solitário; invólucro campanulado, 8,6 mm compr., 6,5 mm larg., 6-seriado; brácteas involucrais com margem ciliada, face adaxial glanduloso-pontoada no terço superior, as externas, 2,5-2,9 mm compr., ca. 1,14 mm larg., lanceoladas, ápice agudo, as medianas, 4,8-5,9 mm compr., 2,22,4 mm larg., oblongas, ápice obtuso, as internas 8,3$8,8 \mathrm{~mm}$ compr., 1,1-1,3 mm larg., oblongas, ápice obtuso, margem ciliada, glanduloso-pontoadas no terço superior da face adaxial. Receptáculo convexo, glabro. Capítulo com 10-17 flores; corola com tubo até 3,5 mm compr., glabras, lacínias 0,5 mm compr., tricomas glandulares. Anteras com base sagitada, apêndice apical lanceolado. Ramos do estilete lineares, mamilosos. Cipselas prismática, 2,2-2,7 mm compr., 0,6-0,8 mm diâm., glabras, costas ciliadas; carpopódio assimétrico, anelar. Pápus 5,3-5,8 mm compr., alvo.

Material examinado: Minas Gerais, Santana do Pirapama, Serra do Cipó (Serra da Lapa), Distrito de São José da Cachoeira, Trilha da Senhorinha, $18.9422^{\circ} \mathrm{S}$ 43.7498W, 19.II.2007, fl., V.C. Souza et al. 32825 (ESA, SPF); RPPN Brumas do Espinhaço, estrada para a sede, aproximadamente $400 \mathrm{~m}$ da porteira, 3.VII.2015, fl. e fr., F.L. Contro et. al. 157 (HUFU).
Chromolaena ascendens ocorre no Mato Grosso do Sul, Minas Gerais, Paraná, Rio Grande do Sul, Rio de Janeiro, Santa Catarina e São Paulo, em Cerrado e Mata Atlântica. Na área de estudo ocorre em campos limpos com afloramentos rochosos. A espécie é mais facilmente reconhecida por ser uma das poucas, na área de estudo, a apresentar capítulo terminal e solitário com invólucro campanulado.

Às vezes pode ser confundida com $C$. decumbens pelo hábito herbáceo e capitulescência solitária, contudo esta apresenta-se como erva decumbente e suas lâminas foliares são elípticas e hirsutas (vs. erva ereta e lâminas foliares lanceoladas e seríceas).

5.3 Chromolaena barbacensis (Hieron.) R.M.King \& H.Rob., Phytologia 20: 199. 1970.

Subarbustos, 0,6-1 m alt. Ramos cilíndricos, multicostados, densamente hirsuto-setosos, glanduloso-pontoados. Folhas opostas; pecíolo 0,34,3 mm compr., densamente hirsuto-setoso, glanduloso-pontoado; lâmina 0,3-2,9 cm compr., 0,3$1,6 \mathrm{~cm}$ larg., ovada ou elíptica, ápice agudo, às vezes, curto mucronado, base aguda, margem denteada na metade superior ou inteira nas folhas jovens, face adaxial escabra, esparsamente glanduloso-pontoada, face abaxial densamente hirsuto-tomentosa, glanduloso-pontoada, camptódroma, fortemente reticulada. Capitulescência em panículas corimbiformes, capítulos com pedúnculo $0,8-3,1 \mathrm{~mm}$ compr., hirsuto, esparsamente glanduloso-pontoado; invólucro cilíndrico, 2-12,3 mm compr., 1,7-5,1 mm larg., 3-7-seriado; brácteas involucrais com ápice agudo, as externas 0,9-1,6 mm compr., 1,3-1,4 mm larg., ovadas a triangulares, ápice às vezes castanho ou levemente arroxeado, margem inteira, as medianas 3,5-5,7 mm compr., 1,8-1,9 mm larg., oblongolanceoladas, ápice curto ciliado, castanho ou levemente arroxeado, margem fimbriada, internas 6,912,1 mm compr., 0,9-1,1 mm larg., lineares, ápice às vezes ciliado, margem fimbriada. Receptáculo plano, glabro. Capítulo com 29 flores; corola com tubo 4,34,8 mm compr., limbo indiferenciado, glabro, lacínias ca. $\quad 0,6 \quad \mathrm{~mm}$ compr., glanduloso-pontoadas externamente. Anteras com base curto sagitada ou cordada, apêndice apical lanceolado, agudo. Ramos do estilete lineares, papilosos; estilopódio cilíndrico. Cipsela comprimida, 2-2,7 mm compr., 0,2-0,4 mm diâm., glabra; carpopódio simétrico, anelar. Pápus 4,4-4,8 mm compr., cerdas levemente espessadas no ápice.

Material examinado: Minas Gerais, Santana do Riacho, rodovia Belo Horizonte-Conceição do Mato Dentro km 117, 19.IV.1981, bot., fl. e fr., A. Furlan et al. CFSC 7221 (R, SPF); Santana do Riacho, Serra da Lapinha, ca. $50 \mathrm{Km}$ da rodovia Belo Horizonte-Conceição do Mato Dentro, 27.III.1991, bot. e fl., J.R. Pirani et al. CFSC 12222 (R, SPF); Santana do Riacho, rodovia Belo Horizonte-Conceição do Mato Dentro, 4.V.1986, bot., fl. e fr., J.R. Pirani et al. CFSC 9793 (SPF); Estrada para Conceição do Mato Dentro, aprox. 
km 123, 30.VI.2015, bot. e fl., F.L. Contro et al. 88 (HUFU); Serra do Cipó, perto do Hotel Palácio, 5.IV.1951, bot., fl. e fr., G.A. Black \& M. Magalhães 51-11931 (RB).

Chromolaena barbacensis ocorre em Minas Gerais, Rio de Janeiro e São Paulo, em Caatinga, Cerrado e Mata Atlântica. Na área de estudo pode ser encontrada em campo rupestre. Almeida (2008) aproxima esta espécie de $C$. cylindrocephala (Sch.Bip. ex Baker) R.M.King \& H.Rob. pelo invólucro menor e receptáculo glabro, enquanto Nakajima (2001) compara esta a C. minasgeraensis (Hieron.) R.M.King \& H.Rob.; no entanto, esta apresenta folhas membranáceas, elípticas a lanceoladas e brácteas involucrais glabras vs. folhas ovadas a elípticas e brácteas hirsutas.

Duas características marcantes da espécie são a cipsela comprimida e venação fortemente reticulada nas nervuras terciárias, não encontradas em outras espécies do gênero na área de estudo.

5.4 Chromolaena barrosoae R.M.King \& H.Rob., Phytologia 47: 232. 1980.

Ervas, $0,5 \mathrm{~m}$ alt. Ramos cilíndricos, multicostados, seríceo-setosos. Folhas alternas, distintamente espiraladas, sésseis; lâmina 0,4-2,2 cm compr., 0,2-0,3 cm larg., lanceolada, ápice agudo, base decorrente ou sagitada, margem com 1 dente no terço inferior, revoluta, face adaxial esparsamente seríceo-setosa, face abaxial glanduloso-pontoada, seríceo-setosa na nervura principal, camptódroma. Capitulescência em racemos; capítulos com pedúnculo 1,7-34,8 $\mathrm{mm}$ compr., arroxeado, esparsamente seríceo a glabrescente; invólucro campanulado, 5,4-7,5 mm compr., 3,9-4,7 mm larg., 4-5-seriado; brácteas involucrais com margem ciliada, porção superior serícea, face adaxial glandulosopontoada, as externas 2,5-2,7 mm compr., 1,4-2,1 $\mathrm{mm}$ larg., ovadas, ápice curtamente cuspidado, as medianas 3,3-4,1 mm compr., 1,4-1,9 mm larg., ovadas, as internas 4,5-4,7 mm compr., 1,3-1,32 mm larg., lanceoladas, ápice curtamente cuspidado. Receptáculo plano, páleas 6,2-6,9 mm compr., 0,3$0,7 \mathrm{~mm}$ larg., linear-lanceoladas, ápice curtamente cuspidado, seríceo. Capítulo com 28 flores; corola com tubo 2,7-3,2 mm compr., lacínias 0,8-1,1 mm compr., glanduloso-pontoadas externamente, mamilosas interna e externamente nas margens. Anteras com base curtamente sagitada, apêndice apical lanceolado. Ramos do estilete lineares, ápice arredondado, mamilosos. Cipsela prismática, 1,7-2 mm compr., 0,4$0,9 \mathrm{~mm}$ larg., glabra, costas ciliadas; carpopódio indistinto ou assimétrico, anelar. Pápus 2,9-4,4 mm compr.

Material examinado: Minas Gerais, córrego Duas Pontinhas, $19^{\circ} 18^{\prime} \mathrm{S}$ e $43^{\circ} 34^{\prime} \mathrm{W}$, bot. e fl., 24.III.1989, R. MelloSilva \& J.R. Pirani CFSC 11310 (R, SPF, UEC).

Material adicional examinado: Brasil, Minas Gerais, Diamantina, Parque Estadual do Biribiri, antes da descida da Serra do Gombô, 23.II.2010, fl., I.M.Franco 35 (HUFU).
Chromolaena barrosoae é endêmica de Minas Gerais. Na área de estudo pode ser encontrada em campos rupestres. A espécie pode ser reconhecida por apresentar suas folhas alternas e sésseis, lâmina lanceolada com base geralmente sagitada, margem com um dente no terço inferior e receptáculo paleáceo.

\subsection{Chromolaena campestris (DC.) R.M.King \&} H.Rob., Phytologia 20: 200. 1970.

Ervas, ca. 0,4 $\mathrm{m}$ alt. Ramo cilíndrico, multicostado, hirsuto. Folhas alternas; pecíolo 2-5,7 $\mathrm{mm}$ compr., densamente hirsuto; lâminas $0,47-3 \mathrm{~cm}$ compr., 0,2-1,5 cm larg., elípticas ou lanceoladas, ápice curto mucronado, base aguda, margem serreada, face adaxial escabra, face abaxial densamente setosa, glanduloso-pontoada; actinódromas. Capitulescência em corimbos, capítulos sésseis; invólucro cilíndrico, 5,8-7,7 mm compr., 2,1-4 $\mathrm{mm}$ larg., 3-seriado; brácteas involucrais com ápice truncado, ciliado, na face adaxial glanduloso-pontoado e hirsuto no terço superior, as externas 3,7-3,9 mm compr., 1,2-1,4 mm larg., ovadas ou loanceoladas, as internas 6,1-6,2 mm compr., 1,3-1,5 mm larg., oblongas, ápice arroxeado. Receptáculo plano, glabro. Capítulo com 4 flores; corola com tubo 4,9-5 mm compr., glanduloso-pontoado, lacínias 0,9-1,1 mm compr., mamilosas internamente. Anteras com base sagitada, apêndice apical lanceolado. Ramos do estilete lineares, mamilosos. Cipsela prismática, 3-3,3 mm compr., 0,9-1 mm diâm., glabra, costas ciliadas; carpopódio simétrico, anelar. Pápus 4,7-5,1 mm compr.

Material examinado: Minas Gerais, Santana do Riacho, RPPN Brumas do Espinhaço e Ermo dos Gerais, 29.XI.2012, bot., fl. e fr., F.M. Fernandes et al. 311 (BHZB, HUFU); Santana do Riacho, RPPN Brumas do Espinhaço e Ermo dos Gerais, 28.XI.2012, bot., fl. e fr., C.A. Ferreira Junior et al. 764 (BHZB, HUFU); Santana do Riacho, RPPN Brumas do Espinhaço e Ermo dos Gerais, 28.XI.2012, bot., fl. e fr., C.A. Ferreira Junior et al. 664 (BHZB, HUFU); Serra do Cipó, km 125 da rodovia Belo Horizonte-Conceição do Mato Dentro, elevação atrás da estatua do Velho Juca, além do córrego, 7.XII.1991, bot. e fl., J.R. Pirani et al. CFSC 12845 (HUFU, SPF); Estrada de Lapinha da Serra para RPPN Brumas do Espinhaço, 1903'59"S 4342'24"W, 2.VII.2015, fl., F.L. Contro et al. 138 (HUFU).

Chromolaena campestris ocorre nos estados de Minas Gerais e São Paulo, em áreas de Cerrado. $\mathrm{Na}$ área de estudo pode ser encontrada em campo rupestre. A espécie é facilmente reconhecida por apresentar suas brácteas involucrais com ápice truncado e arroxeado e folhas alternas.

Pode ser confundida com C. stachyophylla pela presença de folhas alternas, contudo esta possui suas brácteas com ápice acuminado e ramos do estilete papilosos (vs. brácteas com ápice truncado e ramos do estilete mamilosos). 
5.6 Chromolaena chaseae (B.L.Rob.) R.M.King \& H.Rob., Phytologia 20: 200. 1970

Arbustos, $0,8 \mathrm{~m}$ alt. Ramo cilíndrico, multicostado, seríceo-tomentoso, glandulosopontoado. Folhas opostas; pecíolo 2,9-12,6 mm compr., seríceo-tomentoso, glanduloso-pontoado; lâminas $0,7-6,8 \mathrm{~cm}$ compr., $0,2-3,4 \mathrm{~cm}$ larg., ovadas ou lanceoladas, ápice mucronado, base aguda, margem serreada, face adaxial serícea, glandulosopontoada, face abaxial seríceo-tomentosa, glandulosopontoada; paralelódromas. Capitulescência em dicásios, capítulos com pedúnculo 1,4-8,8 mm compr., seríceo-tomentoso, glanduloso-pontoado; invólucro cilíndrico, 7,4-10 mm compr., 3,1-3,7 mm larg., 4-7seriado; brácteas externas 2,4-3 mm compr., 1,5-1,6 $\mathrm{mm}$ larg., ovadas, oblongo-lanceoladas, ápice mucronado ou obtuso, ciliado, margem inteira, glabras, brácteas medianas $6-6,7 \mathrm{~mm}$ compr., $1,4-1,8 \mathrm{~mm}$ larg., ápice agudo, raramente mucronado, ciliado, margem inteira, glabras, brácteas internas 8,2-9,8 mm compr., 1,1-1,2 mm larg., oblongas, ápice agudo, margem ciliado, glabras. Receptáculo convexo, glabro. Capítulo com 24 flores; corola com tubo 3,9-4,3 mm compr., glabro, lacínias $0,4-0,6 \mathrm{~mm}$ compr., glanduloso-pontoadas externamente. Anteras com base sagitada, apêndice apical lanceolado, ápice obtuso ou arredondado. Ramos do estilete lineares, mamilosos. Cipselas prismáticas, $3,6-4,3 \mathrm{~mm}$ compr., 0,6-0,8 mm diâm., glabras; carpopódio assimétrico, anelar. Pápus 4,4-5,1 mm compr.

Material examinado: Minas Gerais, Santana do Riacho, entre MG 010 e usina, 5.V.1991, bot. e fl., J.R. Stehmann et al. s.n. (BHCB 213777).

Material adicional examinado: Minas Gerais, Uberlândia, Reserva do Clube de Caça e Pesca Itororó de Uberlândia (CCPIU), 15.III.1996, fl., E.O. Leenza 407 (HUFU); CCPIU, 23.III.1996, fl., E.O. Leenza 411 (HUFU).

Chromolaena chaseae ocorre em Goiás, Mato Grosso, Mato Grosso do Sul, Minas Gerais, Rondônia, São Paulo, Tocantins e Distrito Federal, em áreas de Cerrado. $\mathrm{Na}$ área de estudo pode ser encontrada em borda de mata. Nakajima (2001) e Quaresma (2014) aproximam esta espécie de $C$. squalida, que se distingue por apresentar ramos hirsutos, capitulescência em panículas corimbiformes e receptáculo plano vs. ramos seríceo-tomentosos, capitulescência em dicásios e receptáculo convexo.

5.7 Chromolaena decumbens Gardner, London J. Bot. 5: 466.1846.

Ervas decumbentes, ca. $0,3 \mathrm{~m}$ alt. Ramo cilíndrico, multicostado, esparsamente hirsuto. Folhas opostas; sésseis, lâminas $0,1-0,4 \mathrm{~cm}$ compr., 0,1-1,6 $\mathrm{cm}$ larg., elípticas, ápice arredondado, raramente obtuso, base decorrente, margem crenada, ambas as faces glanduloso-pontoadas, face abaxial esparsamente hirsuta nas nervuras; paralelódromas.
Capítulo solitário, terminal, pedúnculo 1,8-138,9 mm compr., esparsamente hirsuto; invólucro cilíndricocampanulado, 5,3-9,3 mm compr., 2-7,3 mm larg., 46-seriado; brácteas involucrais com margem inteira, as externas 2,3-3,1 $\mathrm{mm}$ compr., 1,6-2,3 $\mathrm{mm}$ larg., ovadas, ápice curto mucronado, as medianas 4,4-4,6 $\mathrm{mm}$ compr., 2,3-2,4 $\mathrm{mm}$ larg., oblongas, ápice truncado, as internas $8,8-8,9 \mathrm{~mm}$ compr., $0,9-1,3 \mathrm{~mm}$ larg., oblongas, ápice agudo, arroxeado. Receptáculo convexo, curtamente piloso. Capítulo com até 67 flores; corola com tubo 4,1-5,9 mm compr., glabro, lacínias $0,7-1 \mathrm{~mm}$ compr., mamilosas internamente. Anteras com base sagitada, apêndice apical lanceolado. Ramos do estilete lineares, mamilosos. Cipselas prismáticas, 2,2-2,7 mm compr., 0,6-0,8 mm diâm., glabras, costas ciliadas; carpopódio assimétrico, anelar. Pápus 5,3-5,8 mm compr., cerdas com ápice lilás.

Material examinado: Minas Gerais, Congonhas do Norte, Serra Talhada, estrada para Extrema, ca. $11 \mathrm{Km}$ estrada para Lapinha, 20.I.2007, bot. e fl., J.R. Pirani et al. 5628 (HUFU, SPF); Santana do Pirapama, Fazenda Inhame (Serra Mineira), $18^{\circ} 55^{\prime}$ 'S 435' W, 22.III.1982, bot. e fl., J.R. Pirani et al. CFSC 8106 (SPF); RPPN Brumas do Espinhaço, estrada para a sede, aproximadamente $400 \mathrm{~m}$ da porteira da sede, $19^{\circ} 03^{\prime} 53^{\prime \prime S} 43^{\circ} 42^{\prime} 25 " W, 3$.VII.2015, fl. e fr., F.L. Contro et al. 157 (HUFU); Santana do Riacho, rodovia Belo Horizonte - Conceição do Mato Dentro, km 129, próximo à estatua do Velho Juca, 19॰15'44"S 4333'06"W, 2.II.2009, bot. e fl., J.R. Pirani et al. 5703 (MBM, SPF); Conceição do Mato Dentro, Capão Redondo, Fazenda Boa Esperança, margem esquerda da rodovia MG 010, km 145, 13.II.1996, bot. e fl., N. Roque et al. 147 (HUFU, SPF).

Chromolaena decumbens ocorre em Minas Gerais e São Paulo. Na área de estudo pode ser encontrada em áreas de campo rupestre, brejo e mata ciliar. A espécie é facilmente distinta por apresentar hábito decumbente com lâminas elípticas e margem crenada, receptáculo convexo e piloso e capítulos grandes (67 flores). A espécie é proximamente relacionada a $C$. ascendens e suas semelhanças foram discutidas anteriormente.

5.8 Chromolaena horminoides DC., Prodr. 5: 133. 1836.

Fig. 1L-N

Subarbustos, 0,5 m alt. Ramo cilíndrico, tomentoso-hirsuto, glanduloso-pontoado. Folhas opostas; pecíolo 1,9-3,4 $\mathrm{mm}$ compr., densamente tomentoso-hirsuto; lâminas 0,5-5,2 cm compr., 0,2$1,9 \mathrm{~cm}$ larg., lanceoladas, ápice curtamente mucronado, base atenuada, margem serreada, em ambas faces densamente tomentoso-hirsutas, glanduloso-pontoadas, peninérveas, craspedódromas. Capitulescência em panícula de dicásio, terminal, capítulos pedunculados; pedúnculo 1,6-24,5 mm compr., tomentoso-hirsuto; invólucro ovoide-cilíndrico, 6,5-13,5 mm compr., 5,6-8,7 mm larg., 6-8-seriado; brácteas involucrais com ápice agudo, lilás, as 


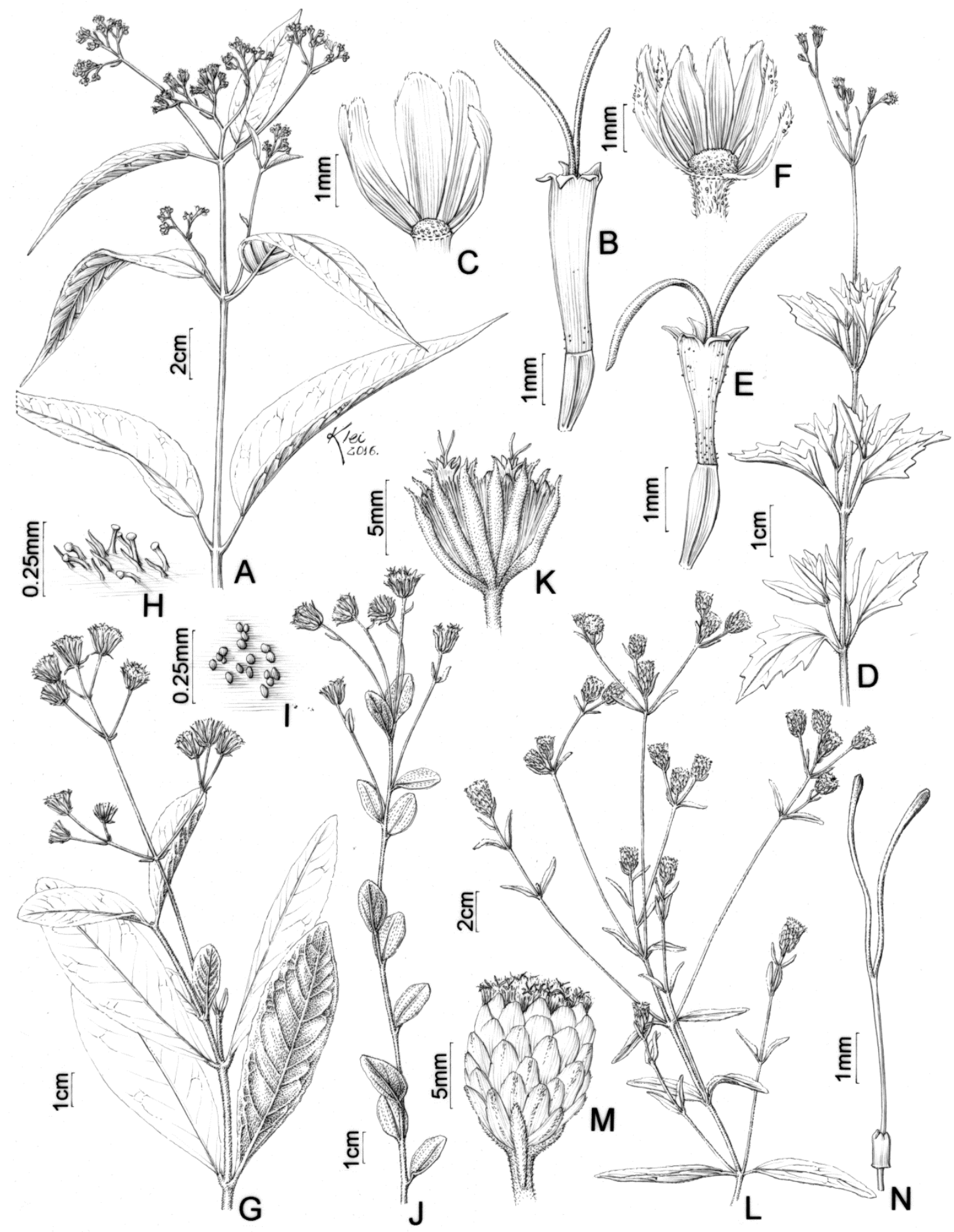

Fig. 1: A-C. Acritopappus longifolius (Gardner) R.M.King \& H.Rob. A. Ramo. B. Capítulo. C. Flor. D-F. Ageratum myriadenium (Sch.Bip. ex Baker) R.M.King \& H.Rob. D. Ramo. E. Capítulo. F. Flor. G-I. Ayapana amygdalina (Lam.) R.M.King \& H.Rob. G. Ramo. H-I. Detalhe dos tricomas glandulares e multicelulares. J-K. Campuloclinium riedelli (Baker) R.M.King \& H.Rob. J. Ramo. K. Capítulo. L-N. Chromolaena horminoides DC. L. Ramo. M. Capítulo. N. Detalhe dos ramos do estilete. (A. I.M.Franco 1221; D. I.R.Andrade 325; G. R.Romero 3584; J. F.L.Contro 22; L. F.L.Contro 56). 
externas 2,6-4,8 $\mathrm{mm}$ compr., 1,3-1,7 $\mathrm{mm}$ larg., lanceoladas, as medianas 6,7-8,5 mm compr., 2,6-2,8 $\mathrm{mm}$ larg., lanceoladas ou ovado-lanceoladas, as internas 105-115 mm compr., 16-19 mm larg., estreito-oblonga, ápice curtamente serrilhado. Receptáculo plano, epaleáceo. Capítulo com ca 24 flores; corola com tubo 4,6 mm compr., lacínias 0,8 $\mathrm{mm}$ compr., papilosas externamente. Anteras com base sagitada, apêndice apical lanceolado, colar cilíndrico. Ramos do estilete lineares, ápice obtuso, papilosos. Cipsela obcônica, 2,8-3,6 mm compr., 0,50,9 mm diâm., glabra, costas ciliadas; carpopódio simétrico, anelar. Pápus cerdoso, 4,5 mm compr.

Material examinado: Minas Gerais, Santana do Riacho, Serra da Lapinha, a $50 \mathrm{~km}$ da rodovia Belo Horizonte-Conceição do Mato Dentro, 27.III.1991, fl., J.R. Pirani et al. 12212 (HUFU, SPF); Serra do Cipó, Estrada de São José de Almeida para Cardeal Mota, segunda entrada para MG 020, 19²2'49"S 4340'13"W, 29.VI.2015, bot. e fl., F.L. Contro et al. 56 (HUFU); PARNA Serra do Cipó, sertão entre Lagoa Santa e Serra do Cipó, 14.IV.1950, bot. e fl., A.P. Duarte 2437 (HUFU, RB); Santana do Pirapama, 17.III.1971, bot. e fl., L. Krieger 10116 (HUFU, UFJF); PARNA Serra do Cipó, Congonhas, próximo à casa de pedra, 20.V.1989, bot. e fl., M.G.L. Wanderley et al. CFSC 11483 (HUFU, SPF); Santana do Riacho, acesso pela Fazenda Inhame, perto do estabulo, morro do Godfrey, Capela de São José, 1900'20"S 4346'30"W, 16.III.2009, bot.e fl., D.C. Zappi et al. 2176 (RB, SPF); Santana do Pirapama, 17.III.1971, bot. e fl., L. Krieger 10116 (MBM)

Chromolaena horminoides encontra-se distribuída na Bahia, Espírito Santo, Goiás, Mato Grosso, Mato Grosso do Sul, Minas Gerais, São Paulo, Distrito Federal e nos domínios da Caatinga, Cerrado e Mata Atlântica. Na área de estudo pode ser encontrada em áreas de cerrado rupestre e cerrado denso. A espécie é distinta das demais na área por apresentar o invólucro quase todo lilás.

5.9 Chromolaena ivifolia (L.) R.M.King \& H.Rob., Phytologia 20(3): 202. 1970.

Subarbustos, 0,4 m alt. Ramo cilíndrico, multicostado, tomentoso. Folhas alternas; sésseis, lâminas 0,8-2,3 mm compr., 0,1-0,6 mm larg., lanceoladas, ápice agudo, base decurrente, margem denteada, inteira no terço inferior, face adaxial esparso-tomentosa, glanduloso-pontoada, face abaxial glanduloso-pontoada, serícea nas nervuras, paralelódromas. Capitulescência em panículas corimbiformes, capítulos com pedúnculo 0,8-10,5 mm compr., tomentoso, glanduloso-pontoado; invólucro cilíndrico, 2,6-8,5 mm compr., 1,7-2,7 mm larg., 4-6seriado; brácteas involucrais com ápice truncadocuspidado, magenta (ou rosa escuro), margem ciliada no terço superior, porção mediana superior glanduloso-pontoada, as externas 1,6-2,4 mm compr., 1,1-1,2 mm larg., obovadas, as medianas 3,2-3,5 mm compr., 1,1-1,3 mm larg., obovadas, as internas 4,7-5 $\mathrm{mm}$ compr., 1-1,3 mm larg., linear-lanceoladas. Receptáculo plano, glabro. Capítulo com 12 flores; corola lilás, tubo 3,3 $\mathrm{mm}$ compr., esparsamente glanduloso-pontoado; lacínias 0,6 mm compr., mamilosas internamente, arroxeadas, glandulosopontoadas externamente. Anteras com base curtamente sagitada, apêndice apical lanceolado. Ramos do estilete lineares, arroxeados, papilosos, espessados no ápice. Cipsela prismática, 1,7-2,2 mm compr., 0,3-0,6 mm diâm., costas ciliadas; carpopódio assimétrico, anelar. Pápus filiforme, 3,4-3,9mm.

Material examinado: Minas Gerais, Santana do Pirapama, trilha da Senhorinha, primeiro platô, 1855'22"S e 4344'37"W, 9.III.2009, bot. e fl., D.C. Zappi 1961 (RB); Serra do Cipó, estrada para Conceição do Mato Dentro, cerca de $10 \mathrm{Km}$ de Cardeal Mota, aproximadamente $\mathrm{km} \mathrm{106,}$

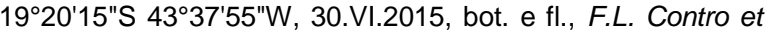
al. 77 (HUFU).

Chromolaena ivifolia ocorre na Bahia, Espirito Santo, Goiás, Mato Grosso, Mato Grosso do Sul, Minas Gerais, Paraná, Rio de Janeiro, Rio Grande do Sul, Santa Catrina, São Paulo e Distrito Federal, nos domínios do Cerrado e Mata Atlântica. $\mathrm{Na}$ área de estudo distribui-se em cerrado rupestre e campo rupestre. A espécie pode ser reconhecida por apresentar capítulos pequenos (até $8 \mathrm{~mm}$ compr.), folhas pequenas e estreitas e pápus filiforme ou capilar.

5.10 Chromolaena laevigata (Lam.) R.M.King \& H.Rob., Phytologia 20 (3): 202. 1970.

Arbustos, 1-1,8 m alt. Ramo cilíndrico, multicostado, glanduloso-pontoado. Folhas opostas; subsésseis ou com pecíolo 3,2-4,8 $\mathrm{mm}$ compr., glabrescente, esparso-hirsuto; lâminas 1,1-8,2 cm compr., 0,4-2,8 cm larg., lanceoladas, ápice agudo, base decorrente ou aguda, margem serreada na metade superior, face adaxial glabra, face abaxial glanduloso-pontoada, hirsuta nas nervuras, paralelódromas. Capitulescência em panículas; capítulos com pedúnculo 1,7-7,6 mm compr., glabro; invólucro cilíndrico, 2,4-10,3 mm compr., 1,6-4,4 mm larg., 3-5(-6) seriado; brácteas involucrais com margem inteira, as externas 1,1-1,8 mm compr., 1,6$1,7 \mathrm{~mm}$ larg., ovadas a triangulares, ápice agudo, ciliado, margem ciliada na metade superior, as medianas 2,9-5,1 mm compr., 1,5-2 mm larg., oblongas, ápice obtuso, ciliado, margem ciliada no terço superior, as internas 7,5-10,7 mm compr., 1,1$1,2 \mathrm{~mm}$ larg., lineares, ápice agudo ou às vezes acuminado, ciliado. Receptáculo convexo a cônico, glabro. Capítulo com 23 flores; corola com tubo 4,74,9 mm compr., glabro; limbo indiferenciado; lacínias 0,8-0,9 mm compr., mamilosas internamente. Anteras com base curto-sagitada, apêndice apical lanceolado, ápice arredondado. Ramos do estilete lineares, mamilosos. Cipsela obcônica, 3,65-4 mm compr., 0,6$0,8 \mathrm{~mm}$ diâm., glabra; carpopódio assimétrico, anelar. Pápus cerdoso, 3,8-4,2 mm compr.

Material examinado: Minas Gerais, Serra do Cipó, estrada para Conceição do Mato Dentro, aproximadamente 
Km 123, 19¹3'26"S 4330'07"W, 30.VI.2015, fl., F.L. Contro et al. 85 (HUFU); Estrada para Conceição do Mato Dentro,

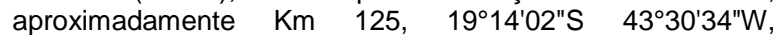
30.VI.2015, bot. e fl., F.L. Contro et al. 89 (HUFU); Estrada para Morro do Pilar, aproximadamente $\mathrm{Km}$ 205, 1.VII.2015, bot., fl. e fr., F.L. Contro et al. 133 (HUFU); Santana do Riacho, rodovia Belo Horizonte - Conceição do Mato Dentro, mata do Córrego Três Pontinhas, 25.IV.1992, bot. e fl., J.R. Pirani et al. CFSC 12942 (HUFU, SPF).

Chromolaena laevigata pode ser encontrada no Acre, Amazonas, Bahia, Espírito Santo, Goiás, Mato Grosso, Mato Grosso do Sul, Minas Gerais, Paraná, Rio de Janeiro, Rio Grande do Sul, Santa Catarina, São Paulo e Distrito Federal, nos domínios da Amazônia, Caatinga, Cerrado e Mata Atlântica. Na área de estudo ocorre em cerrado s.s. A espécie é bastante parecida com Symphyopappus reticulatus Baker por ambas apresentarem folhas grandes e largas, lanceoladas, paralelódromas e com maregem serreada e, às vezes, vernicosas.

Para distinção das espécies é necessária a observação do pápus, que permite fácil reconhecimento, uma vez que em $C$. laevigata é unisseriado e livre na base e, em $S$. reticulatus é bisseriado e unido na base.

\subsection{Chromolaena multiflosculosa}

(DC.)

$$
\text { R.M.King \& H.Rob., Phytologia 20: 203. } 1970 .
$$

Arbustos, até $0,7 \mathrm{~m}$ alt. Ramo cilíndrico, multicostado, hirsuto. Folhas opostas; com pecíolo 1,2-4,1 mm compr., densamente hirsuto; lâminas 0,3$1,6 \mathrm{~cm}$ compr., $0,1-0,6 \mathrm{~cm}$ larg., lanceoladas, ápice mucronado, base aguda, margem inteira ou às vezes serreada, face adaxial escabra, face abaxial densamente hirsuta, glanduloso-pontoada, camptódromas. Capitulescência em panículas de dicásio; capítulos com pedúnculos 1-7,5 mm compr., hirsutos; invólucro estreito-campanulado 2,5-9,2 mm compr., 1,8-5,7 mm larg., 3-5-seriado; brácteas involucrais com margem inteira, as externas 1,6-2 mm compr, 0,8-1,3 mm larg., triangulares a ovadas, ápice arredondado, margem ciliada, as medianas 1,9-5,2 $\mathrm{mm}$ compr., 0,8-1,4 $\mathrm{mm}$ larg., oblongas, ápice arredondado, ciliado, as internas 3,1-8,2 mm compr., 0,4-0,6 mm larg., linear, ápice agudo, ciliado. Receptáculo levemente convexo, glabro. Capítulo com até 45 flores; corola com tubo 0,9-1,4 mm compr., glabro; limbo 2,9-3,4 mm compr., glabro; lacínias 0,6$0,7 \mathrm{~mm}$ compr., esparsamente glanduloso-pontoadas externamente, mamilosas internamente. Anteras com base arredondada, apêndice apical agudo. Ramos do estilete lineares, mamilosos. Cipselas obcônicas, 2,43,2 mm compr., 0,3-0,7 mm diâm., costas ciliadas; carpopódio simetrico, anelar. Pápus cerdoso, 4,2-4,7 $\mathrm{mm}$ compr.

Material examinado: Minas Gerais, Santana do Riacho, MG 010, $23 \mathrm{~km}$ da ponte do Rio Cipó, próximo à estatua do Juquinha, $19^{\circ} 15^{\prime} 48^{\prime \prime} \mathrm{S} 43^{\circ} 33^{\prime} 31^{\prime \prime W}, 23$.V.2009, bot. e fl., L. Menini Neto et al. 688 (HUFU, RB, SPF); RPPN Brumas do Espinhaço e Ermo dos Gerais, 11.IV.2014, Carvalho et. al. s.n. (BHCB 186564).

\section{Chromolaena multiflosculosa ocorre nos} estados de Goiás, Mato Grosso e Minas Gerais. Na área de estudo pode ser encontrada em campo rupestre. Almeida (2008) caracteriza a espécie pelas lâminas foliares com face abaxial glanduloso-pontoada e as inferiores caducas, capítulos grandes e cipselas glabras.

Tanto Almeida (2008) como Quaresma (2014) aproximam esta espécie de $C$. barbacensis, contudo esta possui todas suas folhas persistentes e capítulos menores (até 29 flores), brácteas com ápice agudo e receptáculo plano (vs. capítulos grandes com 45 flores, brácteas com ápice arredondado e receptáculo convexo).

5.12 Chromolaena oxylepis (DC.) R.M.King \& H.Rob., Phytologia 20: 204. 1970.

Subarbustos a arbustos, 1-1,5 m alt. Ramo cilíndrico, patente, multicostado, esparso-estrigoso, hirsuto, glanduloso-pontoado. Folhas opostas, às vezes patentes; sésseis ou com pecíolo 1,6-6,8 mm compr., hirsuto; lâminas 0,5-4,5 cm compr., 0,2-1,4 $\mathrm{cm}$ larg., lanceoladas, ápice agudo a curto-mucronado, base cuneada e decorrente, margem denteada na metade superior, face adaxial estrigosa, glandulosopontoada, face abaxial velutinea, glandulosopontoada, paralelódromas. Capitulescência em panículas patentes; capítulos com pedúnculo 1,1-4,9 $\mathrm{mm}$ compr., estrigoso, glanduloso-pontoado; invólucro cilíndrico, 4-12,3 mm compr., 1,6-4,4 mm larg., 4-7seriado; brácteas involucrais com ápice agudo, curtociliado, margem inteira, as externas 1,1-1,8 mm compr., 0,8-1,1 $\mathrm{mm}$ larg., triangulares, as medianas 5,7-6,4 mm compr., 1-1,8 mm larg., lanceoladas, as internas 9,2-12 mm compr., 0,7-0,8 mm larg., linear a linear-lanceoladas. Receptáculo convexo, glabro. Capítulo 15-24 flores; corola com tubo 3,5-3,6 mm compr., esparsamente coberto por tricomas glandulares; limbo não diferenciado; lacínias 0,5-0,6 $\mathrm{mm}$ compr., externamente coberta por tricomas glandulares, mamilosas internamente. Anteras com base arredondada a levemente cordada, apêndice apical lanceolado, ápice arredondado. Ramos do estilete lineares a subclaviformes. Cipselas obcônicas, levemente cilíndricas, 3,2-3,6 mm compr., 0,5-0,8 mm diâm., glabras; carpopódio simétrico, anelar. Pápus cerdoso, 3,6-4 mm compr.

Material examinado: Minas Gerais, Fazenda Inhame (Serra Mineira), $18^{\circ} 55^{\prime} \mathrm{S} 43^{\circ} 54^{\prime} \mathrm{W}, 20.1 \mathrm{II} .1982$, bot. e fl., J.R. Pirani et al. CFSC 7965 (SPF); Serra do Cipó, estrada para Conceição do Mato Dentro, cerca de $10 \mathrm{~km}$ de Cardeal

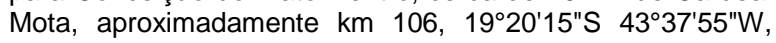
30.VI.2015, bot. e fl., F.L. Contro et al. 81 (HUFU); Serra do Cipó, estrada para Conceição do Mato Dentro, cerca de 10 $\mathrm{km}$ de Cardeal Mota, aproximadamente km 106, 19०20'15"S 4337'55"W, 30.VI.2015, bot. e fl., F.L. Contro et al. 82 
(HUFU); Estrada para Conceição do Mato Dentro, entrada para Serra Morena, aproximadamente $1 \mathrm{~km}$ do Chapéu de Sol, 30.VI.2015, fl., F.L. Contro et al. 75 (HUFU); Estrada para Conceição do Mato Dentro, entrada para Serra Morena, aproximadamente $1 \mathrm{~km}$ do Chapéu de Sol, 30.VI.2015, fl., F.L. Contro et al. 74 (HUFU); Estrada de São José de Almeida para Cardeal Mota, segunda entrada para MG 020, aproximadamente $\mathrm{km} \quad 88,1^{\circ} 22^{\prime} 49^{\prime \prime S} \quad 43^{\circ} 40^{\prime} 13^{\prime \prime} \mathrm{W}$, 29.VI.2015, bot. e fl., F.L. Contro et al. 61 (HUFU); Estrada de Lapinha da Serra para RPPN Brumas do Espinhaço, 1903'59"S 4342'24"W, 2.VII.2015, bot., fl. e fr., F.L. Contro et al. 139 (HUFU); Entrada da RPPN Brumas do Espinhaço, 19॰04'11"S 4342'24"W, 2.VII.2015, fl. e fr., F.L. Contro et al. 145 (HUFU).

Chromolaena oxylepis distribui-se nos estados de Goiás, Minas Gerais, Paraná e São Paulo, ocorrendo nos domínios de Cerrado e Mata Atlântica. $\mathrm{Na}$ área de estudo pode ser encontrada em áreas de Cerrado s.s., campo rupestre e borda de estrada. As variedades da espécie não foram consideradas neste trabalho.

A espécie é facilmente reconhecida por apresentar todas as brácteas involucrais com ápice agudo e muito similar à Chromolaena pungens, porém esta apresenta suas brácteas internas com ápice mucronado.

5.13 Chromolaena pedalis (Sch.Bip. ex Baker) R.M.King \& H.Rob., Phytologia 20: 204. 1970.

Arbusto, 0,5 m alt. Ramo cilíndrico, multicostado, esparsamente seríceo, glandulosopontoado próximo ao ápice. Folhas alternas; pecíolo 0,7-2,9 mm, seríceo, glanduloso-pontoado; lâminas 0,5-2,6 cm compr., 0,1-1,4 cm larg., ovadas a lanceoladas, ápice obtuso ou raramente arredondado, base aguda, margem serreada, face adaxial esparsamente serícea, glanduloso-pontoada, face abaxial serícea nas nervuras, glanduloso-pontoada, paralelódromas. Capitulescência em panículas corimbiformes; capítulos com pedúnculo 0,8-4,9 mm, seríceo, glanduloso-pontoado; invólucro cilíndrico, 5,786,5 mm compr., 2,4-3,4 mm larg., 5-(-6)-seriado; brácteas involucrais com ápice reflexo, face adaxial glanduloso-pontoada, as externas 1,8-1,9 mm compr., 0,9-1,1 mm larg., ovadas, ápice agudo, margem ciliada, as medianas 2,7-3 $\mathrm{mm}$ compr., 1-1,1 mm larg., oblongas, ápice truncado, margem ciliada no terço superior, as internas 5,3-5,8 mm compr., 0,7-1 mm larg., estreito-oblongas, ápice truncado, margem ciliada no terço superior. Receptáculo plano, glabro. Capítulo com 11 flores; corola com tubo 3,8-4,1 mm compr., glanduloso-pontoado; lacínias mamilosas. Anteras com base arredondada, apêndice apical triangular. Ramos do estilete lineares, papilosos. Cipselas obcônicas, 0,91,8 mm compr., 0,2-0,5 mm diâm., seríceas próximo ao carpopódio; carpopódio assimétrico, anelar. Pápus 3,34,1 mm compr., cerdas com ápice espessado.

Material examinado: Minas Gerais, Parque Nacional da Serra do Cipó, 18.II.1972, fl. e fr., W.R. Anderson et al. 36178 (HUFU, RB).
Material adicional examinado: Minas Gerais, Serra do Caraça, 21.III.1957, fl., E. Pereira 3355 (HUFU); Diamantina, Parque Estadual do Biribiri, Alto da Jacuba, 14.III.2012, fl., D. Marques 433 (HUFU).

Chromolaena pedalis ocorre em Goiás, Minas Gerais, Rio de Janeiro e São Paulo, em Cerrado e Mata Atlântica. Almeida (2008) caracteriza a espécie e a diferencia das demais pela presença de brácteas involucrais com ápice reflexo e densamente glanduloso-pontoadas.

5.14 Chromolaena pedunculosa (Hook. \& Arn.) R.M.King \& H.Rob., Phytologia 47: 231. 1980.

Arbustos, até $1,5 \mathrm{~m}$ alt. Ramo cilíndrico, multicostado, seríceo. Folhas opostas; pecíolo 0,9-4 $\mathrm{mm}$ compr., seríceo; lâminas 1,2-2,1 cm compr., 0,1$1,3 \mathrm{~cm}$ larg., ovadas, ápice mucronado, base aguda, margem serreada, face adaxial híspida, face abaxial densamente serícea, paralelódromas. Capitulescência em dicásio; capítulos com pedúnculo 1,1-10 mm, seríceo; invólucro estreito-campanulado, 2,5-12,1 mm compr., 2-5,8 mm larg., 3-6-seriado; brácteas involucrais com ápice agudo, ciliado, margem inteira, glabras, as externas 2,2-2,7 mm compr., 1,4-1,7 mm larg., triangulares, as medianas 6,2-7,7 mm compr., 1,9-2,2 mm larg., ovadas, ápice agudo, as internas 10,3-10,4 mm compr., 1-1,2 mm larg., lineares. Receptáculo convexo, glabro. Capítulo com ca. 25 flores; corola com tubo 4,7-5,3 mm compr., esparsamente glanduloso-pontoado; lacínias 0,8-0,9 $\mathrm{mm}$ compr., glanduloso-pontoada externamente, papilosas internamente. Anteras com base sagitada, apêndice apical lanceolado. Ramos do estilete lineares, papilosos. Cipselas obcônicas, 3-3,4 mm compr., 0,5-1 mm diâm., glabras; carpopódio assimétrico, anelar. Pápus cerdoso, 4,9-5,2 mm compr.

Material examinado: Minas Gerais, Santana do Riacho, usina, 5.V.1991, bot. e fl., J.R. Stehmann et al. s.n. (BHCB 19210).

Material adicional examinado: Minas Gerais, Uberlândia, CCPIU, borda da vereda 1, lado direito, 7.IV.2000, fl., G.M. Araújo 3160 (HUFU); CCPIU, 28.III.2003, fl., A.A.A. Barbosa s.n. (HUFU 31750).

Chromolaena pedunculosa ocorre no Paraná, Rio Grande do Sul, Santa Catarina e São Paulo, nos domínios do Cerrado, Mata Atlântica e Pampa. Até o presente não existem dados publicados sobre a ocorrência desta espécie no estado de Minas Gerais, sendo assim, este trabalho traz a ampliação da distribuição geográfica desta espécie.

Chromolaena pedunculosa pode ser reconhecida por apresentar capitulescência em dicásio, folhas profundamente denteadas e híspidas na face adaxial e lacínias da corola papilosas internamente. 
5.15 Chromolaena pungens (Gardner) R.M.King, \& H.Rob., Phytologia 47: 231. 1980.

Arbustos, até $1 \mathrm{~m}$ alt. Ramo cilíndrico, multicostado, escabro, esparso glanduloso-pontoado. Folhas opostas; pecíolo 1,6-4,9 mm compr., escabro, glanduloso-pontoado; lâminas 0,6-3,4 mm compr., 0,1-1 cm larg., lanceoladas, ápice agudo ou curtamente mucronado, base aguda, margem denteada na metade superior, face adaxial escabra, face abaxial escabra, glanduloso-pontoada, camptódromas. Capitulescência em panículas de panículas; capítulos com pedúnculo 1,4-12,5 mm compr., escabro, glanduloso-pontoado; invólucro cilíndrico, 3,5-10,5mm compr., 1,6-4,5 mm larg., 4-6seriado; brácteas involucrais com ápice agudo, as externas 1,5-2,3 mm compr., 0,9-1,3 mm larg., triangulares, margem ciliada no terço superior, estrias longitudinais marrons na face adaxial, as medianas 45,5 mm compr., 1,3-1,5 mm larg., lanceoladas, ápice curtamente ciliado, as internas $8,3-8,7 \mathrm{~mm}$ compr., 0,8-1 mm larg., lineares, ápice agudo ou curtamente mucronado. Receptáculo plano, glabro. Capítulo com 18 flores; corola com tubo 3-3,5 mm compr., glabro, glanduloso-pontoado; lacínias $0,7 \mathrm{~mm}$ compr., papilosos internamente, glanduloso-pontoado externamente. Anteras com base curtamente sagitada, apêndice apical lanceolado. Ramos do estilete com ápice obtuso, papilosos. Cipselas obcônicas, 2,2-3,8 $\mathrm{mm}$ compr., $0,5 \mathrm{~mm}$ diâm., glabras; carpopódio simétrico, anelar. Pápus cerdoso, 3,5-3,6 mm compr.

Material examinado: Minas Gerais, Santana do Pirapama, distrito de São José da Cachoeira, Fazenda Toucán Cipó, estrada para a captação, 190'18"S 4346'6"W, 15.Il.2007, bot. e fl., D.C. Zappi et al. 706 (ESA, RB); Santana do Pirapama, Serra do Cipó (Serra da Lapa), Distrito de São José da Cachoeira, Fazenda Toucán Cipó próximo ao alojamento, $19^{\circ} 00^{\prime} 22 " S 43^{\circ} 45^{\prime} 20^{\prime \prime W}$, 18.II.2007, bot. e fl., V.C. Souza et al. 32716 (ESA, HUFU, RB); Santana do Pirapama, acesso pela Faz. Inhame, estrada ligando a Capela de São José a Santana do Riacho, 1859'44"S 4345'50"W, 5.III.2009, bot. e fl., D.C. Zappi et al. 1695 (RB, SPF).

Chromolaena pungens ocorre na Bahia, Goiás, Maranhão, Mato Grosso, Mato Grosso do Sul, Minas Gerais, Pará, Paraná, São Paulo e Distrito Federal. Na área de estudo pode ser encontrada em cerrado. A espécie apresenta evidentes estrias longitudinais marrons na face adaxial das brácteas involucrais, margem denteada a partir da metade e ambas faces das lâminas foliares escabras.

\subsection{Chromolaena sagittifera (B.L.Rob.)} R.M.King \& H.Rob., Phytologia 20: 206.1970.

Ervas, 0,2-0,4 $\mathrm{m}$ alt. Ramo cilíndrico, multicostado, tomentoso. Folhas alternas; sésseis; lâminas $0,4-1,5 \mathrm{~mm}$ compr., $0,1-0,5 \mathrm{~mm}$ larg., sagitadas, ápice agudo, base sagitada, margem inteira, revoluta, ambas as faces esparsamente glanduloso-pontoada, acródromas. Capitulescência em racemos; capítulos com longo pedúnculo 17-46,6 $\mathrm{mm}$ compr., tomentoso; invólucro cilíndricocampanulado 6,1-10,8 mm compr., 4,6-7,4 mm larg., 4-6-seriado; brácteas involucrais com ápice cuspidado, margem inteira, as externas $3,5-3,9 \mathrm{~mm}$ compr., 1,8-2 mm larg., oblongas, margem ciliada, face dorsal esparsamente pilosa, as medianas 5,5-6,4 $\mathrm{mm}$ compr., 1,7-1,9 mm larg., oblongo-lanceoladas, margem esparsamente pilosa no terço superior, glanduloso-pontoadas, as internas 6,5-6,7 $\mathrm{mm}$ compr., 1,4-1,6 mm larg., oblanceoladas a oblongas, margem esparsamente pilosa no terço superior, galnduloso-pontoada. Receptáculo convexo, páleas 6,5-6,8 mm compr., 0,7-0,9 mm larg., lineares, ápice agudo, hirsuto no terço superior na face adaxial. Capítulo com 61 flores; corola com tubo 2,1-4,5 mm compr., glabro; lacínias $0,6 \mathrm{~mm}$ compr., papilosas externamente. Anteras com base curtamente sagitada, apêndice apical ovado. Ramos do estilete lineares, papilosos. Cipselas prismáticas, 2,2-3,3 $\mathrm{mm}$ compr., 0,3-0,8 mm diâm., glabras, costas esparsamente ciliadas; carpopódio assimétrico, anelar. Pápus 4-5,5 $\mathrm{mm}$ compr., cerdas espessadas no ápice.

Material examinado: Minas Gerais, Santana do Pirapama, trilha da Senhorinha, primeiro platô, 1858'20"S e 43ํ5'17"W, 8.III.2009, fl., D.C. Zappi 1905 (RB); 16.III.1964, bot. e fl., E. Pereira 8911 (RB); Jaboticatubas, Alto da Serra da Lagoa Dourada, 12.II.1996, bot. e fl., N. Roque et al. 113 (HUFU, SPF); RPPN Brumas do Espinhaço, estrada para a sede, aproximadamente $400 \mathrm{~m}$ da porteira da sede, $19^{\circ} 03^{\prime} 53^{\prime \prime S}$ 4342'25"W, 3.VII.2015, fl., F.L. Contro et al. 158 (HUFU); Jaboticatubas, Alto da Serra da Lagoa Dourada, 12.II.1996, bot. e fl., N. Roque et al. 113 (HUFU, R, SPF); Santana do Riacho, PARNA Serra do Cipó, região do Congonhas, abaixo da Casa de Pedra, próximo ao córrego do Gavião, 21.III.1992, bot. e fl., M. Pereira \& M. Lucca 845 (BHCB).

Chromolaena sagittifera é endêmica de Minas Gerais. Na área de estudo ocorre em campo limpo, campo rupestre e campos arenosos com afloramentos rochosos. A espécie é facilmente reconhecível por apresentar suas folhas sagitadas ou ovais com base sagitada. O capítulo desta espécie é similar ao de $C$. horminoides, no entanto esta apresenta quase todo seu invólucro arroxeado, enquanto $C$. sagittifera apresenta brácteas com ápice levemente acastanhado.

\subsection{Chromolaena squalida (DC.) R.M.King \&} H.Rob., Phytologia 20: 206. 1970

Arbustos, até $1,5 \mathrm{~m}$ alt. Ramo cilíndrico, hirsuto, glanduloso-pontoado. Folhas opostas; pecíolo 1,9-3,4 mm compr., hirsuto; lâminas $0,3-1 \mathrm{~cm}$ compr., $0,2-0,6 \mathrm{~cm}$ larg., ovadas ou elípticas, ápice agudo ou levemente mucronado, base aguda ou atenuada, margem inteira, face adaxial estrigosa, esparso glanduloso-pontoada, face abaxial tomentosa, glanduloso-pontoada, acródromas. Capitulescência em panículas corimbiformes; capítulos com pedúnculo 1,1-5,4 mm compr., hirsuto; invólucro cilíndrico, 5,3- 
10,4 mm compr., 2,4-4,4 mm larg., 4-7-seriado; brácteas involucrais com ápice agudo, margem inteira, as externas 2,1-3,2 mm compr., 1,4-1,7 mm larg., ovais, ápice ciliado, as medianas 5,1-5,6 mm compr., 1,7-1,8 mm larg., lanceoladas, ápice pouco ciliado, as internas 9,2-10 mm compr., 0,7-1 mm larg., oblongolanceolada, glabras. Receptáculo plano, glabro. Capítulo com 29 flores; corola com tubo 5-6 mm compr., hirsuto; lacínias 0,5-0,7 mm compr., papilosas interna e externamente. Anteras com base arredondada, apêndice apical lanceolado. Ramos do estilete lineares, papilosos. Cipselas obcônicas, 3,7-4 $\mathrm{mm}$ compr., 0,7-0,8 mm diâm., costas ciliadas; carpopódio assimétrico, anelar. Pápus cerdoso, 4,6 $\mathrm{mm}$ compr.

Material examinado: Minas Gerais, perto do Hotel Palácio, bot., fl. e fr., 5.IV.1951, G.A. Black \& M. Magalhães 51-11931 (RB); Santana do Riacho, RPPN Brumas do Espinhaço e Ermo dos Gerais, 31.I.2013, bot., fl. e fr., J. Ordones et al. 2186 (BHZB, HUFU); Santana do Riacho, Serra do Cipó, rodovia Belo Horizonte-Conceição do Mato Dentro, km 126, Alto do Palácio, 26.Il.1991, bot. e fl., J.R. Pirani et al. CFSC 12100 (HUFU, SPF); Congonhas do Norte, Serra da Mangabeira, próximo a margem direita do Rio Preto, $18^{\circ} 50^{\prime} S 43^{\circ} 49^{\prime} \mathrm{W}, 23 . I V .1982$, bot. e fl., A. Furlan et al. CFSC 8423 (SPF); Congonhas do Norte, Serra da Mangabeira, próximo a margem direita do Rio Preto, $18^{\circ} 50^{\prime} \mathrm{S} 43^{\circ} 49^{\prime} \mathrm{W}$, 23.IV.1982, bot. e fl., A. Furlan et al. CFSC 8428 (SPF); Serra do Cipó, 3.IV.1958, bot. e fl., F. Atala 178 (R); Serra do Cipó, Hotel Veraneio, 7.IV.1957, bot. e fl., E. Pereira 2931 (RB); Congonhas do Norte, trilha em direção ao Retiro do Barbaro,

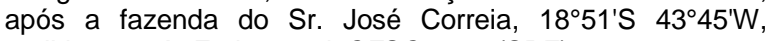
21.IV.1982, A. Furlan et al. CFSC 8356 (SPF).

Chromolaena squalida possui ampla distribuição no país, ocorrendo na Bahia, Espírito Santo, Goiás, Mato Grosso, Mato Grosso do Sul, Minas Gerais, Pará, Paraná, Rio de Janeiro, Rio Grande do Sul, Rondônia, Santa Catarina, São Paulo, Tocantins e Distrito Federal. $\mathrm{Na}$ área de estudo pode ser encontrada em brejos e campos rupestres. Neste trabalho não foram adotadas as variedades da espécie. Os espécimes estudados da Serra do Cipó apresentam uma grande variação morfológica, contudo todos possuem suas lâminas foliares ovadas a elípticas com face adaxial estrigosa e face abaxial tomentosa.

É uma espécie bastante comum e frequente, e pode ser reconhecida pelo indumento das folhas, que se caracteriza por ser estrigoso na face adaxial e tomentoso na abaxial.

5.18 Chromolaena stachyophylla (Spreng.) R.M.King \& H.Rob., Phytologia 20: 206. 1970.

Ervas a subarbustos, $1 \mathrm{~m}$ alt. Ramo cilíndrico, multicostado, hirsuto, glanduloso-pontoado. Folhas alternas, sésseis; lâminas 0,9-5,7 cm compr., 0,2-0,7 $\mathrm{cm}$ larg., lanceolada, ápice agudo, base decurrente, margem inteira ou serreada na metade superior, face adaxial glabrescente, face abaxial hirsuta a glabrescente, glanduloso-pontoada, acródromas.
Capitulescência em panículas corimbiformes, quase formando glomérulos; capítulos sésseis; invólucro cilíndrico, 3(-4)-seriado; brácteas involucrais 3,1-5,7 $\mathrm{mm}$ compr., 1,1-1,6 mm larg., lanceoladas ou ovadolanceoladas, ápice acuminado (internas) ou obtuso (externas), ciliado, margem inteira, terço superior com tricomas. Recptáculo plano, glabro. Capítulo com 6-7 flores; corola com tubo 3,5-4,4 mm, glabro; lacínias $0,9 \mathrm{~mm}$ compr., papilosas externamente. Anteras com base sagitada, apêndice apical lanceolado. Ramos do estilete lineares, papilosos. Cipselas prismáticas, 2,4$3 \mathrm{~mm}$ compr., 0,4-0,8 mm diâm., setosas; carpopódio assimétrico, anelar. Pápus cerdoso, 4,3-4,8 mm compr.

Material examinado: Minas Gerais, Jaboticatubas, estrada de Jaboticatubas - Almeida, fl., F.L. Contro 2 \& D. Marques (HUFU); Santana do Pirapama, trilha da Senhorinha, $19^{\circ} 00^{\prime} 22$ "S e $43^{\circ} 45^{\prime} 20^{\prime \prime} \mathrm{W}$, fl. e fr., 19.Il.2007, V.C. Souza et al. 32814 (RB); Jaboticatubas, $5-6 \mathrm{~km}$ ao norte do ribeirão Andrequicé, $19^{\circ} 14^{\prime}$ 'S e $43^{\circ} 32 ' 33 " \mathrm{~W}$, fl., 21.XI.1965, G. Eiten \& L.T. Eiten 6745 (RB); Serra do Cipó, rodovia para Conceição do Mato Dentro, aproximadamente $\mathrm{km} \mathrm{115,}$ 17.XII.2014, bot., fl. e fr., F.L. Contro 16 \& D. Marques (HUFU); Santana do Riacho, 24.X.1974, fl., G. Hatschbach 35278 \& L.F. Ferreira (SPF); Santana do Riacho, 24.X.1974, G. Hatschbach 35295 \& C. Koczicki (MBM); Santana do Pirapama, distrito de São José da Cachoeira, trilha da Senhorinha, $19^{\circ} 00^{\prime} 22^{\prime \prime S} 43^{\circ} 45^{\prime} 20 " \mathrm{~W}, 19.11 .2007$, fl. e fr., V.C. Souza et al. 32814 (BHCB, ESA).

Chromolaena stachyophylla ocorre na Bahia, Goiás, Mato Grosso, Minas Gerais, Paraná, Piauí, São Paulo e Distrito Federal, em áreas de Caatinga, em Cerrado e Mata Atlântica. Na área de estudo pode ser encontrada em campos rupestres. Uma das espécies de mais fácil reconhecimento dentro de Chromolaena, devido à presença de folhas alternas, brácteas externas com ápice obtuso e internas com ápice acuminado, capítulos pequenos (6-7 flores) e sésseis.

\subsection{Chromolaena verticillata R.M.King \&} H.Rob., Phytologia 47: 239. 1980.

Ervas a subarbustos, 0,2-0,3 $\mathrm{m}$ alt. Ramo cilíndrico, multicostado, hirsuto. Folhas opostas ou verticiladas, sésseis; lâminas 0,6-2 cm compr., 0,1 $0,7 \mathrm{~cm}$ larg., lanceoladas, ápice agudo, base decorrente, margem inteira, face adaxial esparsamente hirsuta, face abaxial glandulosopontoada, hifódromas ou paralelódromas. Capitulescência em panículas corimbifomres ou racemos terminais; capítulos com pedúnculo 8,7-37 $\mathrm{mm}$ compr., densamente hirsuto, glandulosopontoado; invólucro campanulado, 5,9-6,6 mm compr., 4,5-6,3 mm larg., 3-5-seriado; brácteas involucrais as externas 2,8-3,1 mm compr., 1,1-1,5 $\mathrm{mm}$ larg., oblongas, ápice truncado, marrom escuro, reflexo, margem esparso-ciliada, as medianas 3,7-4,6 $\mathrm{mm}$ compr., 1,1-1,4 mm larg., obdeltoides, ápice truncado, face adaxial esparsamente hirsuta, margem inteira, as internas 5,2-5,6 mm compr., 0,6-1,1 mm 
larg., estreito-lanceoladas, ápice truncado ou acuminado, face adaxial glanduloso-pontoada, margem inteira. Receptáculo convexo, glabro. Capítulo 16-37 flores; corola com tubo 2,9-3,2 mm compr., glanduloso-pontoado próximo às lacínias; lacínias 0,5$0,7 \mathrm{~mm}$ compr., mamilosas externamente. Anteras com base curtamente sagitada, apêndice apical lanceolado. Ramos do estilete lineares, mamilosos. Cipselas prismáticas, 2,4-3,3 mm compr., 0,5-0,6 mm diâm., glabras; carpopódio assimétrico, anelar. Pápus cerdoso, 2,8-3,3 mm compr.

Material examinado: Minas Gerais, Serra do Cipó, Palacio e Morro do Pilar, II.1953, fl., J. Vidal II-6017 (953) (R); Santana do Riacho, Serra do Cipó, 22.II.2000, bot. e fl., J.E.C. Figueira et al. s.n. (BHCB 50369); Serra do Cipó, entre Palácio e Morro do Pilar, II.1953, fl., J. Vidal II-6017 (953) (R).

Chromolaena verticillata é endêmica de Minas Gerais. Na área de estudo pode ser encontrada em campo limpo. A espécie pode ser reconhecida pela presença de brácteas involucrais com ápice truncado ou reflexo nas externas e medianas obdeltoides com ápice truncado e não reflexo, além da presença de folhas verticiladas.

\subsection{Chromolaena vindex (DC) R.M.King \&} H.Rob., Phytologia 47: 231. 1980.

Ervas, até 0,2 $\mathrm{m}$ alt. Ramo cilíndrico, multicostado, densamente seríceo-tomentoso, glanduloso-pontoado, tricomas glandulares. Folhas alternas, sésseis; lâminas 0,2-1,2 cm compr., 0,1-0,8 $\mathrm{cm}$ larg., ovadas ou lanceoladas, ápice curtomucronado, base aguda, margem inteira às vezes serreada, ambas as faces densamente seríceotomentosas, glanduloso-pontoadas, hifódromas. Capitulescência em panículas corimbiformes; capítulos com pedúnculo 1,9-7,8 $\mathrm{mm}$ compr., densamente seríceo-tomentoso, glanduloso-pontoado, tricomas glandulares; invólucro campanulado, 4,3-9,2 mm compr., 2,6-9 mm larg., (2-)3-seriado; brácteas involucrais com margem inteira, ciliada, as externas 2,9-3,3 mm compr., 0,9-1 mm larg., lanceoladas, ápice agudo, face adaxial tomentosa, glandulosopontoada, as internas 4,9-5 mm compr., 0,7-1,1 $\mathrm{mm}$ larg., linear-lanceoladas, ápice longamente agudo ou acuminado, glanduloso-pontoada no terço superior. Receptáculo convexo, glabro. Capítulo com 30 flores; corola com tubo 3,3-3,5 mm compr., glabrescente na metade superior, esparsamente glanduloso-pontoado; lacínias 0,5-0,9 mm compr., pilosas externamente na porção mediana. Anteras com base sagitada, apêndice apical ovado. Ramos do estilete lineares, mamilosos. Cipselas prismáticas, 2,2-3,4 mm compr., 0,4-0,8 mm diâm., setosas, costas ciliadas; carpopódio assimétrico, anelar. Pápus cerdoso, 3,74,6 $\mathrm{mm}$ compr.

Material examinado: Minas Gerais, Serra do Cipó, fl., III.1962, A.P. Duarte 7974 (RB).
Material adicional examinado: Minas Gerais, São Roque de Minas, Parque Nacional da Serra da Canastra, Vale da nascente do Rio São Francisco, lado das matas, 20.XI.1996, fl., R. Romero 3767 (HUFU).

Chromolaena vindex pode ser encontrada em Goiás, Minas Gerais e Distrito Federal. Na área de estudo ocorre em cerrado. A espécie pode ser reconhecida por apresentar ramos seríceo-tomentosos e com tricomas glandulares, folhas alternas e cipselas setosas.

\section{Disynaphia Hook. \& Arn. ex DC., Prodr. $7(1): 267.1838$.}

Subarbustos ou arbustos eretos, muito ramificados. Ramos cilíndricos, multicostados ou multicostados, pubescentes ou glabros. Folhas alternas, geralmente espiraladas, sesseis a subsésseis; lâminas lineares a oblongas ou oblanceoladas, margem inteira a curto-serreada, nervura principal proeminente. Capitulescência em panículas corimbiformes, capítulos curtopedunculados; invólucro subimbricado, brácteas subinvolucral lanceolada, 2-3(-4)-seriado; brácteas involucrais desiguais. Receptáculo levemente convexo a plano, glabro. Capítulos com 5 flores; corola tubulosa, roxa, rósea ou branca, lacínias triangulares, tão longas quanto largas, mamilosas internamente. Anteras com base hastada, apêndice apical grande, tão longo quanto largo. Ramos do estilete lineares, papiloso ou glabros, com base não alargada. Cipselas prismáticas ou obcônicas, glabras a glandulosas; carpopódio indistinto. Pápus cerdoso, 2-seriado, cerdas unidas na base.

São reconhecidas 16 espécies no gênero, distribuídas pelo Brasil, Argentina, Paraguai e Uruguai (King \& Robinson 1987). O nome Disynaphia se deve à presença de invólucro e pápus 2-seriado, contudo a característica mais notável e diagnóstica do gênero é a disposição espiralada das folhas (King \& Robinson 1987). Na tribo este tipo de filotaxia é comum em Pseudobrickellia, contudo esta apresenta ramos do estilete 'expandidos' e base do estilete alargada e hirsuta, características não encontradas em Disynaphia.

No Brasil existem 14 espécies, da quais nove são endêmicas, distribuídas pelo Cerrado, Mata Atlântica, Pampa e Pantanal. Na área de estudo foi encontrada somente uma espécie.

6.1 Disynaphia praeficta (B.L.Rob.) R.M.King \& H.Rob., Phytologia 32: 284. 1975.

Fig. 2A, B

Arbusto, 1,5 m alt. Ramo cilíndrico, multicostado, glabro. Folhas alternas; espiraladas, sésseis; lâmina 1,9-3 cm compr., 0,5-0,7 cm larg., lanceolada, ápice agudo, base decorrente, margem 
serreada no terço superior, ambas faces glabras, vernicosas, hifódromas. Capitulescência em panículas corimbiformes; capítulos com pedúnculo 2,5-6,3 mm compr., glabro; invólucro cilíndrico, 3,4-4 mm compr., 2,2-3,6 mm larg., 2-seriado; bráctea subinvolucral lanceolada, ápice agudo ou obtuso, margem inteira, face adaxial glanduloso-pontoada próximo ao ápice, brácteas involucrais 2,5-4,7 mm compr., 1,3-1,9 mm larg., lanceoladas ou raramente triangulares, ápice agudo ou obtuso, margem inteira, às vezes ciliada, hialina, glanduloso-pontoada na face adaxial próximo ao ápice. Receptáculo plano-alveolado, glabro. Capítulo com 5(-6) flores; corola com tubo 3,9-4,4 mm compr., glabro; lacínias 0,6-0,7 mm compr., glabras. Anteras com base sagitada, apêndice apical ovado, às vezes curtamente emarginado. Ramos do estilete lineares, papilosos. Cipselas obcônicas, 1,9-2,4 mm compr., 0,5-1 mm diâm., glabras; carpopódio assimétrico, anelar. Pápus 4-4,1 mm compr., cerdas em 2 tamanhos.

Material examinado: Minas Gerais, Santana do Riacho, RPPN Brumas do Espinhaço e Ermo dos Gerais, 12.IX.2012, bot. e fl., C.A. Ferreira Junior et al. 604 (BHZB, HUFU).

Material adicional examinado: Minas Gerais, Diamantina, estrada Diamantina-Conselheiro Mata, km 187, 24.IX.2008, fl., J.N. Nakajima 4984 (HUFU); Estrada Diamantina-Gouveia, ca. 7 km de Diamantina, 23.IX.2010, fl., R. Romero 8383 (HUFU).

Disynaphia praeficta é endêmica do estado de Minas Gerais. Na área de estudo ocorre em campos rupestres. É uma espécie bastante distinta das demais do gênero devido ao hábito arbustivo densamente ramificado, podendo ser classificado como cespitoso (Quaresma 2014), ramos glabros, folhas vernicosas e glabras e ápice das anteras curto-emarginado, contudo sua posição não é certa no gênero devido à ausência de anteras com bases hastadas (King \& Robinson 1987). Segundo avaliação do CNCFLORA a espécie econtra-se em perigo (CNCFlora 2017).

\section{Grazielia R.M.King \& H.Rob., Phytologia 23 (3): 305. 1972.}

Ervas, arbustos ou subarbustos eretos, pouco ou densamente ramificados. Ramos cilíndricos, multicostados ou multiestriados, densamente puberulos, hirtos ou hirsutos. Folhas opostas; curto-pecioladas, lâminas ovadas a lanceoladas, margem serreada, face adaxial com nervuras submersas ou proeminentes. Capitulescência em corimbos densos; capítulos curtopedunculados; invólucro subimbricado, 3-4-seriado; bráctea subinvolucral linear, brácteas involucrais desiguais. Receptáculo plano ou levemente convexo, epaleáceo. Capítulo com 5 flores; corola tubulosa, branca, rosa, lilás ou roxa, lacínias triangulares, mais compridas do que largas. Anteras com apêndice apical mais comprido do que largo. Ramos do estilete lineares, papilosos, espessados ou não no ápice, base não alargada. Cipselas prismáticas ou obcônicas, tricomas glandulares sésseis ou pedunculados; carpopódio obsoleto. Pápus cerdoso, cerdas unidas na base.

O gênero possui 10 espécies ocorrentes no Brasil, Argentina e Uruguai (King \& Robinson 1987). O nome do gênero é uma homenagem à $\mathrm{Dr}^{\mathrm{a}}$-Graziela Maciel Barroso, pesquisadora do Jardim Botânico do Rio de Janeiro. Grazielia é proximamente relacionado à Symphyopappus e Disynaphia pela presença de bráctea subinvolucral diferente das involucrais e capítulos com 5 flores. No entanto Symphyopappus apresenta ramos glabros e densamente estriados e Disynaphia possui suas folhas densamente espiraladas (King \& Robinson 1987).

Para o Brasil existem 10 espécies, sendo sete edêmicas, distribuídas pelo Cerrado e Mata Atlântica. Na área de estudo foi encontrada somente uma espécie.

7.1 Grazielia intermedia (DC.) R.M.King \& H.Rob., Phytologia 23(3): 306. 1972.

Fig. 2C, D

Arbustos, $1 \mathrm{~m}$ alt. Ramo multicostado, tomentoso. Folhas opostas; pecíolo 1,9-4,1 $\mathrm{mm}$ compr., tomentoso; lâminas 1,2-8,8 cm compr., 0,2$2,2 \mathrm{~cm}$ larg., discolores, lanceoladas, ápice acuminado, base atenuada, margem serreada, face adaxial glabra, glanduloso-pontoada, face abaxial, esparsamente hirsuta, glanduloso-pontoada, densamente hirsuta nas nervuras, eucamptódromas. Capitulescência em panículas corimbiformes; capítulos com pedúnculo $0,5-1,8 \mathrm{~mm}$ compr., tomentoso; invólucro cilíndrico, 3,4-5 mm compr., 1,6-2,2 mm larg., 3-seriado; bráctea subinvolucral linear, ápice agudo, face adaxial esparso-tomentosa, brácteas involucrais 2,8-4,6 $\mathrm{mm}$ compr., 1,2-1,6 $\mathrm{mm}$ larg., ápice agudo ou obtuso, ciliado, margem inteira, ciliada, face adaxial tomentosa, externas ovadas, internas oblongas. Receptáculo plano, glabro. Capítulo com 5 flores; corola com tubo 2,3-2,7 mm compr., glabro; lacínias 0,5-0,8 mm compr., glabras, tricomas curtos externamente. Anteras com apêndice apical ovado, base sagitada. Ramos do estilete lineares, papilosos. Cipsela obcônica, levemente estipitada, 0,9-1,4 mm compr., 0,2-0,4 mm diâm., glabra; carpopódio assimétrico, anelar. Pápus cerdoso, 2,1-3 mm compr.

Material examinado: Minas Gerais, Serra do Cipó, cerca de $153 \mathrm{Km}$ ao norte de Belo Horizonte, fl., 17.II.1968, H.S. Irwin et al. 20344. (RB 150421); Conceição do Mato Dentro, Capão Redondo, Fazenda Boa Esperança, margem direita da rodovia MG 010 Belo Horizonte-Conceição do Mato Dentro, km 145, 13.II.1996, bot. e fl., N. Roque et al. 148 (HUFU, SPF).

Grazielia intermedia pode ser encontrada em Goiás, Mato Grosso, Minas Gerais, Paraná, Rio de Janeiro, Rio grande do Sul, Santa Catarina, São Paulo e Distrito Federal, em áreas de Cerrado e Mata Atlântic. Na área de estudo pode ser encontrada em margem de córregos e riachos. A espécie pode ser reconhecida por apresentar suas folhas fortemente 
discolores, cipselas levemente rostradas e lacínias com tricomas curto-pedunculados glandulares.

Assemelha-se à G. serrata (Spreng.) R.M.King \& H.Rob. por apresentarem lâminas fortemente serreadas e lanceoladas e capitulescência em panículas corimbiformes congestas, contudo $G$. serrata apresenta suas lâminas tomentosas e peninérveas ou craspedódromas ( $v s$. lâminas glabras e esparso-hirsutas e eucamptódromas).

\section{Heterocondylus R.M.King \& H.Rob. Phytologia 24(5): 389-390. 1972.}

Subarbusto ou arbusto, ereto ou semiprostrado, eventualmente arbustos escandentes, pouco ou muito ramificados. Ramo cilíndrico, levemente estriado, pubescente a tomentoso, muitas vezes com tricomas glandulares. Folhas inteiras, concentradas na base ou no ápice da planta ou distribuídas por todo o ramo, opostas, alternas ou verticiladas, ou alternas na porção superior dos ramos, sésseis ou pecioladas. Capitulescências terminais, paniculiformes, invólucro cilíndrico ou campanulado, brácteas involucrais persistentes, 4-6 séries, subimbricadas ou eximbricadas. Receptáculo plano, glabro ou piloso. Flores 20 a 110, róseas, corola infundibuliforme, glabra, lobos triangulares, face externa com ou sem tricomas glandulares ou glândulas sésseis. Antera com apêndice apical agudo ou arredondado, base decorrente ou arredondada. Estilete com base alargada, pilosa ou glabra, ramos rosados, cilíndricos ou levemente clavados, papilosos com papilas muito curtas, ou mamilosos. Cipsela turbinada, prismática ou obconica, (4-)5 costada, levemente estipitada, carpopódio cilíndrico, assimétrico. Pápus unisseriado, cerdas escabras, persistentes, esbranquiçadas, unidas na base.

São reconhecidas 12 espécies no gênero, distribuídas na América do Sul e Central (King \& Robinson 1987). O gênero foi estabelecido por King \& Robinson, em 1972, com base no carpopódio assimétrico com a camada basal de células espessada.

No Brasil existem seis espécies, sendo quatro endêmicas, distribuídas em todas as regiões do país. Fernandes (2014) cita como ocorrência do gênero, sendo: florestas, áreas campestres e solos encharcados. $\mathrm{Na}$ área de estudo, ocorrem principalmente em campo limpo.

\section{Chave para as espécies de Heterocondylus}

1. Folhas com pecíolo alado distribuídas ao longo do ramo; capítulos com até 35 flores .....8.1 H. alatus

1'. Folhas sem pecíolo alado, concentradas próximo à base; capítulos com mais de 35 flores (até 71)
8.1 Heterocondylus alatus (Vell.) R.M.King \& H.Rob., Phytologia 49: 5. 1981.

Fig. 2EC, $\mathrm{F}$

Subarbustos, 0,5 m alt. Ramos multicostados, seríceos, tricomas glandulares. Folhas opostas; pecíolo alado $2-3 \mathrm{~mm}$ compr.; lâminas $0,5-6,1 \mathrm{~cm}$ compr., 0,2-1,8 cm larg., elípticas a largo-lanceoladas, ápice mucronado ou às vezes curtamente apiculado, base amplexicaule, margem repanda, ambas faces esparsamente seríceas, eucamptódromas. Capitulescência em panículas de cimeiras; capítulos com pedúnculo 1,4-11 $\mathrm{mm}$ compr., densamente coberto por tricomas glandulares; invólucro campanulado, 3,2-8,6 mm compr., 4,2-11,1 mm larg., 3-5-seriado; brácteas involucrais com ápice agudo, margem inteira, tricomas glandulares, as externas 2,1$3,2 \mathrm{~mm}$ compr., $0,8-1,2 \mathrm{~mm}$ larg., lanceoladas, as medianas 3,7-5,7 mm compr., 1,1-1,3 $\mathrm{mm}$ larg., lanceoladas, as internas 7,7-8,7 mm compr., 0,8-1,3 $\mathrm{mm}$ larg., oblongo-lanceoladas. Receptáculo plano, piloso. Capítulo com 20-35 flores; corola com tubo 4,7-5,3 mm compr., glabro; lacínias $0,6 \mathrm{~mm}$ compr., glabras. Anteras com base arredondada, apêndice apical ovado. Ramos do estilete lineares, mamilosos, estilopódio alargado, globoso, glabro. Cipsela obcônica, 1,2-2,8 mm compr., 0,4-0,5 mm diâm., tricomas glandulares; carpopódio assimétrico, levemente cilíndrico. Pápus cerdoso, 4,1-4,9 mm compr.

Material examinado: Minas Gerais, Santana do Riacho, campo próximo à sede do IBAMA do Alto do Palácio, 1.X.1991, bot. e fl., J.R. Pirani et al. CFSC 12705 (HUFU, SPF); Santana do Riacho, RPPN Brumas do Espinhaço e Ermo dos Gerais, 11.IX.2012, fl. e fr., C.A. Ferreira Junior et al. 560 (BHZB, HUFU); Conceição do Mato Dentro, Capão Redondo, Fazenda Boa Esperança - margem esquerda da rodovia MG 010, km 145, 13.II.1996, bot., fl. e fr., N. Roque et al. 159 (HUFU, SPF).

Heterocondylus alatus é encontrada na Bahia, Espírito Santo, Goiás, Mato Grosso, Mato Grosso do Sul, Minas Gerais, Paraná, Rio de Janeiro, Rio Grande do Sul, Santa Catarina, São Paulo e Distrito Federal (Fernandes, 2014). A espécie é facilmente distinta das demais pela presença de pecíolo alado.

8.2 Heterocondylus pumilus (Gardner) R.M.King \& H.Rob., Phytologia 24: 391. 1972.

Subarbustos, ca. $0,3 \mathrm{~m}$ alt. Ramo com tricomas glandulares densamente hirsutos. Folhas opostas; basais, sésseis; lâminas 1,8-5,8 cm compr., $0,4-1,6 \mathrm{~cm}$ larg., estreito-elípticas, às vezes ovadas ou lanceoladas, ápice agudo ou curto-mucronado, base decurrente, margem serreada, ambas faces com tricomas multicelulares e glandulares, camptódromas. Capitulescência em racemos; invólucro campanulado, 
8,3-10,6 mm compr., 9,7-16,9 mm larg., 3(-4)-seriado; brácteas involucrais $3,1-8,8 \mathrm{~mm}$ compr., 1,1-1,6 mm larg., ápice acuminado, levemente arroxeado, margem ciliada, face adaxial com tricomas glandulares, externas ovado-lanceoladas, medianas e internas oblongo-lanceoladas. Receptáculo plano-alveolado, glabro. Capítulos com até 71 flores; corola com tubo 3,8-4,5 mm compr., glabro; lacínias 0,6 mm compr., glabras. Anteras com base arredondada, apêndice apical lanceolado. Ramos do estilete lineares, papilosos. Cipsela prismática, 2,7-3,4 mm compr., 0,5 $\mathrm{mm}$ diâm., costas ciliadas, tricomas glandulares entre as costas; carpopódio assimétrico, anelar. Pápus com cerdas unidas na base formando anel, 4,5-5 mm compr.

Material examinado: Minas Gerais, Santana do

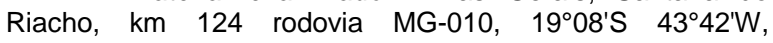
8.VI.2002, fl. e fr., M.F. Calió et al. 5 (HUFU, SPF); Santana do Riacho, além da sede do IBAMA do Palacio, 1.V.1993, fl., N. Roque \& J.R. Pirani CFSC 13052 (HUFU, SPF); Santana do Riacho, rodovia Belo Horizonte-Conceição do Mato Dentro, Km 118, 9.VI.2002, fl. e fr., J.R. Pirani et al. 5088 (HUFU, SPF); Serra do Cipó, estrada para Conceição do Mato Dentro, próximo ao trevo para Morro do Pilar, 19¹3'34"S 4330'20"W, 1.VII.2015, bot. e fl., F.L. Contro et al. 96 (HUFU); Serra do Cipó, estrada para Conceição do Mato Dentro, cerca de $15 \mathrm{~km}$ de Cardeal Mota, 30.VI.2015, bot. e fl., F.L.Contro et al. 83 (HUFU); Serra do Cipó, estrada para Conceição do Mato Dentro, Alto do Palácio, 19¹5'79"S 43³2'10"W, 29.VI.2015, bot. e fl., F.L. Contro et al. 71 (HUFU); Santana do Riacho, rodovia Belo HorizonteConceição do Mato Dentro, próximo à bifurcação para Morro

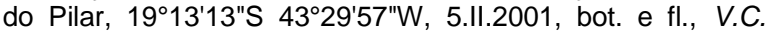
Souza et al. 25103 (ESA, HUFU); PARNA Serra do Cipó, MG 010 a $33 \mathrm{Km}$ da ponte do Rio Cipó, antigo km 140, $19^{\circ} 13^{\prime 2} 23^{\prime \prime S} 43^{\circ} 30^{\prime} 7 " W, 23 . V .2009$, bot. e fl., M.M. Saavedra et al. 865 (RB, SPF); Congonhas do Norte, Serra da Moeda, 15.VIII.1998, fl. e fr., R.C. Forzza et al. 970 (SPF); Serra do Cipó, estrada para Morro do Pilar, aproximadamente km 205, 1.VII.2015, fl. e fr., F.L. Contro et al. 122 (HUFU).

Heterocondylus pumilus pode ser encontrada em Goiás, Minas Gerais, Paraná, Rio de Janeiro e São Paulo, ocorrendo no domínio do Cerrado. Na área de estudo é encontrada em campo limpo e áreas de campo rupestre. A espécie é facilmente distinta por apresentar as folhas concentradas próximo à base e por possuir seus ramos cobertos por tricomas glandulares pedunculados, invólucro e ramos vináceos (Fernandes 2014).

\section{Koanophyllon Arruda, Trav. Brazil 495-496. 1816.}

Arbustos ou arvoretas, raramente lianas e trepadeiras, pouco ou muito ramificadas. Ramos cilíndricos, estriados. Folhas opostas, raramente alternas, pecioladas; lâmina lanceolada a elíptica, base aguda, truncada ou cordada, margem inteira ou serreada, craspedódroma a paralelódroma.
Capitulescência em panícula piramidal a corimbosa, pedúnculos curtos. Invólucro eximbricado a fortemente subimbricado, 2-4-seriado, brácteas involucrais caducas na maturação. Receptáculo plano a levemente convexo, epaleaceo. Capítulo com 5-20 flores; corola branca a amarela-esverdeada, raramente violeta, funeiforme, lacínias triangulares, tricomas glandulares ou tricomas externamente. Anteras com colar cilíndrico, apêndices mais largos do que longos, margem apical plana a recurvada. Ramos do estilete papilosos no ápice, base do estilete não alargada, glabra. Cipsela prismática, 5-costada, costas setosas, com ou sem glândulas. Pápus cerdoso, 1seriado, cerdas com ápice agudo.

King \& Robinson (1987) reconhecem 114 espécies para o gênero, distribuídas no Paraguai e Sul do Brasil, Nordeste do Andes, America Central e Mexico. No Brasil existem 14 espécies, das quais dez são endêmicas, distribuídas pela Amazônia, Caatinga, Cerrado, Mata Atlântica e Pantanal. Koanophyllon é o maior gênero de Critoniinae, e pode ser caracterizado pela presença de corola com tubo cilíndrico, lacínias curto-triangulares e pápus robusto e persistente.

Koanophyllon é o centro de um grupo complexo de espécies, que envolve alguns gêneros próximos, como Eupatoriastrum Greenm., que possui páleas e capítulos com numerosas flores e Fleishmanniopsis, caracterizado por apresentar corola curta e base do estilete alargada (King \& Robinson 1987). Na delimitação e estabelecimento do gênero King \& Robinson (1976) relacionam a proximidade de Koanophyllon com outros gêneros, através de caracteres pontuais, como folhas curto-pecioladas, também presentes em Hebeclinium DC. e folhas com pontoações glandulosas, característica de Critonia P. Browne.

9.1 Koanophyllon adamantium (Gardner) R.M.King \& H.Rob., Phytologia 32: 254. 1975.

Fig. 2G, J

Arbustos, $0,5 \mathrm{~m}$ alt. Ramos tomentosos, tricomas glandulares. Folhas alternas; pecíolo 2,2-11,3 mm compr., tomentoso, tricomas glandulares; lâminas 1,4-5,2 cm compr., $1-3,4 \mathrm{~cm}$ larg., ovadas a amplo-elípticas, ápice curtamente mucronado, base aguda, margem levemente denteada, face adaxial setosa, glanduloso-pontoada, face abaxial tomentosa, glanduloso-pontoada, craspedódromas. Capitulescência em tirso; capítulos com pedúnculo 4,7-7,3 mm compr., hirsuto, tricomas glandulares; invólucro campanulado, eximbricado, 6,4-8,2 mm compr., 4,8-5,8 mm larg., 2-seriado; brácteas involucrais 2,3-5,4 mm compr., $0,4-0,8 \mathrm{~mm}$ larg., lineares, ápice acuminado, face adaxial hirsuta, glanduloso-pontoada. Receptáculo planoalveolado, glabro. Capítulos com 14-17 flores; corola com tubo 3,5-3,9 mm compr., glabro; lacínias $0,4 \mathrm{~mm}$ 


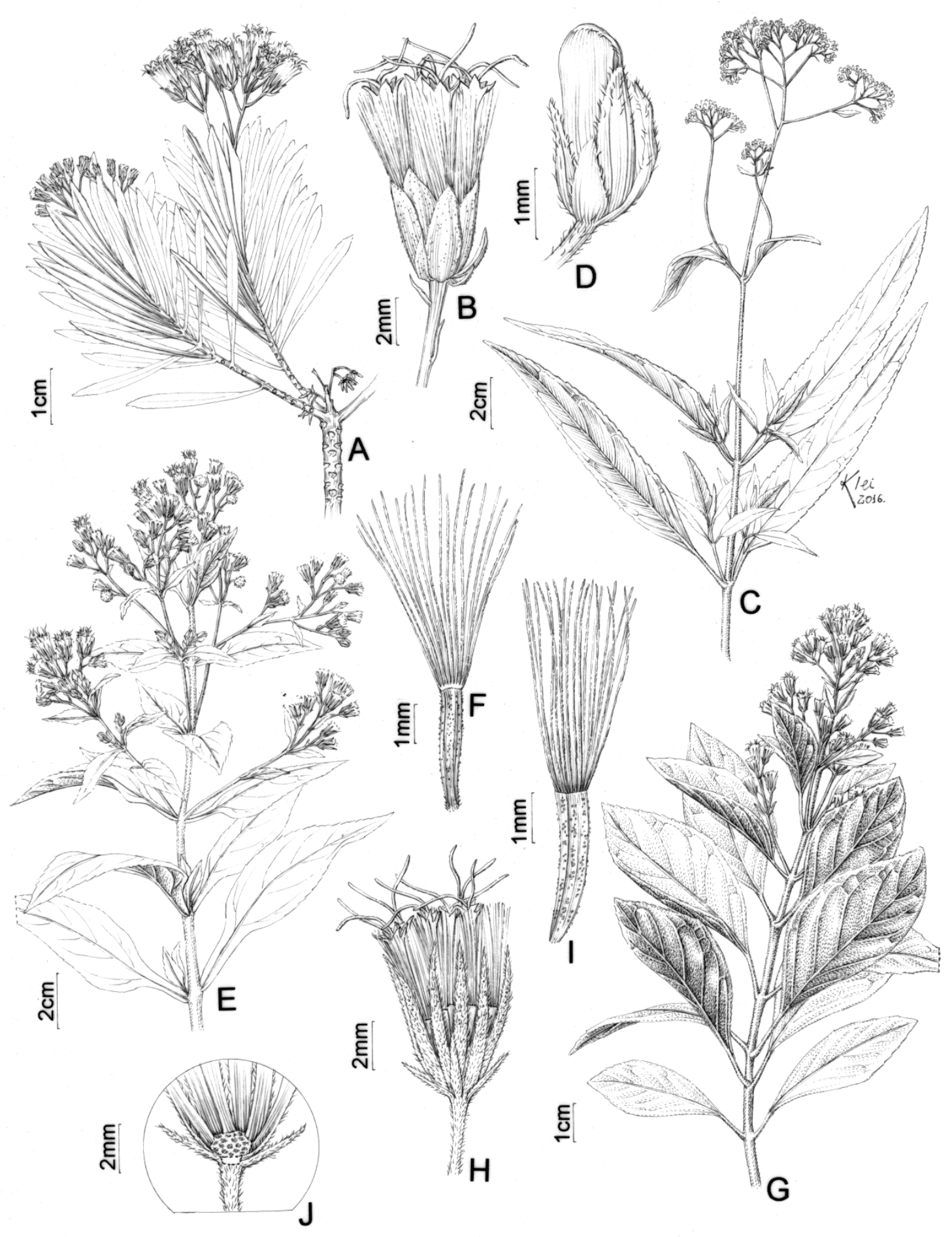

Fig. 2: A-B. Disynaphia praeficta (B.L.Rob.) R.M.King \& H.Rob. A. Ramo. B. Invólucro. C-D. Grazielia intermedia (DC.) R.M.King \& H.Rob. C. Ramo. D. Invólucro. E-F. Heterocondylus alatus (Vell.) R.M.King \& H.Rob. E. Ramo. F. Cipsela e pápus. G-J. Koanophyllon adamantium (Gardner) R.M.King \& H.Rob. G. Ramo. H. Invólucro. I. Cipsela e pápus. J. Detalhe do receptáculo. (A.; C. R.Romero 7579; E. R.Romero 2439; G. F.L.Contro 103). 
compr., ciliadas, tricomas glandulares. Anteras com base arredondada, apêndice apical lanceolado. Ramos do estilete lineares, espessados no ápice. Cipsela estipitada, 3,3-3,5 mm compr., 0,5-0,6 mm diâm., glanduloso-pontoada, esparsamente hirsuta; carpopódio simétrico, anelar. Pápus 4,5-5,1 mm compr., cerdas concrescidas na base formando anel.

Material examinado: Minas Gerais, Santana do Riacho, Km 125 rodovia Belo Horizonte-Conceição do Mato Dentro, próximo à estatua do Velho Juca, 31.VIII.1991, fl. e fr., J.R. Pirani et al. 12696 (HUFU, SPF); estrada para Conceição do Mato Dentro, próximo ao trevo para Morro do Pilar, 19॰13'34"S 4330'20"W, 1.VII.2015, fl. e fr., F.L. Contro et al. 103 (HUFU); Santana do Riacho, Fazenda Cachoeira da Capivara, 4.VII.1996, fl. e fr., V.C. Souza et al. 11651 (ESA, HUFU); Conceição do Mato Dentro, Serra da Ferrugem, 16.VI.2008, fl. e fr., E.A.E. Guarçoni 1359 \& M.A. Sartori (ESA, HUFU); Conceição do Mato Dentro, Serra do Sapo, 16.VI.2008, fl. e fr., E.A.E. Guarçoni 1340 \& M.A. Sartori (ESA, HUFU); Santana do Riacho, PARNA Serra do Cipó, $3 \mathrm{~km}$ da portaria do IBAMA do Alto do Palácio, 16.VIII.1992, fl. e fr., M. Pereira 822 \& M. Lucca (BHCB); Serra do Cipó, km 141, 6.VIII.1936, fl. e fr., W.A. Archer \& Mello Barreto 4946 (BHCB, BHMH).

Koanophyllon adamantium distribui-se pelos estados da Bahia, Espírito Santo, Mato Grosso do Sul, Minas Gerais, Rio de Janeiro, São Paulo e abrange os domínios da Caatinga, Cerrado e Mata Atlântica. Na área de estudo é encontrada, principalmente em campo rupestre.

A espécie é facilmente reconhecida por apresentar sua capitulescência em panículas piramidais, invólucro 2-seriado e fortemente eximbricado e suas lâminas com ambas as faces tomentosas. Nakajima (2001) cita a semelhança desta espécie com Koanophyllon tinctorium Arruda, porém esta apresenta folhas e ramos glabros e capitulescência corimbiforme. 10. Mikania Willd., Sp. Pl., ed. 4,
3 (3): 1481. 1742 .

Plantas perenes, volúveis, decumbentes ou eretas. Ramo cilíndrico ou hexagonal, estriado, sulcado, raras vezes alado, glabro ou piloso. Folhas opostas ou verticiladas, sesseis ou pecioladas, com ou sem estípulas interpeciolares, lanceoladas, cordiformes a hastadas, glabras ou com tricomas simples e/ou glandulares, margem inteira a profundamente dividida, base cuneada, cordiforme ou hastada; ápice arredondado a caudado, paralelódromas ou craspedódromas. Capitulescências em corimbos, panículas tirsoides, de glomérulos, ou espiciformes. Capítulos com quatro flores; isomorfos, sésseis ou pedunculados, glabros ou pilosos. Bráctea subinvolucral persistente, junto das brácteas involucrais, um pouco mais abaixo ou na base do pedúnculo. Brácteas involucrais 4 , duas externas e duas internas, ovaladas a lanceoladas, ápice agudo ou obtuso, pilosas, glabras ou ciliadas no ápice. Corola tubulosa, raramente bilabiada, esbranquiçada, diferenciada em tubo, limbo e cinco lacínias. Anteras obtusas na base, apêndices apicais ovalados. Estilete com ramos lineares ou clavados, obtusos no ápice, papilosos, nectário na base. Cipsela 5-costada, raramente dez, glabra ou pilosa, muitas vezes com tricomas glandulares. Pápus cerdoso, 1-seriado, cerdas barbeladas, lisas ou levemente escabras, brancas a rosadas.

O gênero apresenta 403 espécies distribuídas nas regiões tropicais e subtropicais da America (Ritter \& Miotto 2005). No Brasil existem 203 espécies, sendo 142 endêmicas, distribuídas em todos os estados brasileiros.

O gênero é facilmente reconhecível e distinto dos demais da tribo por apresentar capítulo com 4 brácteas involucrais e 4 flores. Na área de estudo foram encontradas 28 espécies no gênero.

Chave para as espécies de Mikania

1. Lianas.

2. Folhas cordadas ou ovadas com base cordada.

3. Folha com venação camptódroma; capitulescência em tirsos patentes

3'. Folhas com venação craspedodroma ou paralelodroma; Capitulescência em corimbos (racemos ou panículas).

4. Folhas com pecíolo glanduloso-pontoado, margem inteira, ápice acuminado 10.5 M. cordifolia 4'. Folhas com pecíolo sericeo, margem denteada a irregular, ápice mucronado 10.12 M. micrantha

2'. Folhas elípticas ou lanceoladas com base aguda, cuneada, obtusa ou cordada.

5. Capitulescência em tirsos, capítulos sésseis

10.1 M. acuminata

5'. Capitulescência em panículas (corimbiformes, piramidais ou tirsoides); capítulos pedunculados.

6. Folhas com nervação camptódroma, pecíolo incano, margem inteira; brácteas com ápice obtuso

10.9 M. lindbergii

6'. Folhas com nervação paralelódroma, pecíolo hirsuto ou tomentoso, margem serreada ou inteira; brácteas com ápice arredondado.

7. Capitulescência em panículas umbeliformes ..10.20 M. phaeoclados

7'. Capitulescência em panículas tirsoides

1'. Ervas, subarbustos ou arbustos.

8. Plantas escandentes ou decumbentes.

9. Capitulescência em tirsos, racemos ou espigas. 
10. Folhas com nervação paralelodromas, lâmina elíptica

10.17 M. obtusata

10'. Folhas com nervação broquidodroma, camptódroma ou peninérvea, lâmina lanceolada, oblongolanceolada ou ovada.

11. Plantas hirsuto-tomentosas; capitulescência em tirsos

11'. Plantas glabras ou glanduloso-pontoadas; capitulescência em racemos ou espigas.

12. Folhas concolores, margem não revoluta; brácteas subinvolucrais lineares a linearlanceoladas, ápice agudo a acuminado, glabrescente a seríceas .............................10.22 M. psilostachya

12'. Folhas discolores, margem revoluta; brácteas subinvolucrais oblongas a oblongo-

lanceoladas, ápice arredondado a obtuso, glabrescente .......................................... 10.24 M. ramosissima

9'. Capitulescência em panículas corimbiformes.

13. Lâminas foliares não glanduloso-pontoadas; bráctea involucral com ápice longo agudo a acuminado; cipsela glabra

13'. Lâminas foliares glanduloso-pontoadas; bráctea involucral com ápice cuspidado; cipsela glandulosa

10.4 M. conferta tas eretas.

14. Folhas com margem denteada, 3 dentes pronunciados ao longo da margem 10.2 M. banisterieae

Folhas com margem inteira, crenada ou serreada, mas não com dentes pronunciados.

16. Folhas sésseis.

17. Folhas tomentosas

17'. Folhas estrigosas ou escabras.

18. Folhas com margem crenada, face adaxial estrigosa

18'. Folhas com margem inteira, face adaxial glabra, esparso glandulosa

16'. Folhas pecioladas.

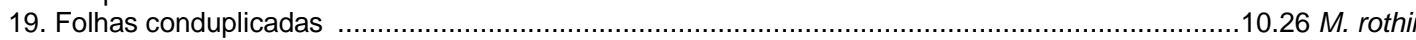

19'. Folhas planas.

20. Lâminas foliares sagitadas.

21. Capitulescência em panículas umbeliformes; brácteas involucrais avermelhadas a arroxeadas, ápice cuspidado; receptáculo fimbriado ........................................... $10.3 \mathrm{M}$. cipoensis

21'. Capitulescência em panículas corimbiformes; brácteas involucrais castanhas, ápice apiculado; receptáculo glabro ....................................................................10.18 M. officinalis

20'. Lâminas foliares elípticas, largo-elípticas, ovadas ou lanceoladas, mas não sagitadas.

22. Capitulescência em tirsos ou panículas de dicasio.

23. Folhas broquidódromas

23'. Folhas paralelódromas.

24. Ramos velutíneos; lâminas foliares largo-elípticas a ovadas

24'. Ramos glabros ou setosos próximos a capitulescência; lâminas foliares

largo-elípticas a ovadas

10.10 M. luetzelburgii

Meurocaula

sessilifolia

2. Capitulescência em panículas corimbiformes ou umbeliformes.

25. Panículas umbeliformes.

26. Ervas, ramos híspido-escabros; folhas com margem crenada, paralelódromas; brácteas involucrais oblongas; corola glanduloso-pontoada; cipsela glanduloso-pontoada

10.15 M. nummularia 10.28 M. warmingii

26. Arbustos, ramos tomentosos; folhas com margem serreada ou inteira, broquidoó parvifolia brácteas involucrais oblongo-lanceoladas; corola glabra; cipsela glabra .......10.7 M. itambana 25'. Panículas corimbiformes.

27. Pápus alvo; plantas glabras

$10.25 M$. reticulata

27'. Pápus alaranjado ou ferrugíneo; plantas pilosas (hirsutas, tomentosas ou

hirsuto-tomentosas).

28. Ramos hirsutos; brácteas involucrais com ápice agudo; corola com lacínias glabras; cipselas hirsutas

28'. Ramos tomentosos; brácteas involucrais com ápice curtomucronado; lacínias papilosas; cipselas glabras

10.23 M. purpurascens .. 10.8 M. leiolaena 1838.

10.1 Mikania acuminata DC., Prodr. 7 (1): 270.

Lianas. Ramo cilíndrico, multicostado, glabro. Folhas opostas; pecíolo 2,1-8,5 mm compr., glabro; lâmina 7,6-38,7 mm compr., 2,3-12,2 mm larg., lanceolada, ápice agudo ou acuminado, base aguda, margem inteira, revoluta, face adaxial glabra, face abaxial glanduloso-pontoada, broquidódromas, peninérveas ou craspedódromas. Capitulescência em tirsos; capítulos sésseis, invólucro campanulado, 2,53,3 mm compr., 2,1-2,5 $\mathrm{mm}$ larg., bráctea subinvolucral oblonga, ápice obtuso, margem inteira, ciliada, brácteas involucrais 1,8-2,8 mm compr., 0,7-
0,9 mm larg., oblongas, ápice truncado ou obtuso, margem inteira, às vezes hialina, ciliada, glabras. Receptáculo plano, glabro. Corola glabra, tubo 0,9-1,3 $\mathrm{mm}$ compr.; lacínias 0,7-1,3 mm compr. Anteras com base arredondada, apêndice apical ovado. Ramos do estilete lineares, tricomas glandulares. Cipselas obcônicas, 1,1-1,7 mm compr., 0,3-0,4mm diâm., glabrescentes, carpopódio ausente ou indistinto. Pápus 1,9-2,3 mm compr., cerdas com ápice espessado.

Material examinado: Minas Gerais, Jaboticatubas, 5.VIII.1972, fl., G. Hatschbach 29913 (MBM); Jaboticatubas, Serra da Meia Libra, 18.XI.1942, Mendes Magalhães 2708 (BHCB, BHMH). 
Material adicional examinado: Minas Gerais, São Roque de Minas, PARNA da Serra da Canastra, 20¹0'17"S 46³9'52"W, 14.VII.1997, bot., fl. e fr., J.A. Lombardi 1869 (MBM).

Mikania acuminata ocorre em Goiás, Minas Gerais, Rio de Janeiro, São Paulo e Distrito Federal, em áreas de Cerrado e Mata Atlântica. Na área de estudo pode ser encontrada em cerrado s.s. A espécie pode ser reconhecida por apresentar folhas com ápice geralmente acuminado e venação principalmente broquidódroma e ramos do estilete com tricomas glandulares.

É similar à $M$. oblongifolia, contudo esta apresenta cipselas rostradas e hirsutas, folhas vernicosas e com venação camptódroma (vs. cipselas obcônicas e glabrescentes, folhas não vernicosas e venção broquidódroma). Também se assemelha à $M$. ramosissima pela presença de folhas lanceoladas ou oblongo-lanceoladas e capitulescência, que às vezes pode se apresentar em forma de tirsos ou racemos.

10.2 Mikania aff. banisteriae DC., Prodr. 5: 193. 1836.

Subarbusto escandente. Ramo cilíndrico, multicostado, hirsuto, glanduloso-pontoado. Folhas opostas; pecíolo 3,6-19,4 mm compr., densamente hirsuto-tomentoso; lâmina 16,8-77,3 mm compr., 4,462,3 mm larg., ovada a largo-lanceoladas, ápice acuminado, base cordada, margem inteira, às vezes com dentículos, face adaxial estrigosa, face abaxial densamente hirsuto-tomentosa, paralelódroma ou camptódroma. Capitulescência em panículas corimbiformes; capítulos com pedúnculo 0,6-1,2 mm compr., densamente hirsuto; invólucro campanulado, 2,6-5,5 mm compr., 1,8-3,3 mm larg., bráctea subinvolucral 2-2,6 mm compr., 0,9-1,6 mm larg., lanceoladas, ápice acuminado, margem ciliada, inteira, às vezes hialina, face adaxial hirsuta; brácteas involucrais 4-4,3 $\mathrm{mm}$ compr., 0,9-1,1 mm larg., oblongo-lanceoladas, ápice longo-agudo a acuminado, às vezes ciliado, margem inteira, ápice serrilhado, às vezes hialina. Receptáculo plano, glabro. Corola com tubo 0,6-0,8 mm compr., glabro; limbo 1,5-1,6 mm compr., glabro; lacínias 0,7-0,9 mm compr., hirsutas externamente. Anteras com base arredondada, apêndice apical lanceolado, ápice obtuso. Ramos do estilete lineares, papilosos. Cipsela obcônicas, 1-1,3 mm compr., 0,1-0,2 mm diâm., glabra; carpopódio indistinto. Pápus 2,5-3,2 mm compr.

Material examinado: Minas Gerais, Santana do Riacho, estrada de Belo Horizonte-Conceição do Mato Dentro, cerca de $5 \mathrm{~km}$ após a bifurcação para Morro do Pilar, 5.VII.1996, bot., fl. e fr., V.C. Souza et al. 11573 (ESA, HUFU); Serra do Cipó, estrada para Morro do Pilar, aproximadamente km 205, 1.VII.2015, bot. e fl., F.L. Contro et al. 124 (HUFU).

Mikania banisterieae encontra-se distribuída pelos estados do Acre, Amazonas, Goiás, Mato
Grosso, Minas Gerais, Pará, Roraima e Distrito Federal, na Amazônia e Cerrado. Na área de estudo pode ser encontrada em borda de mata. Nakajima (2000) compara esta espécie à M. conferta Gardner, contudo esta se diferencia pela presença de ramos hirsuto-tomentosos, folhas híspidas e corola glabra (vs. ramos hirsutos e glanduloso-pontoados, folhas hirsutas e tomentosas e corola com lacínias hirsutas).

10.3 Mikania cipoensis G.M.Barroso, Arch. Jard. Bot. Rio de Janeiro, 16: 309. 1959.

Subarbustos a arbustos, 0,6-1 m alt, eretos. Ramo cilíndrico, multiestriado, estrigoso, avermelhado ou incano. Folhas opostas ou verticiladas; discolores, pecíolo 1,1-5,9 mm compr., densamente estrigoso, glanduloso-pontoado, lâminas 2-11,9 mm compr., 1,5-11,2 mm larg., sagitadas, ápice curto mucronado, base sagitada, margem inteira, levemente revoluta, face adaxial esparsamente serícea, face abaxial velutínea, densamente glanduloso-pontoada, serícea nas nervuras, paralelódromas ou actinódromas. Capitulescência em panículas umbeliformes; capítulos com pedúnculo 0,8-3 $\mathrm{mm}$ compr., densamente seríceo; invólucro cilíndrico, 3,4-6,5 mm compr, 1,9-3 $\mathrm{mm}$ larg.; bráctea subinvolucral lanceolada, ápice agudo a cuspidado, margem inteira, brácteas involucrais 5,7-7,6 mm compr., 1,5-2 mm larg., lanceoladas, avermelhadas a arroxeadas, ápice cuspidado, margem hialina, ciliada no terço superior, face adaxial estrigoso-serícea, glanduloso-pontoada. Receptáculo plano, fimbriado. Corola com fauce alargada, tubo 2,9-3,3 mm compr.; lacínias 1,1-1,3 $\mathrm{mm}$ compr., glanduloso-pontoadas. Anteras com base sagitada, apêndice do conectivo ovado. Ramos do estilete lineares. Cipselas obcônicas, 1,3-3,2 mm compr., 0,4-0,6 mm diâm., glabras, carpopódio ausente. Pápus 5,1-5,5 mm compr., cerdas concrescidas na base formando anel.

Material examinado: Minas Gerais, Santana do Riacho, Km 127 estrada para Conceição do Mato Dentro, Alto do Palácio, 12.V.1987, fl., R. Marquete, R.H.P. Andreata \& Talita 27 (RB); km 132 (ca. $153 \mathrm{~km}$ de Belo Horizonte), 16.II.1968, fl. e fr., H.S. Irwin et al. s.n. (RB 150481); estrada Lagoa Santa-Conceição do Mato Dentro, 28.Il.1995, fl. e fr., N.M. Castro 376 (HUFU); Serra do Cipó, km 125, 1.III.1981, fl., N.M. Castro s.n. (HUFU 133); Serra do Cipó, km 137, I.1981, bot. e fl., N.M. Castro s.n. (HUFU 238); estrada para Conceição do Mato Dentro, aproximadamente $\mathrm{km} \mathrm{125,}$ 19॰14'02"S 43³0'34"W, 30.VI.2015, bot. e fl., F.L. Contro et al. 90 (HUFU); Serra do Cipó, estrada Lagoa SantaConceição do Mato Dentro, km 121, 28.II.1995, fl., N.M. Castro 376 (HUFU); Serra do Cipó, km 137, I.1981, bot. e fl., N.M. Castro s.n. (HUFU 0238); Serra do Cipó, km 125, 1.III.1981, fl. e fr., N.M. Castro s.n. (HUFU 133); Jaboticatubas, 18.I.1972, bot. e fl., G. Hatschbach et al. 28789 (MBM); Jaboticatubas, 9.I.2001, bot. e fl., K.E. Quadros s.n. (FURB 505, MBM 340720); Serra do Cipó, km 111, 30.III.1949, fl. e fr., G.M. Magalhães 5234 (BHCB); Serra do Cipó, km 138, 20.IV.1953, fl. e fr., Mendes Magalhães 5915 (BHCB); Santana do Riacho, 23 km após o córrego Soberbo em Cardeal Mota, margem da MG 010, área a 
esquerda da pista, $19^{\circ} 14^{\prime} 56 " \mathrm{~S} 43^{\circ} 31^{\prime} 48^{\prime \prime} \mathrm{W}, 1$.VI.2011, fl. e fr. B.M. Carvalho \& J.A.N. Batista 85 (BHCB).

Mikania cipoensis é endêmica de Minas Gerais. Na área de estudo pode ser encontrada em campos rupestres. A espécie é muito parecida com $M$. officinalis pelo hábito e folhas ovadas com base cordada ou sagitada, contudo esta apresenta suas capitulescências em panículas corimbiformes, pápus alvo e hábito arbustivo densamente ramificado, enquanto $M$. cipoensis possui capitulescência em racemos de dicásio ou dicásios corimbiformes, pápus alaranjado e hábito subarbustivo não ramificado.

Quaresma (2014) também compara esta espécie com M. microphylla Sch.Bip. ex Baker, que se diferencia por apresentar hábito mais robusto e corola com tricomas sésseis.

10.4 Mikania conferta Gardner, London J. Bot. 4: 119. 1845.

Arbustos decumbentes, $1 \mathrm{~m}$ alt. Ramo multicostado, densamente hirsuto-tomentoso, glanduloso-pontoado. Folhas opostas; pecíolo 5-10 $\mathrm{mm}$ compr., densamente hrsuto-tomentoso; lâminas 46,3-86,3 mm compr., 23,2-44,1 $\mathrm{mm}$ larg., largolanceoladas ou ovadas, ápice agudo ou longo acuminado, base arredondada, margem inteira, face adaxial setoso-estrigosa, face abaxial densamente hirsuto-tomentosa, camptódromas. Capitulescência em tirsos; capítulos sésseis; invólucro campanulado, 3,5-4,6 mm compr., 3,1-4,4 mm larg.; bráctea subinvolucral 3,6-4,1 mm compr., 1,3-2,8 mm larg., largo-oblongas, ápice agudo, ciliado, margem inteira, face adaxial hirsuta próximo ao ápice; brácteas involucrais 4,1-4,8 mm compr., 0,9-1,2 mm larg., oblongas, ápice agudo, ciliado, margem inteira, face adaxial hirsuta próximo ao ápice. Receptáculo plano, glabro. Corola com tubo 0,9-1,4 mm compr., glabro; limbo 1,5-1,6 mm compr., glabro; lacínias 0,8-1 mm compr., ápice externamente hirsuto, margens mamilosas. Anteras com base arredondada, apêndice apical lanceolado. Ramos do estilete lineares, papilosos. Cipselas obcônicas ou cilíndricas, 1,2-2,4 mm compr., 0,1-0,3 mm diâm., glabras; carpopódio indistinto. Pápus 4,1-4,7 mm compr., cerdas às vezes com ápice truncado.

Material examinado: Minas Gerais, Santana do Riacho, PARNA Serra do Cipó, próximo ao Palácio, km 135 , 25.IV.1978, fl e fr., H.C. Lima 390 (HB, HUFU, RB); Serra do Cipó, $10-20 \mathrm{~km}$ ao nordeste de Cardeal Mota, caminho a Conceição do Mato Dentro, $19^{\circ} 20^{\prime} \mathrm{S} 43^{\circ} 35^{\prime} \mathrm{W}, 15 . \mathrm{V} .1990$, fl. r fr., M.M. Arbo et al. 4163 (MBM).

Mikania conferta pode ser encontrada em Minas Gerais e Rio de Janeiro, em Cerrado e Mata Atlântica. Na área de estudo ocorre em margens de rios. A espécie é próxima à $M$. banisteriae pelo hábito decumbente a lianescente e ramos densamente hirsutos. Entretanto $M$. conferta possui lâminas com face adaxial setoso-estrigosa, base arredondada, capitulescência em tirsos e brácteas subinvolucral largo-oblonga vs. lâminas com face adaxial estrigosa, base cordada, capitulescência em corimbos e bráctea subinvolucral lanceolada em $M$. banisteriae.

10.5 Mikania cordifolia (L. f.) Willd., Sp. PI. 3 (3): 1746. 1803.

Lianas. Ramo cilíndrico, multicostado, glanduloso-pontoado. Folhas opostas; pecíolo 4,343,3 mm compr., glanduloso-pontoado; lâminas 12,4122,8 mm compr., 2,8-47,4 mm larg., cordadas, ápice acuminado, base cordada ou sagitada, margem inteira, face adaxial incana, glanduloso-pontoada, face abaxial densamente glanduloso-pontoada, paralelódromas. Capitulescência em racemos corimbiformes; capítulos com pedúnculo 0,5-1,3 $\mathrm{mm}$ compr., glanduloso-pontoado; invólucro cilíndrico, 1,54,2 mm compr., 0,8-1,6 $\mathrm{mm}$ larg.; bráctea subinvolucral lanceolada, ápice apiculado, margem inteira; brácteas involucrais 4,4-4,7 mm compr., 1,21,3 mm larg., lanceoladas, ápice apiculado, margem inteira, glabras. Receptáculo plano, glabro. Corola com tubo 1-1,2 mm compr.; lacínias ca. 0,4 mm compr., glanduloso-pontoadas externamente. Anteras com base arredondada, apêndice apical lanceolado. Ramos do estilete lineares, papilosos. Cipselas prismáticas, 0,3-0,4 mm compr., 0,1-0,2 mm diâm., glanduloso-pontoadas; carpopódio simétrico, anelar. Pápus 0,8-1,1 mm compr.

Material examinado: Minas Gerais, Santana do Riacho, região pantanosa no pasto abaixo do Alto Palácio, 24.III.1994, bot. e fl., J.A. Lombardi 543 (BHCB).

Material adicional examinado: Minas Gerais, Uberlândia, EEP, 3.IV.1987, fl., G.M. Araújo s.n. (HUFU 1015); EEP, vereda 4, lado direito, borda, 30.IV.1999, fl., A.A.A. Barbosa 1989 (HUFU).

Mikania cordifolia ocorre em Amazonas, Bahia, Ceara, Espírito Santo, Goiás, Mato Grosso, Mato Grosso do Sul, Minas Gerais, Pará, Paraná, Pernambuco, Piauí, Rio de Janeiro, Rio Grande do Sul, Rondônia, Santa Catarina, São Paulo, Sergipe e Distrito Federal. Na área de estudo ocorre em regiões alagadas. A espécie pode ser reconhecida por apresentar lâminas foliares com ápice acuminado, venção actinódroma, brácteas com ápice apiculado e cipselas glanduloso-pontoadas.

10.6 Mikania cynanchifolia Hook. \& Arn. ex B.L.Rob.

Subarbustos escandentes, 0,8 m alt. Ramo cilíndrico, multicostado, esparso glanduloso próximo aos nós. Folhas opostas; pecíolo 2,9-27,8 mm compr., glabro; lâminas 9,5-139 mm compr., 5,6-72 mm larg., ovadas ou sagitadas, ápice agudo, base sagitada, margem inteira a ondulada ou repanda, ambas faces esparsamente glanduloso-pontoadas, paralelódromas. Capitulescência em panículas corimbiformes; capítulos 
com pedúnculo 0,6-1,3 $\mathrm{mm}$ compr., glabro; invólucro cilíndrico, 2,1-4,4 mm compr., 0,8-1,7 mm larg.; bráctea subinvolucral 1,4-2,1 mm compr., 0,4-0,6 mm larg., lanceolada, ápice agudo, margem inteira, face adaxial glanduloso-pontoada; brácteas involucrais 1,44,3 mm compr., 0,7-1,4 $\mathrm{mm}$ larg., lanceoladas a oblongo-lanceoladas, ápice cuspidado, ciliado, serrilhado, margem inteira. Receptáculo plano, glabro. Corola com tubo 1-1,3 mm compr., esparsamente glanduloso-pontoado próximo à base; limbo 0,8-1,2 mm compr., glabro; lacínias 0,6-0,8 mm compr., glanduloso-pontoada externamente. Anteras com base cordada, apêndice apical lanceolado. Ramos do estilete lineares, papilosos. Cipselas obcônicas, 1,21,5 mm compr., 0,2-0,3 mm diâm., glandulosopontoadas; carpopódio simétrico. Pápus 2,6-3,4 mm compr., alaranjado, cerdas com o ápice longamente agudo.

Material examinado: Minas Gerais, Santana do Riacho, rodovia Belo Horizonte-Conceição do Mato Dentro, ca. $9 \mathrm{~km}$ após Chapeu de Sol, 19¹7'25,5"S 4334'02,6"W, 10.III.1995, bot. e fl., V.C. Souza et al. 8188 (ESA, HUFU); Santana do Riacho, $17 \mathrm{~km}$ do córrego Chapéu de Sol, próximo ao km 121 da estrada para Conceição do Mato Dentro, 26.II.1984, bot. e fl., E.C. Dalcin 010 \& C. Farney (RB).

Mikania cynanchifolia ocorre no Mato Grosso do Sul, Minas Gerais, Rio Grande do Sul e Santa Catarina. Na área de estudo pode ser encontrada em matas de galeria. Pode ser reconhecida por apresentar seus ramos glabros, lâminas foliares com margem ondulada ou repanda e cerdas do pápus com ápice longamente agudo.

10.7 Mikania itambana Gardner, London J. Bot. 5: 481. 1846

Arbustos, 0,6-1 m alt., eretos. Ramo cilíndrico, multicostado, tomentoso. Folhas opostas cruzadas; pecíolo 0,9-2,4 $\mathrm{mm}$ compr., tomentoso; lâminas 8-26,3 mm compr., 5,9-20,6 mm larg., elípticas, ovadas ou lanceoladas, ápice mucronado, base arredondada, margem serreada ou inteira, levemente revoluta, face adaxial glabra, às vezes serícea nas nervuras, face abaxial esparsamente serícea, glanduloso-pontoada, broquidódromas. Capitulescência em panículas umbeliformes; capítulos com pedúnculo 1,1-3 $\mathrm{mm}$ compr., tomentoso; invólucro estreito-campanulado, 2,7-6,6 mm compr., 2,4-3,9 mm larg.; bráctea subinvolucral oblongolanceolada, ápice arredondado, margem inteira; brácteas involucrais 2,5-5,3 $\mathrm{mm}$ compr., 1,5-1,8 $\mathrm{mm}$ larg., oblongo-lanceoladas, ápice arredondado, margem inteira, hialina, ciliada, glabras. Receptáculo plano, glabro. Corola glabra, tubo 1,3-1,4 mm compr.; fauce alargada, 2-2,4 mm compr.; lacínias 1,1-1,2 $\mathrm{mm}$ compr. Anteras com base sagitada, apêndice apical lanceolado. Ramos do estilete lineares, mamilosos. Cipselas obcônicas, 1,1-2,4 mm compr.,
0,4-0,8 mm diâm., glabras; carpopódio simétrico, anelar. Pápus 4,6-5,4 mm compr.

Material examinado: Minas Gerais, Serra do Cipó, estrada para Conceição do Mato Dentro, próximo ao trevo para Morro do Pilar, $19^{\circ} 13^{\prime} 34^{\prime \prime S} 43^{\circ} 30^{\prime} 20^{\prime \prime W}, 1$.VII.2015, fl. e fr., F.L. Contro et al. 101 (HUFU); RPPN Brumas do Espinhaço, estrada para a sede, aproximadamente $400 \mathrm{~m}$ da porteira da sede, $19^{\circ} 03^{\prime} 53^{\prime \prime S} 43^{\circ} 42^{\prime} 25^{\prime \prime W}, 3$.VII.2015, fl. e fr., F.L. Contro et al. 154 (HUFU); Estrada para Conceição do Mato Dentro, aproximadamente $\mathrm{km} \mathrm{120,} \mathrm{trilha} \mathrm{ao} \mathrm{lado} \mathrm{direito}$ da rodovia, 19¹4'85"S 4330'69"W, 18.XII.2014, fl. e fr., F.L. Contro 34 \& D. Marques (HUFU); Estrada para Conceição do Mato Dentro, km 123, 19¹3'26"S 43³0'07"W, 30.VI.2015, fl., F.L. Contro et al. 87 (HUFU); Santa Luzia, Serra do Cipó, 7.III.1933, fl. e fr., Mello Barreto 3975 (BHCB, BHMH); Santa Luzia, Serra do Cipó, km 128, 6.VIII.1933, fl. e fr., Mello Barreto 3976 (BHCB, BHMH); Santana do Riacho, 19.V.1990, bot. e fl., A. Inacia s.n. (BHCB 18181); Santana do Riacho, cerca de 1-2 km acima Córrego Chapéu de Sol, 3.VII.1996, fl., V.C. Souza et. al. 11552 (ESA, HUFU, UEC).

Mikania itambana é endêmica de Minas Gerais, em áreas de Cerrado. Na área de estudo pode ser encontrada em campo rupestre. A espécie pode ser reconhecida por apresentar seus ramos tomentosos, lâminas com margem revoluta e venação broquidódroma e brácteas involucrais glabras. É próxima de $M$. leiolaena, mas esta apresenta ramos hirsuto-tomentosos, lâminas com margem serreada, venação camptódroma e pápus alaranjado.

\subsection{Mikania leiolaena DC., Prodr. 5: 188. 1836.}

Arbustos, até $1,5 \mathrm{~m}$ alt., eretos. Ramo cilíndrico, multicostado, hirsuto-tomentoso. Folhas opostas; pecíolo 1,1-4,5 $\mathrm{mm}$ compr., densamente hirsuto-tomentoso; lâminas 5,3-43,6 mm compr., 2,7$37 \mathrm{~mm}$ larg., ovadas, ápice mucronado ou às vezes arredondado, base arredondada, margem serreada, face adaxial esparso-estrigosa ou hirsuto-tomentosa, face abaxial densamente hirsuto-tomentosa, camptódromas. Capitulescência em panículas corimbiformes; capítulos com pedúnculo 0,4-1,7 mm compr., hirsuto-tomentoso; invólucro cilíndrico 3,3-4,5 $\mathrm{mm}$ compr., 2-3,4 mm larg.; bráctea subinvolucral lanceolada, ápice curto-mucronado, margem inteira; brácteas involucrais 2,9-3,9 mm compr., 1-1,2 mm larg., lanceoladas, ápice curto-mucronado, ciliado, margem hialina. Receptáculo plano, glabro. Corola com tubo 3,7-4,4 mm compr., glabro; lacínias 0,5 mm compr., ápice papiloso externamente. Anteras com apêndice apical ovado, base arredondada. Ramos do estilete lineares, mamilosos. Cipselas prismáticas, 1$1,1 \mathrm{~mm}$ compr., 0,4-0,5 mm diâm., glabras; carpopódio insistinto. Pápus 4,8-5,2 mm compr., alaranjado.

Material examinado: Minas Gerais, Santana do Riacho, próximo ao km 127, 16.VII.1977, fl. e fr., G. Martinelli 2619 (RB); Santana do Riacho, $14 \mathrm{~km}$ ao norte do Chapéu de Sol, 3.VII.1976, fl., G. Martinelli 862 (RB); Santana do Riacho, MG-010, 21.V.1982, fl., H.P. Bautista 614 (RB); Serra do 
Cipó, estrada de São José de Almeida-Cardeal Mota, segunda entrada para MG 020, aproximadamente $\mathrm{km} \mathrm{88,}$ 19॰22'49"S 4340'13"W, 29.VI.2015, bot. e fl., F.L. Contro et al. 60 (HUFU); Jaboticatubas, VII.1949, fl. e fr., J. Vidal s.n. (R 52224); Santana do Riacho, atual km 109, 2.VIII.1990, fl. e fr., C.M. Sakuragui \& V.C. Souza 62 (ESA, SPF); Serra do Cipó, cerca de 1-2 km do córrego Chapéu de Sol, 3.VII.1996, fl. e fr., V.C. Souza et al. 11552 (ESA, HUFU); Jaboticatubas, estrada para Conceição, km 145, 12.VII.1940, fl. e fr., M.B. Foster \& Mello Barreto 10889 (BHCB, BHMH); Santa Luzia, Serra do Cipó, 24.VI.1933, fl. e fr., Mello Barreto 3974 (BHCB, BHMH).

Mikania leiolaena é endêmica de Minas Gerais, nos domínios do Cerrado e Mata Atlântica. $\mathrm{Na}$ área de estudo ocorre em campo rupestre e campos com cascalho. É bastante similar à $M$. itambana, cujas relações foram estabelecidas anteriormente.

Pode ser reconhecida por apresentar seus ramos densamente tomentosos e com coloração levemente ferrugínea, folhas com base arredondada e tomentosas e ramos do estilete mamilosos. 1876.

10.9 Mikania lindbergii Baker, FI. Bras. 6 (2): 232.

Arbustos, 0,7 m alt., eretos. Ramo cilíndrico, multicostado, hirsuto-tomentoso. Folhas opostas; pecíolo 2,2-3,5 $\mathrm{mm}$ compr., densamente tomentoso; lâminas 8,3-30,9 mm compr., 6,5-32,8 mm larg., largo-elípticas, ovadas, ápice arredondado, obtuso ou às vezes mucronado, base cordada a arredondada, margem inteira a serreada, às vezes revoluta, face adaxial estrigosa, glanduloso-pontoada, face abaxial densamente tomentosa, glanduloso-pontoada, broquidódromas. Capitulescência em panículas de dicásio; capítulos com pedúnculo 2,5-3,7 mm compr., tomentoso; invólucro campanulado, 2,9-3,8 $\mathrm{mm}$ compr., 2,1-3,2 mm compr.; bráctea subinvolucral oblonga, ápice arredondado, margem inteira; brácteas involucrais 4,1-4,5 $\mathrm{mm}$ compr., 1,2-1,4 $\mathrm{mm}$ larg., oblongas, ápice arredondado, ciliado, margem inteira, hialina. Receptáculo plano, glabro. Corola com tubo 0,4-2,9 mm compr., glabro; lacínias 1,8-2,5 mm compr., ápice com tricomas setosos. Anteras com base sagitada, apêndice apical lanceolado. Ramos do estilete lineares, papilosos. Cipselas obcônicas, 0,52,2 mm compr., 0,4-0,7 mm diâm., glabras, carpopódio indistinto. Pápus 3,1-5,9 mm compr., cerdas com ápice espessado, alaranjadas.

Material examinado: Minas Gerais, Conceição do Mato Dentro, Pito Aceso, 19.V.1989, fl. e fr., G. Hatschbach 52915 \& V. Nicolack (MBM).

Mikania lindbergii pode ser encontrada na Bahia, Espírito Santo, Minas Gerais, Paraná, Rio de Janeiro, Santa Catarina e São Paulo, em Caatinga, Cerrado e Mata Atlântica. Na área de estudo ocorre em cerrado e campo rupestre. Barroso (1959), Nakajima (2000) e Quaresma (2014) citam a semelhança desta espécie com $M$. paranahybensis G.M.Barroso que se diferencia pela presença de folhas crassas com ápice acuminado, base arredondada e pápus decíduo (vs. folhas membranáceas ou cartáceas, ápice obtuso, base aguda e pápus persistente).

10.10 Mikania luetzelburgii Mattf., Notizbl. Bot. Gart. Berlin-Dahlem 9: 381. 1925.

Arbustos, 0,7 m alt., eretos. Ramo cilíndrico, multicostado, hirsuto-tomentoso. Folhas opostas; pecíolo 2,2-3,5 $\mathrm{mm}$ compr., densamente tomentoso; lâminas 8,3-30,9 mm compr., 6,5-32,8 mm larg., largo-elípticas, ovadas, ápice arredondado, obtuso ou às vezes mucronado, base cordada a arredondada, margem inteira a serreada, às vezes revoluta, face adaxial estrigosa, glanduloso-pontoada, face abaxial densamente tomentosa, glanduloso-pontoada, broquidódromas. Capitulescência em panículas de dicásio; capítulos com pedúnculo 2,5-3,7 mm compr., tomentoso; invólucro campanulado, 2,9-3,8 $\mathrm{mm}$ compr., 2,1-3,2 mm compr.; bráctea sbinvolucral oblonga, ápice arredondado, margem inteira; brácteas involucrais 4,1-4,5 mm compr., 1,2-1,4 mm larg., oblongas, ápice arredondado, ciliado, margem inteira, hialina. Receptáculo plano, glabro. Corola com tubo 0,4-2,9 mm compr., glabro; lacínias 1,8-2,5 mm compr., ápice com tricomas setosos. Anteras com base sagitada, apêndice apical lanceolado. Ramos do estilete lineares, papilosos. Cipselas obcônicas, 0,52,2 mm compr., 0,4-0,7 mm diâm., glabras, carpopódio indistinto. Pápus 3,1-5,9 mm compr., cerdas com ápice espessado, alaranjadas.

Material examinado: Minas Gerais, Serra do Cipó, estrada para Morro do Pilar, aproximadamente km 205, 19॰13'35"S 4328'59"W, 1.VII.2015, fl. e fr., F.L. Contro et al. 105 (HUFU); Santana do Riacho, PARNA Serra do Cipó, região de Congonhas, abaixo da Casa de Pedra, próximo ao córrego Gavião, 5.VII.1992, fl. e fr., M. Pereira \& M. Lucca 854 (BHCB); Santana do Riacho, PARNA Serra do Cipó, região de Congonhas, abaixo da Casa de Pedra, próximo ao córrego Gavião, 24.IX.1991, fr., M. Pereira et al. 827 (BHCB).

Mikania luetzelburgii ocorre na Bahia e em Minas Gerais, em Caatinga e Cerrado. Na área de estudo pode ser encontrada em campo rupestre. A espécie pode ser reconhecida por apresentar lâminas foliares largo-elípticas a ovadas com base cordada, face adaxial estrigosa e abaxial tomentosa, venação broquidódroma e lacínias com tricomas setosos.

É similar à M. leiolaena por apresentarem os ramos tomentosos, folhas ovadas e com ápice, às vezes mucronado, porém se difere da mesma por apresentar folhas com venação broquidodroma, corola com lacínias setosas externamente e ramos do estilete papilosos ( $v s$. venação camptódroma, corola com lacínias papilosas externamente e ramos do estilete mamilosos). 
10.11 Mikania malacolepis B.L.Rob., Contr. Gray Herb. 104: 40.1934.

Lianas. Ramo cilíndrico, multicostado, densamente tomentoso. Folhas opostas; pecíolo 4,1$14,2 \mathrm{~mm}$ compr., densamente tomentoso; lâminas 19,7-57,3 mm compr., 4,8-30,2 $\mathrm{mm}$ larg., lanceoladas, ápice agudo, base arredondada, margem inteira, face adaxial esparsamente escabra, face adaxial densamente tomentosa, paralelódromas. Capitulescência em panículas tirsoides; ramos opostos, capítulo com pedúnculo 1,6-2,7 mm compr., densamente tomentoso; invólucro cilíndrico, 3,4-4,2 $\mathrm{mm}$ compr., 3,2-4,7 mm larg.; bráctea subinvolucral oblonga, ápice arredondado, margem inteira, seríceas; brácteas involucrais 4,2-4,3 mm compr., 1,3-1,6 mm larg., oblongas, ápice arredondado, margem inteira, face adaxial densamente serícea. Receptáculo plano, glabro. Corola glabra, tubo ca. 3,7 mm compr.; lacínias ca. 0,6 mm compr. Anteras com base arredondada, apêndice apical lanceolado. Ramos do estilete lineares. Cipselas obcônicas, 3,1-3,6 mm compr., 0,8$0,9 \mathrm{~mm}$ diâm., glabras; carpopódio indistinto. Pápus 4,5-5,1 mm compr.

Material examinado: Minas Gerais, 1845, fl. e fr., Widgren s.n. (R 85870).

Material adicional examinado: Minas Gerais, Lima Duarte, Parque Estadual do Ibitipoca, arredores do Parque, estrada para o Distrito de Moreiras, Setor Oeste, 27.VII.2001, fl., F.S. Araújo 117 (HUFU).

Mikania malacolepis pode ser encontrada em Minas Gerais e no Distrito Federal, em Cerrado. Não há dados detalhados sobre a distribuição da espécie na área de estudo. Pode ser reconhecida por apresentar suas capitulescências em tirsos opostos e bráctea subinvolucral com face adaxial serícea.

10.12 Mikania micrantha Kunth., Nov. Gen. Sp. (folio ed.) 4: 105. 1820.

Lianas. Ramo cilíndrico, multicostado, glabrescente a seríceo. Folhas opostas; pecíolo 1,8$32,9 \mathrm{~mm}$ compr., seríceo; lâminas 7,2-55,9 mm compr., 4,7-42,2 $\mathrm{mm}$ larg., cordadas, ápice mucronado, base cordada, margem denteada ou irregular, ambas faces glanduloso-pontoadas, actinódromas. Capitulescência em panículas corimbiformes; capítulos com pedúnculo $0,5-1,7 \mathrm{~mm}$ compr., esparsamente glanduloso-pontoado; invólucro cilíndrico, 2,4-5 mm compr., 1-2 mm larg.; bráctea subinvolucral lanceolada, ápice apiculado, margem inteira; brácteas involucrais 3,8-4,8 mm compr., 0,7$1,2 \mathrm{~mm}$ larg., lanceoladas, ápice apiculado, margem inteira, hialina. Receptáculo plano, glabro. Corola glabra, tubo 1,8-2,3 mm compr.; lacínias ca. 0,5 mm compr. Anteras com base arredondada, apêndice apical lanceolado. Ramos do estilete lineares, papilosos. Cipselas prismáticas, $0,7-0,8 \mathrm{~mm}$ compr., 0,1-0,2 mm diâm. Pápus 1,9-3,3 mm compr.
Material examinado: Minas Gerais, Jaboticatubas, 5 $\mathrm{km}$ ao norte de Chapéu de Sol, I.1950, bot. e fl., s.d., col. anônimo (R 118004).

Material adicional examinado: Minas Gerais, Uberlândia, CCPIU, 12.V.2000, fl., A.A.A. Barbosa 3277 (HUFU); Uberlândia, estrada para Campo Florido, a $20 \mathrm{~km}$ do centro da cidade, 11.VI.1999, fl., G.M. Araújo 2604 (HUFU).

Mikania micrantha pode ser encontrada no Acre, Amapá, Amazonas, Bahia, Ceará, Espírito Santo, Goiás, Maranhão, Mato Grosso, Mato Grosso do Sul, Minas Gerais, Pará, Paraná, Rio de Janeiro, Rio Grande do Sul, Rondônia, Roraima, Santa Catarina, São Paulo e Distrito Federal, nos domínios da Amazônia, Caatinga, Cerrado, Mata Atlântica, Pampa, Pantanal. Segundo (Ritter et. al. 2015) são possíveis habitats de ocorrência da espécie: campo limpo, cerrado, vegetação sobre afloramentos rochosos.

Ritter \& Miotto (2005) afirmam que esta espécie é parte de um grupo complexo que envolve $M$. scandens (L.) Willd., que pode se diferenciar por sua distribuição geográfica, restrita à América do Norte. As espécies se diferenciam, principalmente, pelas brácteas involucrais que, em $M$. scandens possuem ápice acuminado e capitulescência em dicásio vs. ápice é apiculado e capitulescência em panículas corimbiformes em M. micrantha.

10.13 Mikania microcephala DC., Prodr. 5: 200. 1836.

$$
\text { Fig. 3A, B }
$$

Lianas. Ramo cilíndrico, multicostado, hirsuto, glanduloso-pontoado. Folhas opostas; pecíolo 2,4$31,4 \mathrm{~mm}$ compr., hirsuto, glanduloso-pontoado; lâminas 5,6-70,3 mm compr., 4,4-67,5 mm larg., ovais a cordiformes, ápice agudo, base cordada, margem denteada, face adaxial incana, face abaxial glanduloso-pontoada, nervuras escabra, camptódromas, nervuras proeminentes na face abaxial. Capitulescência em tirsos patentes; capítulos com pedúnculo 0,5-1,1 mm compr., densamente hirsuto, glanduloso-pontoado; invólucro estreitocampanulado, 1,7-2,1 mm compr., 1,2-2,4 mm larg.; bráctea subinvolucral 0,9-1,3 $\mathrm{mm}$ compr., $0,2-0,3 \mathrm{~mm}$ larg., linear-lanceolada, ápice arredondado ou obtuso, margem inteira, ciliada, face adaxial hirsuta; brácteas involucrais 1,7-2 mm compr., 0,6-0,8 $\mathrm{mm}$ larg., oblongas, ápice truncado, margem inteira, hialina, ciliada, face adaxial hirsuta, glanduloso-pontoada. Receptáculo plano, glabro. Corola com tubo 0,6-0,7 $\mathrm{mm}$ compr., tricomas glandulares estipitados; limbo $0,6-0,8 \mathrm{~mm}$ compr., tricomas glandulares; lacínias $0,2-0,3 \mathrm{~mm}$ compr., pilosa internamente. Anteras com base cordada, apêndice apical lanceolado. Ramos do estilete lineares, papilosos. Cipselas obcônicas, 1-1,3 $\mathrm{mm}$ compr., 0,2-0,4 mm diâm., tricomas glandulares, pilosa nas costas; carpopódio assimétrico, anelar. Pápus 1,9-2,1 mm compr. 
Material examinado: Minas Gerais, Serra do Cipó, estrada de São José de Almeida para Cardeal Mota, segunda entrada para MG 020, aproximadamente $\mathrm{km} 88,19^{\circ} 22^{\prime} 49^{\prime \prime} \mathrm{S}$ 4340'13"W, 29.VI.2015, bot. e fl., F.L. Contro et al. 59 (HUFU); Congonhas do Norte, 15-20 Km ao norte, 20.V.1989, bot., fl. e fr., G. Hatschbach 52995 \& V. Nicolack (MBM).

Mikania microcephala ocorre em Goiás, Minas Gerais, Paraná, Rio de Janiero, São Paulo e Distrito Federal, em Cerrado e Mata Atlântica. Na área de estudo foi encontrada em borda de estrada. A espécie pode ser reconhecida por apresentar seus capítulos bastante diminutos (até $2 \mathrm{~mm}$ compr.), capitulescências em tirsos patentes e tubo da corola com tricomas glandulares estipitados.

10.14 Mikania neurocaula DC., Prodr. 5: 188. 1836.

Arbustos, 0,5 m alt., eretos. Ramo cilíndrico, multicostado, densamente sericeo-tomentoso. Folhas opostas, sésseis; lâminas 12,9-77,6 mm compr., 5,8$42,8 \mathrm{~mm}$ larg., elípticas a ovadas, ápice agudo, base decorrente, margem repanda, ambas faces tomentosas, glanduloso-pontoadas, hifódromas a camptódromas. Capitulescência em panículas; capítulos com pedúnculo 1,2-3,5 mm compr., densamente seríceo-tomentoso; invólucro estreitocampanulado, 3-5,9 mm compr., 2,4-3,9 mm larg.; bráctea subinvolucral estreito-lanceolada, 3,2-5,8 mm compr., serícea, glanduloso-pontoada; brácteas involucrais 3-5,1 $\mathrm{mm}$ compr., 1,3-2,4 $\mathrm{mm}$ larg., lanceoladas, ápice agudo, margem inteira, hialina, ciliada, face adaxial serícea, glanduloso-pontoada. Receptáculo plano, glabro. Corola glandulosopontoada, tubo 1,2-1,4 mm compr.; limbo 2,8-3,2 mm compr.; lacínias até $0,7 \mathrm{~mm}$ compr. Anteras com base arredondada ou aguda, apêndice apical ovado. Ramos do estilete lineares, papilosos. Cipselas obcônicas, 1,6-2,1 mm compr., 0,5-0,7 mm diâm., costas seríceas, glanduloso-pontoadas; carpopódio ausente. Pápus 5,5-6,2 mm compr.

Material examinado: Minas Gerais, Serra do Cipó, km 113-114, 10.VII.1968, bot., fl. e fr., A.P. Duarte 10989 (BHCB); Santana do Riacho, estrada da usina, $200 \mathrm{~m}$ da MG 010, 19॰18'20"S 4336'24.3"W, 12.VII.2013, bot. e fl., $B$. Loeuille et al. 858 (SPF).

Mikania neurocaula é endêmica de Minas Gerais, em Cerrado e Mata Atlântica. Pode ser encontrada em campos rupestres. A espécie é reconhecida e facilmente distinta das demais por apresentar uma coloração levemente begeacinzentada em toda a planta e por apresentar seus ramos e lâminas foliares densamente tomentosos. É similar à $M$. rothii por apresentarem seus ramos em coloração bege, fortemente multicostados e, por vezes, folhas conduplicadas, no entanto se difere da mesma por apresentar capitulescência em panículas, cispela não estipitada e carpopódio ausente e (vs. capitulescência em cimeiras compostas, cipsela estipitada e carpopódio indistinto).

\subsection{Mikania nummularia DC., Prodr. 5: 188.} 1836.

Arbustos, 0,6 m alt., eretos. Ramo cilíndrico, multicostado, densamente velutino. Folhas opostas; pecíolo 0,8-5,1 $\mathrm{mm}$ compr., velutíneo; lâminas 3,428,5 mm compr., 2,3-26,8 mm larg., largo-elítpicas a ovadas, ápice arredondado, base arredondada a cordada, margem serreada, ambas faces densamente velutíneas, glandulso-pontoadas, paralelódromas. Capitulescência em panículas de dicásio; capítulos com pedúnculo 0,5-1,2 $\mathrm{mm}$ compr., velutíneo, glanduloso-pontoado; invólucro campanulado, 1,9-3,5 $\mathrm{mm}$ compr., 1,7-3 mm larg.; bráctea subinvolucral 1,3-1,7 mm compr., 0,4-0,6 mm larg., lanceolada, ápice agudo, face adaxial seríceo-velutínea, glanduloso-pontoadas; brácteas involucrais 2,7-3,3 $\mathrm{mm}$ compr., 1,1-1,3 mm larg., oblongo-lanceoladas, ápice arredondado ou raramente truncado, margem inteira, ciliada, hialina, face adaxial densamente seríceo-velutínea, glanduloso-pontoada. Receptáculo plano, glabro. Corola com tubo 0,5-1,1 mm compr., glanduloso-pontoado; limbo 0,8-1 $\mathrm{mm}$ compr., esparsamente glanduloso-pontoado; lacínias 0,3-0,5 $\mathrm{mm}$ compr, externamente glanduloso-pontoadas. Anteras com base arredondadas, apêndice apical triangular. Ramos do estilete lineares, mamilosos. Cipselas obcônicas, 0,4-0,8 mm compr., 0,2-0,3 mm diâm., glanduloso-pontoadas, carpopódio simétrico, anelar. Pápus 2,1-2,4 mm compr.

Material examinado: Minas Gerais, Serra do Cipó, estrada de São José de Almeida para Cardeal Mota, segunda entrada para MG 020, aproximadamente $\mathrm{km} 88,19^{\circ} 22^{\prime} 49^{\prime \prime S}$ $43^{\circ} 40^{\prime} 13^{\prime \prime W}, 29 . V I .2015$, bot. e fl., F.L. Contro et al. 57 (HUFU); Serra do Cipó, km 152, 12.VII.1940, bot. e fl., M.B. Foster \& Mello Barreto 10888 (BHCB, BHMH).

Mikania nummularia pode ser encontrada em Minas Gerais, Paraná, Rio de Janeiro e São Paulo, em Cerrado e Mata Atlântica. Na área de estudo ocorre em borda de estrada. Pode ser reconhecida por apresentar coloração parda por toda a planta, folhas largo-elípticas e velutíneas e brácteas involucrais seríceo-velutíneas.

Nakajima (2001) cita a semelhança desta espécie com $M$. parvifolia, contudo esta apresenta capitulescência em panículas umbeliformes, ramos híspido-escabros e cerdas do pápus com coloração amarela ( $v s$. capitulescência em panículas de dicásio, ramos velutíneos e cerdas do pápus alvas). 1836

10.16 Mikania oblongifolia DC., Prodr. 5: 188.

Arbustos, 1,2 m alt., eretos. Ramo cilíndrico, multicostado, glabro. Folhas opostas, sésseis; lâminas 
9,9-49,2 mm compr., 2,2-18,2 mm larg., lanceoladas a estreito-elípticas, ápice arredondado, base decorrente, margem inteira, revoluta, ambas faces glabras, esparsamente glanduloso-pontoadas, vernicosas, camptódromas. Capitulescência em tirsos; capítulos com pedúnculo 1,1-3 mm compr., às vezes esparso-hirsuto; invólucro cilíndrico a estreitocampanulado, 5,4-7,2 mm compr., 1,9-3,6 mm larg.; bráctea subinvolucral lanceolada, ápice agudo, margem serrilhada; brácteas involucrais 5,6-7,8 mm compr., 1,1-1,5 mm larg., lanceoladas, ápice agudo, margem serrilhada, glabras. Receptáculo plano, glabro. Corola glabra, tubo 2,1-2,4 mm compr.; limbo 1,7-1,9 mm compr.; lacínias 0,6-1 mm compr. Anteras com base arredondada, apêndice apical curtamente ovado. Ramos do estilete lineares, mamilosos. Cipselas obcônicas, rostradas, 1,4-2 mm compr., 0,2$0,5 \mathrm{~mm}$ diâm., hirsutas; carpopódio simétrico, anelar. Pápus 4,5-5 mm compr., cerdas alaranjadas.

Material examinado: Minas Gerais, Serra do Cipó, Palácio, III.1943, fl. e fr., G. Black s.n. (BHCB 44197).

Material adicional examinado: Minas Gerais, Uberlândia, CCPIU, 1.XII.1995, fl., E.O. Leenza 209 (HUFU); Belo Horizonte, Serra do Curral, 19.VI.1995, fl., L. Roth 1461 (HUFU).

Mikania oblongifolia ocorre em Minas Gerais, Paraná, Rio Grande do Sul, Santa Catarina e São Paulo, em Cerrado e Mata Atlântica. Pode ser reconhecida por apresentar suas lâminas foliares lanceoladas a estreito-elípticas e vernicosas, venação camptódroma e cipselas rostradas. Assemelha-se à $M$. obtusata pela forma das lâminas (lanceoladas a elípticas) e indumento das mesmas (glabro). Podem ser diferenciadas pelo ápice das folhas, que em $M$. obtusata pode ser agudo, atenuado ou obtuso (vs. arredondado em M. oblongifolia).

\subsection{Mikania obtusata DC., Prodr. 5: 192. 1836.}

Subarbusto decumbente, $1 \mathrm{~m}$ alt. Ramo cilíndrico, multicostado, glabro, vináceo. Folhas opostas; pecíolo 2,5-5,9 mm compr., glabro; lâminas 13,7-33,8 mm compr., 1,7-24,9 mm larg., elípticas, ápice agudo, atenuado ou obtuso, base aguda, margem inteira, repanda, levemente revoluta, face adaxial glabra, face abaxial glanduloso-pontoada, paralelódromas. Capitulescência em tirsos; capítulos com pedúnculo 0,6-1,4 mm compr., setoso; invólucro 1,4-3,2 mm compr., 0,8-1,9 mm larg.; bráctea subinvolucral ca. $2 \mathrm{~mm}$ compr., 0,6 mm larg., linear a linear-lanceolada, ápice arredondado a obtuso, ciliado, margem inteira; brácteas involucrais 2,9-3,4 $\mathrm{mm}$ compr., 1,1-1,5 mm larg., oblongas, oblongolanceoladas ou obovadas, ápice arredondado, ciliado, margem inteira, hialina. Receptáculo plano, glabro. Corola com tubo 1,2-1,9 mm compr., glandulosopontoado; limbo não diferenciado; lacínias ca. 0,6 mm compr., glanduloso-pontoadas externamente. Anteras com base sagitada, apêndice apical lanceolado, ápice arredondado ou agudo. Ramos do estilete lineares, mamilosos; estilopodio alargado, ca. 0,4 mm larg., evidente. Cipselas prismáticas, 0,5-1,3 mm compr., 0,2-0,6 mm diâm., tricomas glandulares; carpopódio indistinto. Pápus 2,3-2,7 mm compr., cerdas com ápice espessado.

Material examinado: Minas Gerais, Serra do Cipó, estrada para Conceição do Mato Dentro, próximo ao trevo de

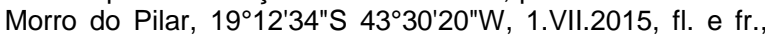
F.L. Contro et al. 100 (HUFU); Santana do Riacho, PARNA Serra do Cipó, km 117, 26.IV.1978, bot. e fl., G. Martinelli 4243 (HUFU, RB); Santana do Riacho, Lapinha, elevações imediatamente a nordeste da Lapinha, nas nascente do Córrego do Boqueirão, trilha para o alto do paredão (Serra do Breu), 1906'05"S 4340'36"W, 22.IV.2006, bot., fl. e fr., J.R. Pirani et al. 5498 (HUFU, SPF); Jaboticatubas, Palácio, III.1943., fl. e fr., G. Black c.n. (BHCB 44202).

Mikania obtusata ocorre nos estados da Bahia, Minas Gerais e São Paulo. Na área de estudo pode ser encontrada em campo rupestre. É similar à M. oblongifolia e as comparações já foram discutidas anteriormente. Almeida (2008) compara esta espécie com $M$. warmingii pela presença de margens inteiras nas folhas e corola com lacínias glandulosas. Podem ser diferenciadas pela presença de estilopódio alargado e cipsela com tricomas glandulares em $M$. obtusta e estilopódio não alargado e cipsela glanduloso-pontoada em M. warmingii.

10.18 Mikania officinalis Mart., Reise Bras. 1: 283. 1823.

Subarbustos, 0,2-0,6 m alt., eretos. Ramo cilíndrico, multicostado, glanduloso-pontoado. Folhas opostas; pecíolo 1-5,2 $\mathrm{mm}$ compr., glandulosopontoado; lâminas 2,6-17 mm compr., 1,3-15,7 mm larg., sagitadas, ápice agudo, base sagitada, margem inteira ou às vezes serreada, ambas faces glandulosopontoadas, setosa na margem, paralelódromas. Capitulescência em panículas corimbiformes; capítulos sésseis a subsésseis; invólucro cilíndrico, 2,8-5 mm compr., 1,1-2 mm larg.; bráctea subinvolucral oblongo a oblongo-lanceolada, ápice apiculado, margem inteira, glanduloso-pontoada; brácteas involucrais castanhas, 4,2-5,6 mm compr., 1-1,4 mm larg., oblongo-lanceoladas, ápice apiculado, ciliado, margem inteira, face adaxial esparsamente glandulosopontoada. Receptáculo plano, glabro. Corola com tubo 1-1,4 mm compr., glanduloso-pontoado; fauce alargada 1-1,3 mm compr., glabra; lacínias 0,7-0,8 $\mathrm{mm}$ compr., glabras. Anteras com base arredondada, apêndice apical ovado. Ramos do estilete lineares, papilosos. Cipselas obcônicas, 1,6-1,8 mm compr., 0,4-0,6 mm diâm., glanduloso-pontoadas; carpopódio simétrico, anelar. Pápus 3,1-3,5 mm compr.

Material examinado: Minas Gerais, Estrada para Conceição do Mato Dentro, aproximadamente km 120, trilha ao lado direito da rodovia, 18.XII.2014, bot. e fl., F.L. Contro 33 \& D. Marques (HUFU); PARNA Serra do Cipó, trilha do 
Cânion das Bandeirinhas, cerca de $2 \mathrm{~km}$ do Cânion, 16.XII.2014, bot., fl. e fr., F.L. Contro 12 \& D. Marques (HUFU); Jaboticatubas, Serra do Cipó, km 137, 22.III.1940, fl., Mello Barreto 10768 (BHCB, BHMH); Santa Luzia, Serra do Cipó, km 139, 6.Il.1938, fl., Mello Barreto 8862 (BHCB, $\mathrm{BHMH}$ )

Mikania officinalis pode ser encontrada em Goiás, Mato Grosso, Mato Grosso do Sul, Minas Gerais, Paraná, Rio Grande do Sul, Santa Catarina, São Paulo e Distrito Federal, em Cerrado, Mata Atântica, Pampa e Pantanal. Na área de estudo ocorre em campo rupestre.

Vários autores, como Ritter \& Miotto (2005) e Nakajima (2001), citam a semelhança desta espécie com Mikania decumbens Malme, devido à presença de folhas sagitadas/deltoides e capitulescência em panículas corimbiformes, porém $M$. officinalis é uma planta ereta e com capítulos sésseis, enquanto $M$. decumbens possui hábito decumbente e capítulos pedunculados.

10.19 Mikania parvifolia Baker in Mart., FI. Bras. 6 (2): 226. 1876.

Ervas, ca. $0.3 \mathrm{~m}$ alt., eretas. Ramo cilíndrico, multicostado, hispido-escabro, glanduloso-pontoado. Folhas opostas; pecíolo 1,3-2,4 mm compr., escabro; lâminas 3-17,9 mm compr., 3-17,3 mm larg., ovadas, ápice curto mucronado ou obtuso, base arredondada, margem crenada, revoluta, face adaxial escabra, face abaxial densamente híspida ou serícea, glandulosopontoada, paralelódromas. Capitulescência em panículas umbeliformes; capítulos com pedúnculo 0,92,2 mm compr., densamente seríceo, glandulosopontoado; invólucro estreito-campanulado, 2,1-4,6 $\mathrm{mm}$ compr., 1,3-2,5 mm larg.; bráctea subinvolucral oblonga, ápice arredondado, margem inteira; brácteas involucrais 3,5-5 $\mathrm{mm}$ compr., 1,2-1,5 $\mathrm{mm}$ larg., oblongas, ápice arredondado, margem inteira, face adaxial densamente serícea, glanduloso-pontoada. Receptáculo plano, glabro. Corola com tubo 0,8-1,1 mm compr., glanduloso-pontoado; fauce alargada 1,9 2,1 mm compr., esparsamente glanduloso-pontoada; lacínias 0,4-0,5 $\mathrm{mm}$ compr., glanduloso-pontoadas externamente. Anteras com base arredondada, apêndice apical ovado. Ramos do estilete lineares, papilosos. Cipselas obcônicas, 1,6-2 mm compr., 0,40,5 mm diâm., glanduloso-pontoada, costas ciliadas; carpopódio simétrico, anelar. Pápus 2,9-3,7 mm compr., cerdas com ápice amarelo.

Material examinado: Minas Gerais, PARNA Serra do Cipó, km 131, 24.IV.1950, bot. e fl., A.P. Duarte 2687 (HUFU, RB); Jaboticatubas, Fazenda Palácio, 14.II.1973, bot. e fl., G. Hatschbach 31551 \& L.Z. Ahumada (MBM); Santana do Riacho, Alto do Palácio, arredores da sede do IBAMA, 1.V.1993, bot. e fl., V.C. Souza \& M. Sakuragui 3320 (ESA, HUFU); Santana do Riacho, cerca de $23 \mathrm{~km}$ após os córrego Soberbo em Cardeal Mota, margem da MG 010, área a

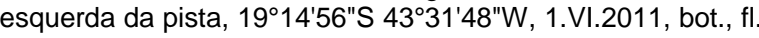
e fr., B.M. Carvalho 86 \& J.A.N. Batista (BHCB).
Mikania parvifolia pode ser encontrada em Minas Gerais, em Cerrado e Mata Atlântica. Na área de estudo ocorre em campo rupestre. É uma espécie que pode ser reconhecida por apresentar hábito herbáceo, folhas pequenas (até 1,7 cm), ovadas, escabras e paralelódromas. Almeida (2008) e Nakajima (2000) comparam esta espécie com $M$. nummularia, que se diferencia por apresentar capitulescência em panículas de dicásio ( $v s$. panículas umbeliformes).

10.20 Mikania phaeoclados Mart., Fl. Bras. 6 (2): 156. 1876 .

Lianas. Ramo cilíndrico, multicostado, ferrugíneo, hirsuto. Folhas opostas; pecíolo 1,9-9,3 mm compr., densamente hirsuto; lâminas 11,1-48,8 mm compr., 5,5-33,4 mm larg., ovadas a elípticas, ápice agudo, base cordada ou arredondada, margem serreada, face adaxial esparsamente estrigosa, face abaxial densamente hirsuto-tomentosa, paralelódromas. Capitulescência em panículas umbeliformes; capítulos com pedúnculo 1,1-3,5 mm compr., hirsuto; invólucro cilíndrico, 3,9-5,2 mm compr., 1,4-3,7 mm larg.; bráctea subinvolucral 1,6-2,6 mm compr., 0,6-0,9 mm larg., oblongo-lanceolada, ápice obtuso a arredondado, ciliado, margem inteira, ciliada; brácteas involucrais 4,5-4,8 mm compr., 0,9-1,2 mm larg., oblongas, ápice arredondado, ciliado, margem inteira, hialina. Receptáculo plano, glabro. Corola com tubo estreito, 1,2-1,5 mm compr., glabro; fauce alargada, 1,3-1,6 mm compr., glabra; lacínias $1 \mathrm{~mm}$ compr., ápice hirsuto na face interna. Anteras com base arredondada, apêndice apical ovado a lanceolado. Ramos do estilete lineares, mamilosos. Cipselas cilíndricas, 1,9-2,5 mm compr., 0,3-0,4 mm diâm., glabras; carpopódio simétrico, anelar. Pápus 4,6-5,2 mm compr.

Material examinado: Minas Gerais, Santana do Riacho, RPPN Brumas do Espinhaço, 28.XI.2012, fl., C.A Ferreira Junior et al. 747 (BHZB, HUFU); Capela São José,

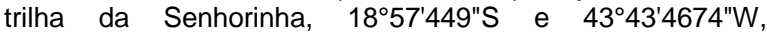
25.XI.2009, bot. e fl., D.C. Zappi et al. 2491 (RB); Serra do Cipó, antigo km 34, 14.Il.1963, fl. e fr., A.P. Duarte 7616 (HUFU, RB); Santana do Riacho, estrada Belo HorizonteC.M.Dentro, ca. $2 \mathrm{~km}$ após bifurcação para Morro do Pilar, 27.II.2002, fl., V.C. Souza et. al. 28536 (ESA).

Mikania phaeoclados pode ser encontrada na Bahia, Espírito Santo e Minas Gerais, em Cerrado e Mata Atlântica. Na área de estudo ocorre em campos rupestres. Pode ser reconhecida, entre as demais lianas, pela presença de lâminas ovadas com base cordada, face adaxial estrigosa e abaxial tomentosa, venação paralelódroma e lacínias com ápice hirsuto na face interna.

10.21 Mikania premnifolia Gardner, London J. Bot. 5: 480. 1846.

Subarbustos a arbustos, 0,5-0,7 $\mathrm{m}$ alt., eretos. Ramo multicostado, multicostado, densamente 
seríceo-tomentoso. Folhas opostas cruzadas; pecíolo 1,7-3,8 mm compr., seríceo; lâminas 6,1-33,3 mm compr., 3-25,6 mm larg., ovadas ou elípticas, ápice mucronado, base arredondada ou atenuada, margem denteada ou serreada, dentes pronunciados, face adaxial glabra, face abaxial tomentosa, glandulosopontoada, camptódromas. Capitulescência em panículas corimbiformes; capítulos sésseis; invólucro estreito-campanulado, 1,8-3,7 mm compr., 2-2,4 mm larg.; bráctea subinvolucral 1,6-3,1 mm compr., 0,30,6 mm larg., oblongo-linear, ápice obtuso ou atenuado, margem ciliada na metade superior; brácteas involucrais 1,7-3,7 mm compr., 0,9-1,5 mm larg., oblongas, ápice arredondado, obtuso ou emarginado, densamente ciliado, margem inteira, às vezes hialina, ciliada, face adaxial vernicosa. Receptáculo plano, glabro. Corola com tubo 1,3-2 mm compr., glabro; limbo 1,5-1,8 mm compr., glabro; lacínias 1-1,6 mm compr., ápice com tricomas na face adaxial. Anteras com base arredondada ou levemente cordada, apêndice apical lanceolado. Ramos do estilete lineares, papilosos, ápice espessado. Cipselas prismáticas ou rostradas, 1,3-2,5 mm compr., 0,3-0,7 mm diâm., glabras; carpopódio simétrico, anelar. Pápus 4,9-5,5 mm compr., cerdas espessadas no ápice.

Material examinado: Minas Gerais, Serra do Cipó, estrada para Conceição do Mato Dentro, Alto do Palacio, 19॰15'79"S 4332'20"W, 29.VI.2015, fl., F.L. Contro et al. 72 (HUFU); Estrada para Conceição do Mato Dentro, Alto do Palácio, 19¹5'79"S 4332'20"W, 29.VI.2015, bot. e fl., F.L. Contro et al. 73 (HUFU); Estrada para Conceição do Mato Dentro, 19॰13'26"S 4330'07"W, 30.VI.2015, fl., F.L. Contro et al. 86 (HUFU); Santana do Riacho, bifurcação para Morro do Pilar, 9.X.1987, fl. e fr., V. Abbud et al. CFSC 10763 (SPF); Santana do Riacho, rodovia Belo Horizonte - Conceição do Mato Dentro, Alto do Palácio, elevação próxima à estatua do Velho Juca, $19^{\circ} 15^{\prime}$ S $43^{\circ} 32^{\prime}$ W, 12.VII.2009, fl. e fr., J.R. Pirani et al. 6014 (HUFU, SPF); Serra do Cipó, km 116, 19.VI.1963, fl. e fr., A.P. Duarte 8091 (MBM, RB); Serra do Cipó, km 128, Palácio, 6.VIII.1933, fl., M. Barreto 3976 (R); Jaboticatubas, VII.1949, fl., J. Vidal s.n. (R 152545); Jaboticatubas, VII.1949, fl., J. Vidal s.n. (R 152541); Rodovia Belo HorizonteConceição do Mato Dentro, próximo à bifurcação para Morro do Pilar, 5.VII.1996, fl., V.C. Souza et al. 11727 (ESA, HUFU).

Mikania premnifolia ocorre em Minas Gerais, em Cerrado. Na área de estudo ocorre em campos rupestres, brejos e matas montanas. Pode ser reconhecida por apresentar suas folhas dispostas com filotaxia oposta e cruzada, ovadas ou elípticas e margem com dentes pronunciados. 1836.

10.22 Mikania psilostachya DC., Prodr. 5: 190.

Ervas volúveis. Ramo cilíndrico, multicostado, esparsamente glanduloso-pontoado, glabrescente. Folhas opostas; pecíolo 2,4-14,3 mm compr., glabro; lâminas 19,3-59,8 mm compr., 8,2-16,4 mm larg., lanceoladas, ápice longo-agudo, às vezes acuminado, base aguda, margem inteira, ambas faces glandulosopontoadas, broquidódromas. Capitulescência em ramos espiciformes; capítulos sésseis; invólucro cilíndrico a estreito-campanulado, 3,1-5,2 mm compr., 1,9-2,2 mm larg.; bráctea subinvolucral 1,3-2 mm compr., $\quad 0,3-0,4 \mathrm{~mm}$ larg., lineares a linearlanceoladas, ápice agudo a acuminado, margem inteira, às vezes ciliada, face adaxial glabrescente ou serícea; brácteas involucrais 2,7-5,1 mm compr., 0,1$0,8 \mathrm{~mm}$ larg., oblongas, ápice agudo, às vezes truncado, ciliado, margem inteira, glabra. Receptáculo plano, glabro. Corola glabra, tubo 1,3-1,6 mm compr.; limbo 0,6-0,7 mm compr.; lacínias 0,6-0,8 mm compr. Anteras com base sagitada, apêndice apical ovado, ápice emarginado. Ramos do estilete lineares, papilosos. Cipselas obcônicas, 3-4 mm compr., 0,40,7 mm diâm., glabras, incanas próximo ao ápice; carpopódio simétrico, anelar. Pápus 2,6-3 mm compr., cerdas com ápice espessado.

Material examinado: Minas Gerais, Santana do Riacho, rodovia MG 010, cerca de $1,5 \mathrm{~km}$ antes da bifurcação entre Morro do Pilar e Conceição do Mato Dentro, 24.VI.1994, fl. e fr., M.T.V.A. Campos CFSC 13740 (HUFU, SPF).

Material adicional examinado: Minas Gerais, Uberlândia, Fazenda São José, 17.XII.2010, fl., B.C. Vargas 290 (HUFU).

Mikania psilostachya ocorre no Acre, Amapá, Amazonas, Bahia, Ceará, Goiás, Maranhão, Mato Grosso, Mato Grosso do Sul, Minas Gerais, Pará, Rio de Janeiro, Rondônia, Roraima, São Paulo, Tocantins e Distrito Federal, nos domínios da Amazônia, Caatinga, Cerrado e Mata Atlântica. Na área de estudo pode ser encontrada em borda de mata. A espécie é facilmente distinta das demais do gênero por apresentar sua capitulescência com ramos espiciformes e anteras com ápice emarginado.

10.23 Mikania purpurascens (Baker) R.M.King \& H.Rob., Phytologia 47: 126. 1980.

Arbustos eretos, até 1,2 m alt. Ramo cilíndrico, multicostado, hirsuto. Folhas opostas; discolores, pecíolo 1,3-3,9 mm compr., hirsuto; lâminas 4,8-30,1 mm compr., 3,8-20 mm larg., ovadas, ápice curto mucronado, base arredondada ou cordada, margem inteira ou às vezes ondulada, ambas faces tomentosas, glanduloso-pontoadas, actinódromas basais. Capitulescência em panículas corimbiformes; capítulos com pedúnculo 0,8-3,2 mm compr., hirsuto; invólucro cilíndrico 4,3-6,3 mm compr.; bráctea subinvolucral lanceolada, ápice agudo, margem inteira, hirsuta; brácteas involucrais 5,6-7,1 mm compr., 1,7-2,2 mm larg., lanceoladas, ápice agudo, margem inteira, ciliada, face adaxial hirsuta, avermelhadas. Receptáculo plano, glabro. Corola com tubo 2,8-3,4 mm compr., glabro a esparsamente hirsuto próximo à base; lacínias 1,1-1,5 $\mathrm{mm}$ compr., glabras. Anteras com base arredondada ou curtamente cordada ou sagitada, apêndice apical 
ovado. Ramos do estilete lineares, tricomas coletores. Cipselas obcônicas, 2,3-4,2 mm compr., 0,7-1,4 mm diâm., hirsutas; carpopódio assimétrico, anelar. Pápus 3,9-5,5 mm compr., cerdas com coloração ferrugínea.

Material examinado: Minas Gerais, Santana do Riacho, 10.V.1974, fl. e fr., G. Martinelli 255 (RB); Serra do Cipó, 17.Il.1972, bot. e fl., W.R. Anderson et al. s.n. (RB 160465); Santana do Riacho, Trilha do João Carrinho, 25.Il.2009, fl., D.C. Zappi 1575 (RB, SPF); PARNA Serra do Cipó, 31.I.1965, fl., A.P. Duarte 9045 (HUFU, RB); Jaboticatubas, 17.I.1972, bot. e fl., G. Hatschbach et al. 28750 (MBM); Jaboticatubas, 5.VIII.1972, bot. e fl., G. Hatschbach et al. 29913 (MBM); Serra do Cipó, 5.VIII.1958, fl. e fr., Heringer \& Castellanos 22123 (R); Santana do Riacho, PARNA Serra do Cipó, região do Congonhas, abaixo da Casa de Pedra, próximo ao córrego Gavião, 14.III.1993, fl., M. Lucca 20 (BHCB)

Mikania purpurascens é endêmica de Minas Gerais. Na área de estudo pode ser encontrada em campos rupestres. Facilmente reconhecida entre as demais da espécie pela presença de pápus com coloração fortemente ferrugínea, folhas discolores e pecioladas.

10.24 Mikania ramosissima Gardner, London J. Bot. 5: 483. 1846.

Ervas volúveis. Ramo cilíndrico, multicostado, glabro, às vezes glanduloso-pontoado. Folhas opostas; pecíolo 2,2-12,1 mm compr., glabro; lâminas 4,4-61,2 mm compr., 1,9-19,5 mm larg., discolores, lanceoladas ou oblongo-lanceoladas, ápice obtuso, base aguda, margem inteira, revoluta, face adaxial glandulosopontoada, castanha, face abaxial glandulosopontoada, bege a acinzentada, peninérveas a camptódromas. Capitulescência em racemos ou espigas; capítulos com pedúnculo 1,2-3,4 mm compr., glabro, às vezes seríceo; invólucro cilíndrico, 2,3-4,7 $\mathrm{mm}$ compr., 1,3-2,2 mm larg.; bráctea subinvolucral 1,1-1,8 mm compr., oblonga ou oblongo-lanceolada, ápice arredondado ou obtuso, às vezes ciliado, margem inteira, face adaxial glabrescente; brácteas involucrais 1,4-4 mm compr., 0,4-1,3 mm larg., oblongas, ápice arredondado ou obtuso, margem inteira, face adaxial esparso-glanduloso-pontoada. Receptáculo plano, glabro. Corola com tubo 0,6-0,9 $\mathrm{mm}$ compr., glabro; limbo 0,5-0,8 mm compr., glabro; lacínias 0,6-0,9 mm compr., papilosas internamente. Anteras com base sagitada, apêndice apical oblongo, ápice obtuso, raramente agudo. Ramos do estilete lineares, papilosos. Cipselas prismáticas, 1,8-2,5 mm compr., 0,5-0,6 mm diâm, glabras; carpopódio assimétrico, anelar. Pápus 1,8-2,2 mm compr., cerdas com ápice espessado.

Material examinado: Minas Gerais, Congonhas do Norte, Serra Talhada, $9 \mathrm{~km}$ ao Sul de Congonhas do Norte, estrada para Conceição do Mato Dentro, 1856'14.8"S $43^{\circ} 41^{\prime} 06.1^{\prime \prime W}, 20.1 .2007$, J.R. Pirani et al. 5623 (SPF); Santa Luzia, Serra do Cipó, km 133, 25.XI.1938, fl. e fr., Mello Barreto 8540 (BHCB, BHMH); Santana do Riacho, RPPN
Brumas do Espinhaço e Ermo dos Gerais, 28.XI.2012, fl. e fr., C.A. Ferrerira Junior et al. 743 (BHZB, SPF).

Mikania ramosissima pode ser encontrada na Bahia, Goiás, Minas Gerais e Distrito Federal, em Cerrado e Caatinga. Na área de estudo ocorre em campos rupestres, matas ciliares e capão. Quaresma (2014) e Nakajima (2001) citam a semelhança desta com M. ligustrifolia DC., tanto pelas folhas lanceoladas quanto pelo tipo de Capitulescência, porém $M$. ramosissima apresenta-se quase toda glabra, lâminas foliares com ápice obtuso e brácteas involucrais lanceoladas vs planta com tricomas glandulares, lâminas com ápice acuminado e brácteas involucrais oblongas.

Espécie bastante próxima, também, à $M$. psilostachya pela capitulescência em espigas ou racemos, contudo esta apresenta suas folhas com ápice acuminado, lacínias glabras e bráctea subinvolucral linear a linear-lanceolada (vs. folhas com ápice obtuso, lacínias papilosas e bráctea subinvolucral oblonga).

10.25 Mikania reticulata Gardner, London J. Bot. 5: 480.1846 .

Arbustos, até $1 \mathrm{~m}$ alt., eretos. Ramo cilíndrico, multicostado, glabro. Folhas opostas cruzadas; pecíolo 1,8-3,7 mm compr., glabro; lâminas 4,6-32,2 mm compr., 4-22,2 mm larg., largo-elípticas, ápice mucronado ou às vezes arredondado, base aguda, margem inteira, ambas faces glabras, paralelódromas e reticuladas. Capitulescência em panículas corimbiformes; capítulos com pedúnculo 1,3-3,5 mm compr., glabro; invólucro campanulado $6,2-7 \mathrm{~mm}$ compr., 3,2-5 $\mathrm{mm}$ larg.; bráctea subinvolucral oblongo-lanceolada, ápice arredondado, margem inteira, glabra; brácteas involucrais 6,1-7,8 mm compr., 2,3-2,8 mm larg., oblongo-lanceoladas a obovadas, ápice arredondado, ciliado, margem inteira, glabra. Receptáculo plano, glabro. Corola glabra, tubo 3,7-5 mm compr.; fauce alargada; lacínias 1,7 mm compr. Anteras com base sagitada, apêndice apical lanceolado. Ramos do estilete lineares, papilosos. Cipselas obcônicas, 1,2-3,2 mm compr., 0,7-1,2 mm diâm., glabras; carpopódio simétrico, anelar. Pápus 5,4-8 mm compr., alvo.

Material examinado: Minas Gerais, Santana do Pirapama, Trilha da Senhorinha, primeiro platô, 9.III.2009, fl e fr., D.C. Zappi 1920 (RB); 19.Il.2007, fl. e fr., V.C. Souza et al. 32796 (RB); Serra do Cipó, km 128 - Palácio, 6.III.1933, fl., Mello Barreto 3976 (R); RPPN Brumas do Espinhaço, estrada para a sede, aproximadamente $400 \mathrm{~m}$ da porteira da sede,

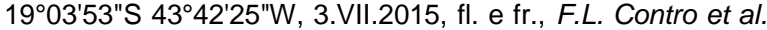
152 (HUFU); RPPN Brumas do Espinhaço, estrada para a sede, aproximadamente $400 \mathrm{~m}$ da porteira da sede, 1903'53"S 4342'25"W, 3.VII.2015, fl. e fr., F.L. Contro et al. 162 (HUFU); Santana do Pirapama, distrito de São José da Cachoeira, trilha da Senhorinha, $18.9422^{\circ} \mathrm{S} 43.7498^{\circ} \mathrm{W}$, 19.II.2007, fl. e fr., V.C. Souza et al. 32796 (BHCB, ESA).

Mikania reticulata distribui-se pelos estados da Bahia e Minas Gerais, na Caatinga e Cerrado. Na 
área de estudo pode ser encontrada em campos rupestres. Facilmente reconhecida por apresentar venação fortemente reticulada, ramos e lâminas foliares glabros. Quaresma (2014) cita proximidade com M. arrojadoi Mattf. que se diferencia por apresentar tubo e limbo da corola com mesmo tamanho e brácteas involucrais pilosas ( $v s$. tubo da corola maior que o limbo e brácteas involucrais glabras).

10.26 Mikania rothii G.M.Barroso, Arch. Jard. Bot. Rio de Janeiro 16: 217. 1959.

Subarbustos, ca. $1 \mathrm{~m}$ alt., eretos. Ramo cilíndrico, multicostado, densamente hirsutotomentoso, glanduloso-pontoado. Folhas opostas; pecíolo 3,4-11,2 $\mathrm{mm}$ compr., densamente hirsutotomentoso, glanduloso-pontoado; lâminas 8-46,8 mm compr., 3,3-16 mm larg., conduplicadas, estreitoelípticas a lanceoladas, ápice arredondado, base aguda ou atenuada, margem repanda, ambas faces puberulentas a tomentosas, glanduloso-pontoadas, paralelódromas. Capitulescência em cimeiras compostas; capítulos com pedúnculo 1,3-3,3 mm compr., densamente hirsuto, glanduloso-pontoado; invólucro campanulado. 3,5-4,8 mm compr., 2-4 mm larg.; bráctea subinvolucral 2,7-4 mm compr., 0,7-1,2 $\mathrm{mm}$ larg., linear-lanceoladas, ápice arredondado, margem inteira, face adaxial hirsuta, glandulosopontoadas; brácteas involucrais $3,5-4,5 \mathrm{~mm}$ compr., 1,4-1,6 mm larg., oblongas, ápice arredondado, margem inteira, ciliada próximo ao ápice, face adaxial hirsuto, glanduloso-pontoada. Receptáculo plano, glabro. Corola com tubo 1,2-1,6 mm compr., glanduloso-pontoado; limbo 1-2,8 $\mathrm{mm}$ compr., esparsamente glanduloso-pontoado; lacínias 0,5-1,2 $\mathrm{mm}$ compr., externamente glanduloso-pontoadas. Anteras com base sagitada, apêndice apical ovado. Reamos do estilete lineares, mamilosos, ápice obtuso. Cipselas obcônicas, às vezes estipitadas, 0,4-2,9 mm compr., 0,3-0,7 mm diâm., costas ciliadas, glandulosopontoadas; carpopódio indistinto. Pápus 2,2-5,4 mm compr., cerdas com ápice espessado.

Material examinado: Minas Gerais, Serra do Cipó, estrada para Conceição do Mato Dentro, 19²2'49"S 43॰40'13"W, 29.VI.2015, bot. e fl., F.L. Contro et al. 65 (HUFU); Serra do Cipó, estrada para Conceição do Mato Dentro, entrada para Serra Morena, aproximadamente $1 \mathrm{~km}$ do Chapéu de Sol, 30.VI.2015, bot. e fl., F.L. Contro et al. 76 (HUFU); Estrada de Lapinha da Serra-RPPN Brumas do Espinhaço, 1903'59"S 4342'24"W, 2.VII.2015, bot. e fl., F.L. Contro et al. 135 (HUFU); Santana do Riacho, rodovia Belo Horizonte-Conceição do Mato Dentro, km 106, $19^{\circ} 17^{\prime} \mathrm{N}$ 4336'W, VII.1990, fl., G.M. Faria \& M. Mazucato s.n. (SPF 86528); Jaboticatubas, 17.I.1972, fl. e fr., G. Hatschbach et al. 28718 (MBM); Jaboticatubas, 6.VIII.1972, bot., fl. e fr., G. Hatschbach 29976 (MBM); Jaboticatubas, VII.1949, bot. e fl., J. Vidal s.n. (R 152542).

Mikania rothii é endêmica de Minas Gerais e ocorre em áreas de Cerrado e Mata Atlântica. A espécie é reconhecida por apresentar suas folhas tomentosas e conduplicadas, tanto em habitat quanto herborizada, o que torna fácil sua distinção.

10.27 Mikania sessilifolia DC., Prodr. 5: 188. 1836.

Arbustos, 1,2-2 m alt., eretos. Ramo cilíndrico, multicostado, estrigoso. Folhas opostas, decussadas, sésseis; lâminas 0,4-3,2 cm compr., 0,2$2,9 \mathrm{~cm}$ larg., ovadas a cordadas, ápice atenuado ou agudo, margem crenada, revoluta, base cordada a truncada, face adaxial estrigosa, glanduloso-pontoada, face abaxial estrigosa ou escabra, glandulosopontoada, camptódromas. Capitulescência em panículas; capítulos com pedúnculo 0,6-2,1 $\mathrm{mm}$ compr., densamente estrigoso, glanduloso-pontoado; invólucro cilíndrico, 2,3-4,3 mm compr., 2-3,2 mm larg.; bráctea subinvolucral lanceolada, ápice obtuso, margem inteira, estrigosa; brácteas involucrais 3,2-3,8 $\mathrm{mm}$ compr., 0,9-1,3 mm larg., oblongo-lanceoladas, ápice agudo ou obtuso, fimbriado, margem inteira, face adaxial estrigosa, glanduloso-pontoada. Corola com tubo 1,8 mm compr., esparsamente glandulosopontoado; lobos 0,6 $\mathrm{mm}$ compr., face interna papilosa no terço superior, glanduloso-pontoado externamente. Anteras com apêndice apical ovado, base curtamente sagitada. Ramos do estilete lineares, ápice espessado, papilosos. Cipselas prismáticas a obcônicas, 1,3-1,9 mm compr., 0,4-0,5 mm diâm., esparsamente glanduloso-pontoadas entre as costas; carpopódio assimétrico, anelar. Pápus 2-2,5 mm compr.

Material examinado: Minas Gerais, Serra do Cipó, 28.IV.1973, bot. e fl., col.anônimo (RB 535812); Santana do Riacho, MG 010, $19^{\circ} 20^{\prime} S 43^{\circ} 37^{\prime}, 21$.V.1982, fl. e fr., E.F. Almeida 224 (RB); Serra do Cipó, Vale da Mãe D'Água, 1.V.1993, bot. e fl., V.C. Souza 3391 \& C.M. Sakuragui (ESA, HUFU); Santana do Riacho, 18.IV.1992, fl. e fr., M. Pereira 865 \& M. Lucca (MBM); Jaboticatubas, 5.VIII.1972, fl. e fr., G. Hatschbach 29914 (MBM); Serra do Cipó, Chapéu de Sol, 12.V.1990, fl. e fr., C.C. Dias s.n. (BHCB 18178); Santana do Pirapama, trilha da Senhorinha, primeiro platô 18 ${ }^{\circ} 55^{\prime} 22$ "S 4344'37"W, 9.III.2009, bot. e fl., D.C. Zappi et al. 1962 (RB, SPF).

Mikania sessilifolia ocorre na Bahia, Mato Grosso, Minas Gerais, Paraná, Rio Grande do Sul, Santa Catarina, São Paulo e Distrito Federal. Pode ser encontrada em campo rupestre. Uma das poucas espécies encontradas na área de estudo que possuem folhas sésseis com face adaxial estrigosa.

10.28 Mikania warmingii Sch.Bip. ex Baker in Mart., FI. Bras. 6 (2): 242. 1876.

Arbustos, 0,6 m alt., eretos. Ramo cilíndrico, multicostado, glabro, setoso próximo à capitulescência. Folhas opostas; pecíolo 2-10 mm, glabro; lâminas $0,6-4,4 \mathrm{~cm}$ compr., $0,3-3,1 \mathrm{~cm}$ larg., largo-elípticas ou ovadas, ápice obtuso, base aguda 
ou atenuada, margem serreada, face adaxial glabra, face abaxial glanduloso-pontoada, paralelódromas. Capitulescência em tirsos; capítulos com pedúnculo 12,4 mm, setoso; invólucro estreito-campanulado 1,53,1 $\mathrm{mm}$ compr, 1,4-2,6 $\mathrm{mm}$ larg.; bráctea subinvolucral 1,8-2,5 mm compr., 0,4-0,7 mm larg., oblongo-lanceolada, ápice obtuso ou arredondado, margem inteira, esparso-ciliada; brácteas involucrais 2,5-1,8 $\mathrm{mm}$ compr., 0,4-0,6 $\mathrm{mm}$ larg., oblongas, ápice obtuso, ciliado, margem inteira, glandulosopontoada externamente. Receptáculo plano, glabro. Corola com tubo 0,4-0,7 mm compr., glandulosopontoado; limbo 0,7-1 mm compr., glabro; lacínias ca. $\quad 0,3 \quad \mathrm{~mm}$ compr., glanduloso-pontoada externamente. Anteras com base curto-sagitada, apêndice apical ovado, ápice obtuso. Ramos do estilete lineares, mamilosos. Cipselas prismáticas, 0,4-0,7 mm compr., 0,2-0,4 mm diâm., glandulosopontoadas próximo ao ápice; carpopódio simétrico ou indistinto. Pápus 1,5-1,8 mm compr., cerdas com ápice espessado, às vezes alaranjado.

Material examinado: Minas Gerais, Santana do Riacho, PARNA Serra do Cipó, região do Congonhas, abaixo da Casa de Pedra, próximo ao córrego Gavião, 10.IV.1993, bot. e fl., M. Lucca 23 (BHCB).

Material adicional examinado: Minas Gerais, São Roque de Minas, Parque Nacional da Serra da Canastra, Guarita de Sacramento, 14.VII.1995, fl., J.N. Nakajima 1132a (HUFU).

Mikania warmingii pode ser encontrada em Minas Gerais, em Cerrado e Mata Atlântica. Na área de estudo ocorre em campos rupestres. Nakajima (2000) e Almeida (2008) citam a semelhança desta espécie com $M$. obtusata, porém pode ser reconhecida por apresentar corola com limbo glabro, cipsela glanduloso-pontoada e estilopódio não alargado vs. tubo e limbo da corola glanduloso-pontoado, cipsela com tricomas glandulares e estilopódio alargado em M. obtusata.

\section{Praxelis Cass., Dict. Sci. Nat. (ed. 2) 43: 261. 1826.}

Ervas ou subarbustos, eretos ou decumbentes. Ramos multicostados, glabros a pubescentes. Folhas opostas ou alternas, sésseis ou pecioladas; lâmina ovada, elíptica a linear, margem inteira a denteada, glanduloso-pontoada ou hirsutas, hifódromas a camptódromas. Capitulescência terminal ou em panículas corimbosas; capítulos subsésseis a pedunculados; invólucro cilíndrico a estreitocampanulado, 3-7-seriado; brácteas involucrais caducas. Receptáculo cônico, epaleáceo. Capítulos com 20-50 flores; corola branca a azulada, glabra, lacínias ovadas, glanduloso-pontoadas ou papilosas externamente. Anteras com colar cilíndrico, apêndice apical mais longo do que largo. Ramos do estilete lineares, papilosos, base não alargada, glabra. Cipsela obcompressas, tricomas dispersos; carpopódio distinto, assimétrico. Pápus cerdoso, barbelado, 1seriado.

Existem 24 espécies para 0 gênero distribuídas pelo Brasil, Paraguai, Argentina e Bolivia (King \& Robinson, 1987). Para o Brasil são aceitas 13 espécies, das quais 6 são endêmicas, distribuídas por todo o território nacional, ocorrendo desde a Amazônia ao Pantanal (Oliveira, 2015).

King \& Robinson (1987) diferenciam o gênero por três características bastante marcantes: pápus com muitas cerdas, invólucro com brácteas caducas e receptáculo cônico. No entanto, o gênero apresenta algumas espécies muito semelhantes à Chromolaena, e suas relações ainda não estão muito bem definidas. $\mathrm{Na}$ área de estudo foram encontradas quatro espécies: $P$. basifolia, $P$. capillaris, $P$. clematidea e $P$. kleinioides.

\section{Chave para as espécies de Praxelis}

1. Folhas concentradas na base dos ramos ..11.1 $P$. basifolia 1'. Folhas distribuídas ao longo de todo o ramo.

2. Ervas; folhas verticiladas ...................11.2 P. capillaris

2'. Subarbustos; folhas opostas.

3. Folhas pecioladas, camptódromas ou craspedódromas .........................11.3 P. clematidea

3'. Folhas sésseis, acródromas basais 11.4 P. kleinioides

11.1 Praxelis basifolia (Malme) R.M.King \& $\mathrm{H}$. Rob., Phytologia 20: 194. 1970.

Ervas, 0,2-0,3 m alt. Ramos cilíndricos, multicostados, hirsutos. Folhas opostas; concentradas na base dos ramos, sésseis; lâminas $0,6-3,1 \mathrm{~cm}$ compr., 0,1-0,5 cm larg., estreito-lanceoladas, ápice agudo, base atenuada, margem denteada, dentes pouco pronunciados, ambas faces setoso-hirsutas, glanduloso-pontoadas, hifódromas ou paralelódromas. Capitulescência terminal; solitária; invólucro campanulado, 7,9-8,3 mm compr., 5,6-6,6 mm larg., 4-5-seriado; brácteas externas 3-3,4 mm compr., 1$1,1 \mathrm{~mm}$ larg., oblongo-lanceoladas, lanceoladas ou raramente ovadas, ápice apiculado, arroxeado, margem inteira, glabras, as medianas 5,5-7,1 mm compr., 1,1-11,5 mm larg., oblongas, ápice apiculado, arroxeado, margem inteira, glabras, as internas 7,5-8 $\mathrm{mm}$ compr., 1,3-1,6 mm larg., ápice apiculado, arroxeado, margem inteira, glabras. Receptáculo cônico, glabro. Capítulo com até 60 flores; corola com tubo 2,5-3,5mm compr., glabro; lacínias 0,6-0,8 mm compr., papilosas internamente. Anteras com base sagitada, apêndice ovado ou oblongo, ápice obtuso. Ramos do estilete lineares, ápice espessado, tricomas glandulares. Cipselas obcônicas, 1-2,4 mm compr., 0,4-0,7 mm diâm., glabras; carpopódio assimétrico ou inconspícuo. Pápus 4-4,6 mm compr. 
Material examinado: Minas Gerais, PARNA Serra do Cipó, trilha para cachoeiras e capão, 15.XII.2014, fl., F.L. Contro \& D. Marques 06 (HUFU).

Material adicional examinado: Minas Gerais, Uberlândia, EEP, 11.IX.1998, fl., A.A.A. Barbosa 1227 (HUFU); Uberlândia, estrada para Campo Florido, vereda 2, 4.XII.1998, fl., M.T.O. Lemos s.n. (HUFU 18388).

Praxelis basifolia pode ser encontrada no Mato Grosso, Mato Grosso do Sul, Minas Gerais e São Paulo, em Cerrado. Na área de estudo pode ser encontrada em campo úmido. A espécie é facilmente reconhecida entre as demais, do gênero e da área de estudo, por apresentar suas folhas concentradas na base.

11.2 Praxelis capillaris (DC.) Sch.Bip., Jahresber. Pollichia 22-24: 254. 1866.

Erva, 0,4 m alt. Ramos cilíndricos, glabros. Folhas verticiladas, sésseis; lâminas $0,2-2,2 \mathrm{~cm}$ compr., 0,02-0,05 cm larg., estreito-lineares, ápice agudo, base amplexicaule, margem inteira, às vezes revoluta, face adaxial glabra, face abaxial esparsamente glanduloso-pontoada, hifódromas. Capitulescência em panículas terminais; invólucro cilíndrico, 5,4-7,2 mm compr., 1,5-3 mm larg., (3-)4seriado; brácteas involucrais 2,5-5,3 mm compr., 0,5$0,9 \mathrm{~mm}$ larg., lanceoladas, ápice cuspidado, margem inteira, face adaxial com estrias longitudinais. Receptáculo cônico, glabro. Capítulo com 21 flores; corola assimétrica com tubo $3 \mathrm{~mm}$ compr., glabro; lacínias 0,6 mm compr., externamente glandulosopontoadas. Anteras com base arredondada, apêndice apical cuspidado, base arredondada. Ramos do estilete com ápice agudo. Cipselas obcônicas, 1,2-1,4 $\mathrm{mm}$ compr., 0,5 mm diâm., costas ciliadas, esparsamente hisutas. Pápus 2,2-3 mm compr.

Material examinado: Minas Gerais, Jaboticatubas, caminho para Capão dos Palmitos, 31.V.1991, bot., fl. e fr., R. Simão-Bianchini \& S. Bianchini CFSC 12741 (HUFU, SPF); Serra do Cipó, km 120, 19.IV.1950, bot. e fl., A.P. Duarte 2492 (HUFU, RB); RPPN Brumas do Espinhaço e Ermo dos Gerais, várzea do Rio das Pedras, 15.V.2012, fl. e fr., I.R. Andrade et al. 465 (BHZB, HUFU); PARNA Serra do Cipó, estrada para a usina depois da pousada Carumbé 19¹8'44,4"S 4337'26,7"W, 4.IV.2009, bot., G.E. Valente et al. 2495 (HUFU, VIC); Santana do Riacho, atalho entre o km 115 e a estrada da usina, 2.V.1993, fl. e fr., V.C. Souza \& C.M. Sakuragui 3403 (ESA, MBM, SPF); Santana do Riacho, arredores do Córrego Chapéu de Sol, 4.VII.1996, fl. e fr., V.C. Souza et. al. 11670 (ESA).

Praxelis capillaris é encontrada em Goiás, Mato Grosso, Mato Grosso do Sul, Minas Gerais, Paraná e São Paulo. Na área ocorre em campo seco pedregoso e campo rupestre. Robinson (2006) cita a proximidade desta espécie com $P$. splettii H.Rob., devido à presença de corola assimétrica, pápus com cerdas iguais e folhas pseudoverticiladas. A espécie é facilmente distinta das demais do gênero por apresentar suas folhas lineares e verticiladas.
11.3 Praxelis clematidea R.M.King \& H.Rob., Phytologia 20 (3): 194. 1970.

Fig. 3C, E

Subarbustos, ca. 0,4 m alt. Ramos cilíndricos, densamente hirsutos. Folhas opostas; pecíolo 2,1-6,2 $\mathrm{mm}$ compr., densamente hirsuto; lâminas 10,2-40 mm compr., 3,2-25,2 mm larg., ovadas ou lanceoladas, ápice agudo, base aguda ou truncada, margem denteada, ambas faces setosas ou hirsutas, face abaxial glanduloso-pontoada, camptódromas ou craspedódromas. Capitulescência em panículas corimbiformes; capítulos com pedúnculo 2,9-5,5 mm compr., densamente hirsuto; invólucro cilíndrico a estreito-campanulado, 6-7,8 $\mathrm{mm}$ compr, 2,6-5 mm larg., 3-5-seriado; brácteas involucrais externas 3,23,7 mm compr., 0,8-1 $\mathrm{mm}$ larg., lanceoladas ou ovado-lanceoladas, ápice longamente acuminado, margem inteira, face adaxial esparso-serícea, as medianas 5,7-7,1 mm compr., 1,3-1,6 mm larg., oblongas, ápice cuspidado ou longo acuminado, arroxeado, margem inteira, às vezes hialina, ápice esparso-serícea, as internas 6,1-8,3 mm compr., 11,1 mm larg., oblongas, ápice cuspidado ou acuminado, arroxeado, margem inteira, às vezes hialina, ápice esparso-serícea. Receptáculo piloso. Capitulo com até 45 flores; corola 3,5-3,9 mm compr.; lacínias 0,4-0,6 mm compr., internamente papilosas. Anteras com base sagitada, apêndice apical lanceolado. Ramos do estilete com ápice agudo ou arredondado, papilosos. Cipselas 1,3-2,1 mm compr., 0,3-0,7 mm diâm., glabrescentes a esparso-pilosas; carpopódio simétrico, anelar. Pápus 3,9-4,2 mm compr.

Material examinado: Minas Gerais, Serra do Cipó, estrada para Conceição do Mato Dentro, aproximadamente km 120, 18.XII.2014, bot. e fl., F.L. Contro 32 \& D. Marques (HUFU); Portaria Principal do Parna Serra do Cipó, 15.XII.2014, bot., fl. e fr., F.L. Contro 04 \& D. Marques (HUFU); Santana do Riacho, distrito de São José da Cachoeira, beira da estrada Santana do Riacho- Santana do Pirapama, 20.II.2007, fl. e fr., V.C. Souza et. al. 32884 (ESA).

Praxelis clematidea ocorre em Goiás, Mato Grosso, Mato Grosso do Sul, Minas Gerais, Paraná e São Paulo. Na área de estudo ocorre em borda de mata e campo rupestre. Dentre as espécies de Praxelis que ocorrem na área, esta é a mais diferente, pois seus capítulos não apresentam as brácteas involucrais facilmente caducas como as demais, seu receptáculo é piloso vs. glabro nas outras e pode ser confundida, algumas vezes, com Barrosoa bentoniciformis (DC.) R.M.King \& H.Rob.

Em alguns herbários também pode ser comumente identificada como Ageratum conyzoides, contudo diferencia-se por apresentar capítulos grandes (até $7,8 \mathrm{~mm}$ ), receptáculo cônico e pápus cerdoso e unisseriado vs. capítulos pequenos (até $4,5 \mathrm{~mm}$ ), receptáculo convexo e pápus coroniforme. 
Flora da Serra do Cipó, Minas Gerais: Asteraceae - Eupatorieae

11.4 Praxelis kleinioides (Kunth) Sch.Bip., Jahresber. Pollichia 22-24: 254. 1866

Subarbustos, ca. 0,5 m alt. Ramos cilíndricos, hirsutos. Folhas opostas, sésseis; lâminas 16,9-62,4 mm compr., 4-19,2 mm larg., elípticas a lanceoladas, ápice agudo, base decorrente, margem serreada ou denteada, face adaxial esparso hirsuto-serícea, face abaxial esparsamente hirsuta, glanduloso-pontoada, acródromas basais. Capitulescência em racemos corimbiformes; capítulos subsésseis ou pedúnculo 0,8-2,3 mm compr., hirsuto-seríceo; invólucro estreitocampanulado, 6,1-7,2 mm compr., 4-6,8 mm larg., 34-seriado; brácteas involucrais com margem inteira, as externas 2,2-2,8 mm compr., 0,7-0,9 mm larg., triangulares, ápice apiculado, as medianas 3,5-3,9 $\mathrm{mm}$ compr., 1,4-1,6 mm larg., oblongas, ápice apiculado, as internas 5,6-6,2 mm compr., 1,1-1,4 $\mathrm{mm}$ larg., oblongo-lineares, ápice curto apiculado. Capítulo com 34-50 flores; corola com tubo 2-2,8 mm compr.; lacínias 0,5-0,7 mm compr., papilosos internamente. Anteras com base sagitada, apêndice apical lanceolado. Ramos do estilete lineares, papilosos. Cipselas 1-2,1 mm compr., 0,3-0,6 mm diâm., seríceas; carpopódio assimétrico. Pápus 1,9$3,5 \mathrm{~mm}$ compr.

Material examinado: Minas Gerais, Santana do Pirapama, Fazenda Inhame, fl., 22.III.1982, J.R. Pirani et al. CFSC 8106 (SP, SPF).

Material adicional examinado: Minas Gerais, Uberlândia, estrada para Campo Florido, a $20 \mathrm{~km}$ do centro da cidade, 27.X.1997, fl., G.M. Araújo 1519 (HUFU); Uberlândia, EEP, 11.OX.1998, fl., A.A.A. Barbosa 1116 (HUFU).

Praxelis kleinioides pode ser encontrada em todos os estados do Brasil e em todos os diminios geográficos. Na área de estudo pode ser encontrada em campos rupestres. Esta espécie se distingue das demais, na área, por apresentar seu invólucro estreitocampanulado e folhas elípticas a lanceoladas e hirsutas. Almeida (2008) compara esta espécie com Chromolaena decumbens pela presença de brácteas involucrais caducas e folhas linear-lanceoladas.

\section{Pseudobrickellia R.M.King \& H.Rob., Phytologia 24: 74. 1972.}

Arbustos a arvoretas, eretos ou com ramos fasciculados. Ramos com cicatrizes da inserção das folhas, glabros ou puberulos. Folhas densamente espiraladas; sésseis ou curto-pecioladas; lâminas lineares ou lanceoladas, glabras ou glandulosopontoadas. Capitulescência terminal, corimbosa a piramidal; pedunculos curtos, glabro a pubérulo; invólucro subimbricado, 2-4-seriado; estramíneas a avermelhadas externamente. Receptáculo plano, epaleaceo. Capítulo com 2-4(-7) flores; corola branca, glabra externamente ou glanduloso-pontoada. Anteras com apêndices ovadas, tão longo quanto largo.
Ramos do estilete clavados, mamilosos, base alargada, hirsuta. Cipselas prismáticas, setosas nas costas; carpopódio distinto, anelar. Pápus cerdoso, (12-seriado, serie externa mais curta.

O gênero apresenta três espécies, restritas aos estados de Goiás e Minas Gerais (King \& Robinson 1987). King \& Robinson (1987) reconhecem como característica marcante do gênero 0 hábito subarbustivo com muitos ramos e folhas densamente espiraladas. O mesmo tipo de habito também é encontrado em Disynaphia, no entanto este apresenta base do estilete não alargada e sem tricomas e ramos do estilete lineares.

$\mathrm{Na}$ área de estudo foram encontradas as três espécies: $P$. angustissima, $P$. brasiliensis e Pseudobrickellia sp.

Chave para as espécies de Pseudobrickellia:

1. Subarbusto cespitoso; capítulos com 6-7

flores .....................................12.3 Pseudobrickellia sp.

1'. Arbustos a arvoretas; capítulos com 4 flores.

2. Folhas lanceoladas; ramos glabros ..................................... $12.1 \mathrm{P}$. angustissima

2'. Folhas lineares; ramos glanduloso-

pontoados ..................................... 12.2 P. brasiliensis

12.1 Pseudobrickellia angustissima (Spreng. ex Baker) R.M.King \& H.Rob., Phytologia 24: 75. 1972.

Arvoreta, 1-1,5 m alt. Ramos glabros. Folhas sésseis; lâminas 4,7-56,5 mm compr., 0,6-1,6 mm larg., lanceoladas, ápice agudo, base decorrente, margem inteira, ambas faces glanduloso-pontoadas, hifódromas. Capitulescência em panículas corimbiformes; capítulos com pedúnculo 1,3-3,5 mm compr., glabro; invólucro cilíndrico 3,4-6,1 mm compr., 1,9-4 mm larg., 3-4-seriado; brácteas involucrais com ápice obtuso, margem inteira, hialina, as externas 11,3 $\mathrm{mm}$ compr., $0,4-0,8 \mathrm{~mm}$ larg., ovadas a triangulares, as internas 5,1-5,5 mm compr., 1-1,22 $\mathrm{mm}$ larg., oblongo-lanceoladas. Receptáculo alveolado, glabro. Capítulo com 4 flores; corola com tubo 2,9-3,5 mm compr.; lacínias 0,2-0,4 mm compr. Anteras com base arredondada. Ramos do estilete lineares, ápice espatado, mamilosos. Cipselas 3,2-3,9 mm compr., 0,8-0,85 mm diâm., 5-costadas; carpopódio simétrico. Pápus 1-seriado, 3,5-4 mm compr.

Material examinado: Minas Gerais, Conceição do Mato Dentro, Serra do Sapo, 16.VI.2008, bot., E.A.E. Guarçoni 1337 \& M.A. Sartori (HSA, HUFU); Rodovia Belo Horizonte-Conceição do Mato Dentro km 119, 31.X.1985, fl. e fr., M. Meguro et al. CFSC 40535 (HUFU, SPF); Santana do Pirapama, perto de Inhame, subida da Serra, 1856'8.6"S 4346'35.6"5W, 27.XI.2009, fl. e fr., W. Milliken 4173 (RB, SPF).

Pseudobrickellia angustissima ocorre na Bahia, Goias, Minas Gerais, Piaui e Distrito Federal, 
em Caatinga e Cerrado. Na área de estudo pode ser encontrada em campo rupestre. King \& Robinson (1972), ao estabelecem o novo gênero Pseudobrickellia, diferenciam $P$. angustissima e $P$. brasiliensis com base no número de costas na cipsela, visto que estas apresentam 5 e 10 costas, respectivamente. Também relacionam a presença de estilopódio alargado em $P$. angustissima, porém tal característica não foi observada nos espécimes da Serra do Cipó.

12.2 Pseudobrickellia brasiliensis (Spreng.) R.M.King \& H.Rob., Phytologia 24: 75. 1972.

Arbusto a arvoreta, 1,5-1,7 m alt. Ramos multicostados, glanduloso-pontoados. Folhas sésseis; lâminas 0,45-1,8 mm compr., 0,04-0,1 cm larg., lineares, ápice agudo, base decorrente, margem inteira, face adaxial glanduloso-pontoada, face abaxial esparsamente serícea, glanduloso-pontoada, hifódromas. Capitulescência em panículas corimbiformes; capítulos com pedúnculo 1,2-5,7 mm compr., glanduloso-pontoado; invólucro cilíndrico, 3seriado; brácteas involucrais com ápice agudo, margem fimbriada, as externas 0,9-1,4 mm compr., 0,7-1,1 mm larg., ovadas, face adaxial com ápice glanduloso-pontoado, as internas 5,1-6 mm compr., 1,3-1,4 mm larg., lanceoladas. Receptáculo alveolado. Capítulo com 4 flores; corola com tubo 4,4-4,7 mm compr.; lacínias 0,7-1,1 mm compr. Anteras com base sagitada. Ramos do estilete claviformes, mamilosos. Cipselas 3,3-4 mm compr., 1,1-1,3 mm diâm., 10costada, seríceas; carpopódio simétrico. Pápus 1seriado, 4,2-4,9 $\mathrm{mm}$ compr.

Material examinado: Minas Gerais, Santana do Riacho, PARNA Serra do Cipó, Serra das Badeirinhas, 27.VII.1991, fl e fr., A.M. Giulietti CFSC 12479 (HUFU, SPF); PARNA Serra do Cipó, Canyon, Ribeirão Bandeirinhas, 30.VII.1988, fl. e fr., C. Kameyama et al. CFSC 11222 (HUFU, SPF); Jaboticatubas, VII.1949, bot. e fl., J. Vidal s.n. (R 152710); Santana do Riacho, PARNA Serra do Cipó, descida da Serra das Bandeirinhas, 28.VII.1991, fl. e fr., A.M. Giulietti et al. CFSC 12624 (HUFU, SPF); Serra do Cipó, km 110, 23.VIII.1933, fl. e fr., Mello Barreto 3837 (BHCB); Serra do Cipó, km 119, 6.VIII.1936, fl. e fr., Mello Barreto 4971 (BHCB); Santa Luzia, Serra do Cipó, km 128, Palácio, 3.IX.1933, fl. e fr., Mello Barreto 3912 (BHCB); Serra do Cipó, km 112-128 ao longo da rodovia do Hotel Chapéu de Sol, 7.VIII.1960, bot. e fl., B. Maguire et al. s.n. (NY 49080, RB 116276)

Pseudobrickellia brasiliensis ocorre na Bahia, Ceará, Maranhão, Mato Grosso, Mato Grosso do Sul, Minas Gerais, Pará, Piauí, Rondônia, São Paulo, Tocantins e Distrito Federal, nos domínios da Amazônia e Cerrado. Na área de estudo pode ser encontrada em campo rupestre. A espécie é muito semelhante à $P$. angustissima e a principal diferença entre as duas é presença de folhas lanceoladas nesta e lineares em $P$. angustissima.

\subsection{Pseudobrickellia sp.}

Fig. 3E-H

Subarbusto ramificado, 0,3-0,4 m alt. Ramos decorticantes, multicostados, glabros. Folhas sésseis; lâminas 4,8-11,1 mm compr., 0,4-1,4 mm larg., lineares, ápice obtuso a arredondado, base semiamplexicaule, margem inteira, ambas faces glabras, vernicosas, hifódromas. Capitulescência em racemos solitários; capítulos com pedúnculo 3-12,2 $\mathrm{mm}$ compr., tricomas em forma de cone; invólucro campanulado, 10,3-13,3 mm compr., 4,7-7,2 mm larg., 2(-3)-seriado; brácteas involucrais 7,6-11 mm compr., 1,25-3 mm larg., lanceoladas a linearlanceoladas, ápice agudo a longo acuminado, margem inteira, face adaxial coberta por tricomas glandulares. Capítulo com 6-7 flores; corola com tubo 7-7,5 mm compr., glanduloso-pontoado; limbo indiferenciado; lacínias ca. 0,9 mm compr., glanduloso-pontoadas externamente. Anteras com base arredondada, ápice lanceolado. Ramos do estilete lineares, mamilosos, ápice espessado. Cipselas 1,9-2,1 mm compr., 0,50,9 mm diâm., ápice afilado; carpopódio simétrico. Pápus 1-seriado, 9,2-9,7 mm compr., cerdas avermelhadas.

Material examinado: Minas Gerais, Estrada de Lapinha da Serra para RPPN Brumas do Espinhaço, 19॰03'59"S 4342'24"W, 2.VII.2015, fl., F.L. Contro et al. 137 (HUFU); RPPN Brumas do Espinhaço, estrada para a sede, aproximadamente $400 \mathrm{~m}$ da porteira, $19^{\circ} 03^{\prime} 53^{\prime \prime S} 43^{\circ} 42^{\prime} 25^{\prime \prime} \mathrm{W}$, 3.VII.2015, fl., F.L. Contro et al. 163 (HUFU); PARNA Serra do Cipó, Serra das Bandeirinhas, 27.VII.1991, fl. e fr., A.M. Giulietti et al. CFSC 12479 (HUFU, SPF); Itambé do Mato Dentro, Serra das Bandeirinhas $19^{\circ} 24^{\prime} 40^{\prime \prime}-30^{\circ} 00^{\prime} S$ $43^{\circ} 29^{\prime} 40^{\prime \prime}-34^{\circ} 00^{\prime}$ W, 11-14.V.1982, bot. e fl., N. Hensold 817 (SPF)

Material adicional examinado: Minas Gerais, São Roque de Minas, Garagem das Pedras, PARNA Serra da Canastra, 19.III.1995, bot. e fl., R. Romero et al. 2632 (DIAM, HUFU, MBM); PARNA Serra da Canastra, morro próximo à sede administrativa, 15.VII.1995, bot. e fl., R. Romero et al. 2355 (DIAM, HUFU, MBM).

A espécie pode ser encontrada em áreas de campo limpo com afloramentos rochosos. A espécie diferencia-se das outras duas encontradas na área pelo hábito subarbustivo bastante ramificado, folhas pequenas (até 1,1 cm), ramos levemente decorticantes, capítulos creme com 6-7 flores e cerdas do pápus avermelhadas vs hábito arbustivo, folhas grandes, capítulos castanho-amarronzados com 4 flores e cerdas do pápus alvas, em $P$. angustissima e $P$. brasiliensis.

Não foi possível a identificação deste material a nível espécifico, uma vez que suas características são totalmente distintas das outras existentes no gênero, mas tanto a bibliografia quanto consultas a especialistas não permitiram sua identificação até o momento. Nakajima (2000) já a citou como possivel espécie nova, porém mais estudos são necessários. 
13. Stevia Cav., Icon. 4 (1): 32, pl. 354. 1797.

Ervas ou arbustos, anuais ou perenes. Ramos cilíndricos a levemente hexagonais, multicostados, glabros a pubescentes. Folhas opostas ou alternas, sésseis ou pecioladas; lâminas lineares a orbiculares, margem inteira, serreada ou dentada, pubérula, tricomas glandulares estipitados, glanduloso-pontoadas. Capitulescência em corimbos densos; capítulos pedunculados; invólucro eximbricado, 2-seriado; brácteas involucrais 5, (3 externas, 2 internas). Receptáculo plano a levemente convexo, epaleaceo. Capítulos com 5 flores; corola funeiforme, brancas, lilás ou arroxeadas, lacínias triangulares a oblongo-ovadas, papilosas internamente. Anteras com colar cilíndrico, apêndice obovado, margem apical crenulada. Ramos do estilete filiformes, lineares, papilosos ou mamilosos, base levemente alargada. Cipselas fusiformes a prismáticas, glandulosas ou setosas; carpopódio assimétrico. Pápus 1-2-seriado, paleáceo, aristado ou coroniforme.

King \& Robinson (1987) reconhecem 230 espécies no gênero, distribuídas no sudeste dos Estados Unidos, México, América Central e do Sul (regiões extra-amazônicas) e Argentina. No Brasil são aceitas 32 espécies, das quais 25 são endêmicas, distribuídas pela Bahia, Espírito Santo, Goiás, Mato Grosso do Sul, Minas Gerais, Paraná, Rio de Janeiro, Santa Catarina, São Paulo e Distrito Federal, em Cerrado, Mata Atlântica e Pampa.

Stevia é um dos gêneros mais reconhecíveis da tribo pela presença de invólucro com 5 brácteas e capítulos com 5 flores. Na área de estudo foram encontradas três espécies: $S$. collina, $S$ heptachaeta e S. urticaefolia.

\section{Chave para as espécies de Stevia}

1. Capitulescência em panículas corimbiformes, pedúnculos tomentosos; cipsela glanduloso-

pontoada ................................................ 13.1 S. collina

1'. Capitulescência em panículas de dicásio, pedúnculos com tricomas glandulares; cipsela glabra.

2. Lâminas camptódromas; receptáculo

plano ...........................................13.2 S. heptachaeta

2'. Lâminas acródromas basais ou

actinódromas; receptáculo convexo ....13.3 S. urticifolia

13.1 Stevia collina Gardner, London J. Bot. 5: 458. 1846.

Subarbustos, 0,6 m alt. Ramos cilíndricos, tomentosos, glanduloso-pontoados. Folhas opostas, sésseis; lâminas $0,5-3 \mathrm{~cm}$ compr., $0,1-1 \mathrm{~cm}$ larg., lanceoladas, ápice agudo, base decurrente, margem serreada, inteira nas folhas jovens, ambas faces tomentosas, glanduloso-pontoada, paralelódromas.
Capitulescência em panículas corimbiformes; capítulos com pedúnculo 1-7,5 mm compr., densamente tomentoso; invólucro cilíndrico-campanulado, 4,6-8,3 $\mathrm{mm}$ compr., 2,7-3,5 $\mathrm{mm}$ larg.; brácteas involucrais 6,4-8 $\mathrm{mm}$ compr., $1,2-1,3 \mathrm{~mm}$ larg., lanceoladas, ápice acuminado, margem inteira, ciliada, face adaxial glanduloso-pontoada, tomentosa. Receptáculo plano, glabro. Corola com tubo 2,6-4,5 mm compr., tomentoso, glanduloso-pontoado; lacínias $0,8-1,1 \mathrm{~mm}$ compr., tomentosas. Anteras com apêndice apical emarginado, base arredondada. Ramos do estilete lineares, mamilosos. Cipselas prismáticas, 2,7-3,2 mm compr., 0,5-0,7 mm diâm., glanduloso-pontoadas; carpopódio anelar. Pápus aristado, 1-seriado, 4,5-5 $\mathrm{mm}$ compr., ca. 10 aristas, espessadas na base.

Material examinado: Minas Gerais, Serra do Cipó, km 112, fl. e fr., 16.IV.1965, A.P. Duarte 9136 (RB).

Material adicional examinado: Minas Gerais, Uberlândia, EEP, IX.1992, fl., A.A.A. Barbosa 487 (HUFU); EEP, 26.III.1999, fl., G.M. Araújo 2360 (HUFU).

Stevia collina ocorre em Goiás, Minas Gerais, Paraná, Rio Grande do Sul, Santa Catarina e São Paulo, em Cerrado. Na área de estudo pode ser encontrada em áreas de campo limpo. A espécie pode ser reconhecida por apresentar suas lâminas, brácteas involucrais e corola tomentosas, cipsela prismática e pápus com aristas espessas na base.

Diferencia-se de $S$. urticifolia, outra espécie do gênero existente na área, por apresentar suas capitulescências em panículas corimbiformes, pedúnculo tomentoso e pápus 1-seriado (vs. capitulescência em panículas de dicásio, pedúnculos com tricomas glandulares e pápus 2-seriado).

13.2 Stevia heptachaeta DC., Prodr. 5: 122. 1836. Fig. 3l, J

Subarbustos, 0,6 m alt. Ramos cilíndricos, multicostados, tricomas glandulares. Folhas opostas ou verticiladas, sésseis; lâminas $0,6-2,9 \mathrm{~cm}$ compr., $0,1-1,6 \mathrm{~cm}$ larg., ovadas, ápice agudo ou obtuso, base decurrente, margem serreada ou denteada, serícea, ambas faces glanduloso-pontoadas, camptódromas. Capitulescência em panículas de dicásios; capítulos subsésseis ou pedúnculo 0,7-3,9 $\mathrm{mm}$ compr., tricomas glandulares; invólucro cilíndrico, 4,5-6,8 mm compr., 1,5-3,3 mm larg.; brácteas involucrais 5-6,3 $\mathrm{mm}$ compr., 0,6-1,6 mm larg., lanceoladas, ápice agudo, margem inteira, face adaxial com tricomas glandulares. Receptáculo plano, glabro. Corola com tubo 4,2-4,9 mm compr., glabro; lacínias 0,7-1 mm compr., esparsamente serícea na face externa. Anteras com base obtusa, ápice obtuso. Ramos do estilete lineares, mamilosos. Cipselas cilíndricas, rostradas ou estipitadas, $1,5-3,2 \mathrm{~mm}$ compr., $0,1-0,5$ $\mathrm{mm}$ diâm., glabras; carpopódio anelar. Pápus 2seriado, série externa paleácea, 0,5-0,6 mm compr., série interna 3-aristada, 6-6,2 mm compr. 


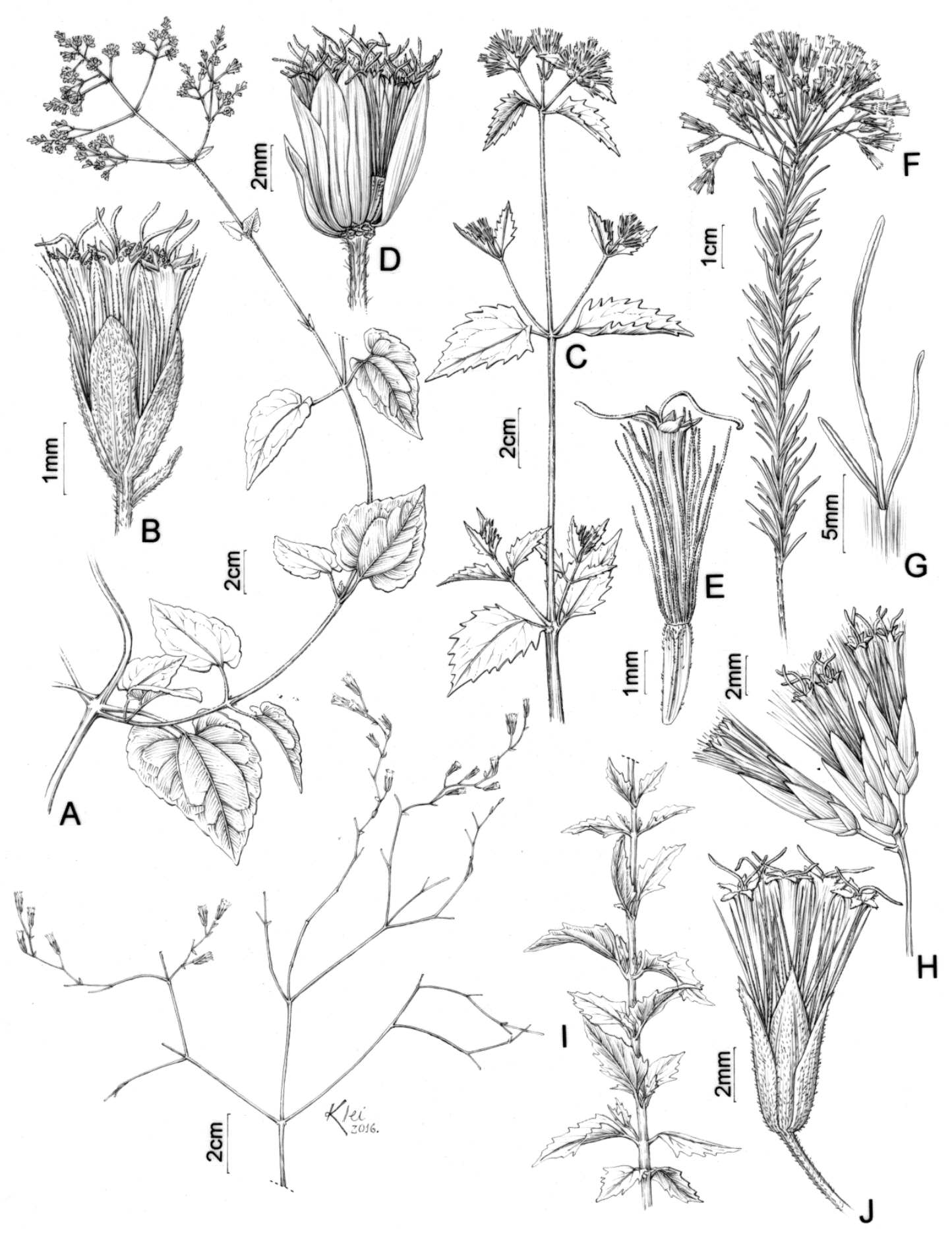

Fig. 3: A-B. Mikania microcephala DC. A. Ramo. B. Capítulo. C-E. Praxelis clematidea R.M.King \& H.Rob. C. Ramo. D. Capítulo. E. Cipsela e pápus. F-H. Pseudobrickellia sp. F. Ramo. G. Detalhe das folhas. H. Capítulo e invóluvro. I-J. Stevia heptachaeta DC. I. Ramo. J. Capítulo (A. F.L.Contro 59; C. F.L.Contro 32; F. A.Resende 65; I. F.L.Contro 134). 
Material examinado: Minas Gerais, Jaboticatubas, Serra do Cipó, km 130, 23.IIl.1940, fl. e fr., Mello Barreto 10848 (BHCB, ESA).

Material adicional examinado: Goiás, Cocalzinho, Serra dos Pirineus, Cidade de Pedra, trilha da entrada principal, 17.III.2007, fl., P.G. Delprete 10086 (HUFU); Minas Gerais, Diamantina, Parque Estadual do Biribiri, estrada Diamantina-Medanha, cerca de $10 \mathrm{~km}$ do campus JK, Lapa do Forno, 19.V.2011, fl., I.M. Araújo 113 (HUFU).

Stevia heptachaeta pode ser encontrada em Goiás, Minas Gerais, Paraná, Rio de Janeiro e São Paulo, em Cerrado. Na área de estudo ocorre em campos rupestres. É similar à $S$. urticifolia pelo arranjo e disposição das capitulescências e indumento dos pedúnculos, no entanto de diferencia pela presença de lacínias seríceas, ramos do estilete mamilosos e cipselas rostradas (vs. lacínias com tricomas glandulares e hirsutas, ramos do estilete papilosos e cipselas prismáticas).

13.3 Stevia urticifolia Thunb., PI. Bras. 1: 13. 1817.

Arbustos, $1 \mathrm{~m}$ alt. Ramos cilíndricos, estriados, hirsutos. Folhas opostas, sésseis; lâminas 2,2-54,8 mm compr., 1,1-9,4 mm larg., ovadas ou lanceoladas, ápice agudo, base decorrente, margem serreada, ambas faces glanduloso-pontoadas, esparsamente pubescentes, acródromas basais ou actinódromas. Capitulescência em panículas de dicásio; capítulos com pedúnculo 2,4-10,7 mm compr., densamente com tricomas glandulares; invólucro cilíndrico, 5,4-6,8 mm compr., 1-2,1 mm larg.; brácteas involucrais 4,2-5,1 mm compr., 1-1,4 $\mathrm{mm}$ larg., lanceoladas, ápice agudo, margem inteira, face adaxial densamente com tricomas glandulares. Receptáculo convexo, glabro. Corola com fauce alargada, tricomas glandulares, 3,3-3,8 mm compr.; lacínias 0,4-0,8 $\mathrm{mm}$ compr., tricomas glandulares, esparsamente hirsuta externamente, papilosas internamente. Anteras com base sagitada, ápice obtuso. Ramos do estilete lineares, ápice agudo. Cipselas prismáticas, 1,6-2,4 mm compr., 0,2-0,4 mm diâm., glabras, carpopódio anelar. Pápus 2-seriado, série externa curta, paleácea, 0,3-0,5 mm compr., série interna aristada.

Material examinado: Minas Gerais, Jaboticatubas, 6 $\mathrm{km}$ ao norte do Palácio, $19^{\circ} 10^{\prime} \mathrm{S}$ e $43^{\circ} 35^{\prime} \mathrm{W}$, fl., 29.IV.1952, L.B. Smith et al. 6873 (R); PARNA Serra do Cipó, altura do km 129, 19.IV.1950, bot. e fl., A.P. Duarte 2570 (HUFU, RB); Estrada Lapinha da Serra-RPPN Brumas do Espinhaço, 1903'59"S 4342'24"W, 2.VII.2015, fl. e fr., F.L. Contro et al. 134 (HUFU); Jaboticatubas, Serra do Cipó, km 130, 23.III.1940, fl. e fr., Mello Barreto 10848 (BHCB); Santana do Riacho, proximidades da estátua do Juquinha, rodovia MG 010, km 122, 9.V.2012, fl., C. Delfini et. al. 216 (ESA).

Stevia urticifolia pode ser encontrada em Goiás e Minas Gerais, em Cerrado. Na área de estudo pode ser encontrada em campos rupestres e margem de capão. Almeida (2008) compara esta espécie com
S. camporum Baker, pelo arranjo dos capítulos em panículas corimbiformes, flores menores, corola com lacínias glandulosas.

\section{Stomatanthes R.M.King \& H.Rob., Phytologia 19: 430. 1970.}

Ervas ou subarbustos perenes, pouco a densamente ramificados. Ramos cilíndricos, estriados. Folhas alternas, opostas ou verticiladas, curtopecioladas; lâminas elípticas, oblanceoladas, ovadas ou orbiculares, margem inteira a denteada. Capitulescência piramidal a panículas tirsoides; capítulos pedunculados ou sésseis; invólucro eximbricado a fracamente subimbricado, 2-3-seriado. Receptáculo convexo, plano-alveolado, glabro. Capítulo com 4-11 flores; corola funeiforme a tubulosa, branca, glabra ou glandulosa com poucos tricomas, lacínias triangulares. Anteras com apêndices ovados ou oblongos, colar cilíndrico. Ramos do estilete lineares a filiformes ou clavados, papilosos, base alargada ou não, com muitos tricomas. Cipselas prismáticas, densamente setosas ou glandulosas; carpopódio distinto. Pápus cerdoso, persistente, cerdas com ápice obtuso ou agudo.

King \& Ronbinson (1987) reconhecem 15 espécies para o gênero, distribuídas pela África e América do Sul. No Brasil são aceitas 13 espécies, das quais 11 são endêmicas, distribuídas pela Amazônia, Caatinga, Cerrado e Pampa.

A característica mais marcante do gênero é a presença de ramos do estilete clavados ou claviformes. King \& Robinson (1987) citam como característica forte do gênero a presença, às vezes, de estômatos na corola, fato não ocorrente em todas as espécies do gênero. $\mathrm{Na}$ área de estudo foi encontrada somente uma espécie.

14.1 Stomatanthes polycephalus (Sch.Bip. ex B.L.Rob.) H.Rob., Phytologia 20: 337. 1970.

Fig. 4A, B

Arbustos, 0,8-1,6 m alt. Ramos cilíndricos, multicostados, tomentosos. Folhas alternas, sésseis; lâminas 0,8-4,1 cm compr., 0,3-1 cm larg., lanceoladas, ápice mucronado, base amplexicaule, margem inteira, ambas faces densamente tomentosas, broquidódromas. Capitulescência em paniculas globosas; capítulos sésseis; invólucro campanulado, 2,7-4 mm compr., 2,5-4,1 mm larg., 2-3-seriado; brácteas involucrais com margem inteira, as externas 1,9-2 mm compr., 0,6-0,8 mm larg., ovadolanceoladas, ápice longo acuminado ou apiculado, densamente seríceo, margem ciliada, as internas 4,65,2 mm compr., 1,1-1,3 mm larg., lanceoladas, ápice apiculado, margem fimbriada, hialina, face adaxial esparso-tomentosa. Receptáculo plano-alveolado, glabro. Capítulo com 5-6 flores; corola com tubo 0,6$1,2 \mathrm{~mm}$ compr., glanduloso-pontoado; limbo 1,6-2,3 
$\mathrm{mm}$ compr., glabro; lacínias 0,3-0,5 mm compr., glanduloso-pontoadas externamente, papilosas internamente. Anteras com base arredondada, apêndice apical oblongo, ápice emarginado. Ramos do estilete claviformes, estilopodio alargado com tricomas. Cipselas 0,5-1,1 mm compr., 0,2-0,4 $\mathrm{mm}$ diâm., pilosas, glanduloso-pontoadas, densamente seríceas na base; carpopódio assimétrico, anelar. Pápus 2-seriado, 2,4-4 mm compr., cerdas com ápice agudo.

Material examinado: Minas Gerais, Santana do Riacho, $19^{\circ} 18^{\prime}$ S $43^{\circ} 36^{\prime} \mathrm{W}, 6 . X \mathrm{XI} .1981$, fl. e fr., G.C.P. Pinto 365/81 (MBM).

Material adicional examinado: Minas Gerais, Diamantina, Parque Estadual do Biribiri, Nascente da Água Limpa, 19.IX.2012, fl., I.M. Franco 1081 (HUFU); Cadeia do Espinhaço, estrada que leva ao Parque Estadual do Rio Preto, área de amortecimento, 13.VIII.2013, fl., D.A. Chaves 32 (HUFU).

Stomatanthes polycephalus ocorre em Goiás, Mato Grosso, Mato Grosso do Sul, Minas Gerais e São Paulo, em áreas de Cerrado. $\mathrm{Na}$ área de estudo pode ser encontrada em savana aberta. A espécie pode ser reconhecida por apresentar os ramos do estilete claviformes e base do estilete alargada com tricomas.

15. Symphyopappus Turcz., Bull. Soc. Imp. Naturalistes Moscou 21 (1): 583. 1848.

Arbustos eretos ou arvoretas, moderadamente ramificados. Ramos cilíndricos, estriados, esparso-pubérulos, geralmente viscosos. Folhas opostas, às vezes alternas próximas à capitulescência; subsésseis a curto-pecioladas; lâmina geralmente oval-lanceolada, margens serradas, nervura central proeminente ou esculpida em ambas as faces. Capitulescência terminal, geralmente denso corimbosa; capítulos curto-pedunculados, glabros, com costas proeminentes; geralmente com uma ou mais brácteas subinvolucrais longas, estreitas, mais espessas, avermelhadas a nigrescentes formando uma serie mais externa; brácteas involucrais ca. 15, subimbricadas, 3-4(-5) seriadas; internas desiguais e gradualmente maiores, subestramineas, geralmente persistentes; receptáculo plano ou levemente convexo, glabro, glabro ou com numerosos tricomas rígidos. Capítulos com 5-10 flores; corola levemente alargada no limbo, raramente estreito-funeiforme, com base do tubo alargada; lobos triangulares a oblongotriangulares, levemente mais comprido do que largo a duas vezes mais comprido do que largo, superfície interna lisa, externa papilosa no ápice, geralmente com poucas glândulas próximo ao ápice ou mesmo glabros. Antera com colar curto, cilíndrico, base aguda ou obtusa, apêndice do conectivo triangular, duas vezes mais comprido do que largo, estilete com base não alargada, glabra. Ramos do estilete lineares, cobertos de papilas curtas, mamilosos. Cipselas curto- prismáticas, 4-5-costada, glabra ou com poucos tricomas glandulares estipitados; carpopódio curtocilindrico. Pápus geralmente em duas séries, unidas na base formando um anel, geralmente caindo como uma unidade, cerdas com células apicais agudas a obtusas.

No Brasil existem 13 espécies distribuídas nos estados da Bahia, Espírito Santo, Goiás, Minas Gerais, Paraná, Rio de Janeiro, Rio Grande do Sul, Santa Catarina, São Paulo e Distrito Federal. O gênero é caracterizado por apresentar seus capítulos com, geralmente, cinco flores (raramente 10, em $S$. decemflorus) e cerdas do pápus unidas na base formando um anel. $\mathrm{Na}$ área de estudo foram encontradas seis espécies.

\section{Chave para as espécies de Symphyopappus}

1. Cerdas do pápus com ápice em forma de gancho ............................................ 15.6 S. uncinatus 1'. Cerdas do pápus com ápice reto.

2. Folhas sésseis.

3. Cipsela cilíndrica ......................15.1 S. brasiliensis

3'. Cipselas prismáticas ou obcônicas.

4. Ramos castanhos; lâminas foliares com margem denteada na metade superior, paralelódromas .................

4'. Ramos levemente avermelhados, vernicosos; lâminas foliares com margem serreada, nervuras reticuladas 15.4 S. decussatus

2'. Folhas pecioladas.

5. Lâmina estreito-elíptica, base aguda; ramos do estilete mamilosos; carpopódio indistinto ................................ 15.2 S. compressus

5'. Lâmina elíptica, base cuneada; ramos do estilete papilosos; carpopódio distinto 15.3 S. cuneatus

15.1 Symphyopappus brasiliensis (Gardner) R.M.King \& H.Rob., Phytologia 39: 134. 1978.

Sinônimo: Symphyopappus reticulatus Baker in Mart., FI. Bras. 6 (2): 367. 1876.

Subarbustos a arvoretas, $1 \mathrm{~m}$ alt. Ramos multicostados, glabros, vernicosos. Folhas opostascruzadas, sésseis, lâminas 1,3-4,4 cm compr., 0,3-1,2 cm larg., lanceoladas a obovadas, ápice agudo a longo acuminado, base aguda ou atenuada, decorrente, margem fortemente denteada no terço superior, ambas faces glanduloso-pontoadas, às vezes face adaxial vernicosa, peninérveas. Capitulescência em panículas corimbiformes; capítulos com pedúnculo 0,5-3,2 $\mathrm{mm}$ compr., glabros, vernicosos; invólucro estreito-campanulado, 4-8,3 mm compr., 1,7-4,9 mm larg., 3-4-seriado; brácteas involucrais 1,4- 5,3 mm compr., 0,9-2,8 mm larg., externas triangulares, ápice agudo, margem serrilhada, internas oblongas a oblongo-lanceoladas, ápice obtuso a arredondado, margem ciliada. 
Receptáculo plano, glabro. Capítulo com 5 flores; corola com tubo 1,6-2,8 mm compr., glabro; lacínias 0,4-0,6 mm compr., glanduloso-pontoadas externamente. Anteras com base sagitada, apêndice apical lanceolado. Ramos do estilete lineares, mamilosos. Cipselas cilíndricas, levemente rostradas, 1,6-2,3 mm compr., 0,5-0,9 mm diâm., ápice glanduloso-pontoado; carpopódio simétrico, anelar. Pápus 2-seriado, 2,5-3 mm compr.

Material examinado: Minas Gerais, Serra do Cipó, estrada para Conceição do Mato Dentro, aproximadamente km 120, 18.XII.2014, bot. e fl., F.L. Contro 31 \& D. Marques (HUFU); Estrada para Conceição do Mato Dentro, 19²2'49"S 4340'13"W, 29.VI.2015, fl. e fr., F.L. Contro et al. 63 (HUFU); Serra do Cipó, estrada da usina, 9.I.1981, bot. e fl., N.M. Castro s.n. (HUFU 118); Santana do Pirapama, fazenda Toucán Cipó, seguindo a cerca, 1900'38.01"S 4345'47"W, 21.XI.2009, bot. e fl., D.C. Zappi 2470 (RB, SPF); Santana do Riacho, estrada de Lagoa Santa - Conceição do Mato Dentro, Km 109, 1.II.1987, bot. e fl., T. Wendt et al. 83 (RB); Satnana do Riacho, Morro do Breu, 1904'20"-05'20"S 43³9'20"-40'20"W, 16-17.Il.1982, bot., fl. e fr., N. Hensold 461 (MBM); Santana do Pirapama, Distrito de São José da Cachoeira, trilha de captação da Fazenda Toucán Cipó, 1900'22"S 4345'20"W, 17.II.2007, bot. e fl., V.C. Souza et. al. 32561 (ESA).

Symphyopappus brasiliensis é encontrada somente em Minas Gerais, em Cerrado. Na área de estudo distribui-se em áreas de campo rupestre. Hattori (2014) aproxima esta espécie de Symphyoappus reticulatus Baker devido às folhas elípticas com margem serreada, porém difere da mesma por apresentar suas folhas menores (até 4 $\mathrm{cm}$ ), todas opostas e cruzadas ( $v s$. folhas grandes com $10 \mathrm{~cm}$ e folhas opostas e alternas na mesma planta).

Hattori (2014) sinonimiza algumas espécies à $S$. brasiliensis, sendo estas: $S$. reticulatus Baker, $S$. reticulatus var. itacolumiensis Sch.Bip. ex Baker, $S$. viscosus Sch.Bip. ex Baker e $S$. angustifolius Cabrera. A sinonimização é proposta com base na falta de caracteres morfológicos diagnósticos que diferenciem estas espécies, sendo que a principal fonte de diferenciação entre estas é o tamanho da lâmina foliar, caracter bastante plástico e variável (Hattori, 2014). Neste trabalho adotamos a sinonimização proposta por Hattori (2014) para S. reticulatus.

15.2 Symphyopappus compressus (Gardner) B.L.Rob., Contr. Gray Herb. 80: 12. 1928.

Arbustos, $2 \mathrm{~m}$ alt. Ramos multicostados, glanduloso-pontoados. Folhas opostas, decussadas; pecíolo 11,2-18,5 mm compr., glabro; lâminas 8,310,2 mm compr., 2,4-3,2 cm larg., estreito-elípticas, ápice agudo, base aguda, margem serreada, ambas faces glanduloso-pontoadas, paralelódromas. Capitulescência em panículas corimbiformes; capítulos com pedúnculo 1,6-3,5 mm compr., esparsamente glanduloso-pontoado; invólucro cilíndrico, 3-4-seriado; brácteas involucrais com ápice arredondado, margem inteira, hialina, as externas 4,6-5,4 mm compr., 1,92,3 mm larg., oblongo-lanceoladas, as internas e medianas 7,1-7,4 mm compr., 1,7-2,3 mm larg., oblongo-lanceoladas. Receptáculo plano, fimbriado. Capítulo com 5 flores; corola com tubo 3,8-4,2 mm compr., glabro; lacínias $0,6 \mathrm{~mm}$ compr., glandulosopontoadas. Anteras com apêndice apical elíptico, base curtamente sagitada. Ramos do estilete lineares, mamilosos. Cipselas 3,2-3,6 mm compr., 1,1-1,4 mm diâm., glanduloso-pontoadas; carpopódio indistinto. Pápus 1-seriado, 3,3-4,3 mm compr.

Material examinado: Minas Gerais, Serra do Cipó,

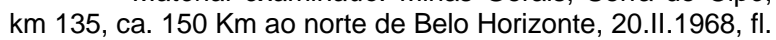
e fr., H.S. Irwin et al. s.n. (RB 150420); RPPN Brumas do Espinhaço, estrada para a sede a aproximadamente $400 \mathrm{~m}$ da porteira, $19^{\circ} 03^{\prime} 53^{\prime \prime S} 43^{\circ} 42^{\prime} 25^{\prime \prime W}$, 3.VII.2015, fl., F.L. Contro et al. 153 (HUFU); PARNA Serra do Cipó, trilha do Cânion das Bandeirinhas, 16.XII.2014, bot. e fl., F.L. Contro 9 \& D. Marques (HUFU); Santana do Riacho, PARNA Serra do Cipó, 19¹8'05"S 4336'03"W, 7.XII.2010, bot. e fl., A.C. Fernandes et al. 297 (BHCB).

Symphyopappus compressus distribui-se pela Bahia, Espírito Santo, Goiás, Minas Gerais, Paraná, Rio de Janeiro, Rio Grande do Sul, Santa Catarina, São Paulo e Distrito Federal, em Caatinga, Cerrado e Mata Atlântica. $\mathrm{Na}$ área de estudo pode ser encontrada em cerrado. Pode ser reconhecida por apresentar folhas com a base aguda e receptáculo fimbriado ou piloso.

É semelhante à $S$. cuneatus pela forma da lâmina, venação foliar e arranjo das capitulescências, no entanto $S$. cuneatus apresenta base da folha cuneada, receptáculo glabro e ramos do estilete papilosos (vs. base da folha aguda, receptáculo fimbriado e ramos do estilete mamilosos).

15.3 Symphyopappus cuneatus (DC.) Sch.Bip., FI. Bras. 6 (2): 367.1876.

Arbusto, ca. 0,4 m alt. Ramos estriados, glanduloso-pontoados. Folhas opostas; pecíolo 0,81,8 mm compr., lâminas 0,5-4,3 cm compr., 0,2-2,2 cm larg., elípticas, ápice agudo, base cuneada, margem serreada, terço inferior inteira, ambas faces glanduloso-pontoadas, paralelódromas. Capitulescência em panículas corimbiformes terminais; invólucro cilíndrico, 3-5-seriado; bráctea subinvolucral linear, 4,8 mm compr., 0,5 mm larg., ápice agudo, glanduloso-pontoada; brácteas involucrais externas 1,5-0,9 mm compr., ovadas, ápice arredondado, margens fimbriadas, as medianas 2,5-2,8 mm compr., 1,3 mm larg., oblongas, ápice arredondado, ciliado, margem inteira, as internas 55,9 mm compr., 2-2,5 mm larg., oblongas, ápice arredondado, ciliado. Receptáculo plano, fimbriado. Capítulo com 5 flores; corola glabra, tubo $2,5 \mathrm{~mm}$ compr.; lobos 0,5 mm compr. Anteras apêndice apical lanceolado, base curtamente sagitada. Ramos do estilete com ápice arredondado, papilosos. Cipselas obcônicas, 2-2,7 mm compr., 1-1,3 mm diâm., 
glanduloso-pontoadas, carpopódio conspícuo. Pápus cerdoso, 1-seriado, 2,4-2,7 mm compr., cerdas espessadas, fundidas na base.

Material examinado: Minas Gerais, Congonhas do Norte, Serra Talhada a $6 \mathrm{~km}$ da estrada Congonhas do Norte-

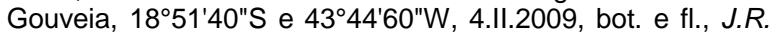
Pirani et al. 5770 (SPF); PARNA Serra do Cipó, 16.l.1951, fl. e fr., J.G. Kuhlmann 30 \& L. Edmundo (HUFU, RB); PARNA Serra do Cipó, trilha para capão e cahoeiras, cerca de $1 \mathrm{~km}$ da portaria do parque, 15.XII.2014, bot. e fl., F.L. Contro 05 \& D. Marques (HUFU); Serra do Cipó, km 110, 5.l.1996, bot., fl. e fr., G.W. Fernandes s.n. (BHCB 106426); Serra do Cipó, km 110, IV.1996, bot., fl. e fr., G.W. Fernandes s.n. (BHCB 106495); Jaboticatubas, km 113 ao longo da rodovia Lagoa Santa-Conceição do Mato Dentro, 7.II.1972, fl. e fr., J. Semir \& M. Sazima s.n. (MBM 56793).

Symphyopappus cuneatus pode ser encontrada em Minas Gerais, Paraná, Rio de Janeiro, Rio Grande do Sul, Santa Catarina e São Paulo, em Cerrado e Mata Atlântica. Na área de estudo ocorre em campo rupestre. É uma espécie que pode ser reconhecida pela forma da base das lâminas foliares que é cuneada.

15.4 Symphyopappus decussatus Turcz., Bull. Soc. Imp. Naturalistes Moscou 21: 584.1848.

Arbustos, até $0,8 \mathrm{~m}$ alt. Ramos cilíndricos, multicostados, glabros, vernicosos. Folhas opostas, decussadas, sésseis; lâminas 2,1-3,1 cm compr., 0,9$1,7 \mathrm{~cm}$ larg., elípticas a amplo-elípticas, ápice agudo, base decorrente a aguda, margem serreada, ambas faces glanduloso-pontoadas, vernicosas, nervuras terciárias reticuladas. Capitulescência em panículas corimbiformes; capítulos com pedúnculo $0,6-2,2 \mathrm{~mm}$ compr., glabro, vernicoso; invólucro campanulado 2,14,2 mm compr., 1,8-2,9 mm larg., 2-3-seriado; brácteas involucrais 1,9-4 $\mathrm{mm}$ compr., $1,5-1,9 \mathrm{~mm}$ larg., ovadas ou oblongas, ápice obtuso, às vezes ciliado, margem inteira, glabras. Receptáculo plano, glabro. Capítulo com 5 flores; corola com tubo 0,9-2 $\mathrm{mm}$ compr., glabro; lacínias $0,5 \mathrm{~mm}$ compr., glandulosas no ápice. Antera com base sagitada, apêndice do conectivo triangular, ápice obtuso. Ramos do estilete papilosos, ápice arredondado. Cipselas obcônicas, 2,5-3 mm compr., 0,6-1 mm diâm., com tricomas rígidos, costas glandulosas; carpopódio simétrico, anelar. Pápus 2-seriado, até $3 \mathrm{~mm}$ compr., cerdas achatadas na base, amareladas.

Material examinado: Minas Gerais, Jaboticatubas, proximidades da divisa do PARNA, rumo à Conceição do Mato Dentro, 7.XII.1992, bot. e fl., H.F. Leitão Filho et al. s.n. (HUFU 6211, UEC 27292).

Symphyopappus decussatus ocorre na Bahia e em Minas Gerais. Na área de estudo pode ser encontrada em campos rupestres. Hattori (2014) aproxima esta espécie de $S$. brasiliensis, no entanto esta apresenta pápus 1-seriado e cipselas glanduloso-pontoadas (vs. pápus 2-seriado e cipselas glabras).

15.5 Symphyopappus reitzii (Cabrera) R.M.King \& H.Rob., Phytologia 22: 116. 1971.

Arbustos, $0,8 \mathrm{~m}$ alt. Ramos castanhos, multicostados, glabros, às vezes glandulosopontoados. Folhas opostas ou alternas, cruzadas ou imbricadas, sésseis; lâminas 0,7-2,6 cm compr., 0,3$1,4 \mathrm{~cm}$ larg., elípticas a lanceoladas, ápice agudo, base decorrente, margem denteada na metade superior, ambas faces glanduloso-pontoadas, vernicosas, paralelódromas. Capitulescência em panículas corimbiformes; capítulos com pedúnculo 0,8-4 mm compr., glabros, vernicosos; invólucro estreito-campanulado, 2,5-6,5 mm compr., 2-4,3 mm larg., 4-seriado; brácteas involucrais com margem inteira, as externas $1,3-1,5 \mathrm{~mm}$ compr., $0,6-1,1 \mathrm{~mm}$ larg., triangulares, ápice agudo ou arredondado, margem ciliada, as medianas 3,2-3,5 mm compr., 1,7$1,75 \mathrm{~mm}$ larg., ovadas, ápice arredondado, face adaxial glanduloso-pontoado, margem serrilhada, as internas 4,9-5,4 mm compr., 2,3-2,4 mm larg., ovadas a lanceoladas, ápice arredondado, margem serrilhada. Receptáculo plano, glabro. Capítulo com 5 flores; corola glabra, tubo $1,4 \mathrm{~mm}$ compr.; limbo $2 \mathrm{~mm}$ compr.; lacínias 1,1 $\mathrm{mm}$ compr., margem papilosa internamente. Anteras com base curtamente sagitada, ápice ovado. Ramos do estilete lineares. Cipselas prismáticas, $1-2,6 \mathrm{~mm}$ compr., 0,5-0,7 mm diâm., tricomas curtos; carpopódio indistinto. Pápus cerdoso, 2-seriado, 3,1-4,2 mm compr.

Material examinado: Minas Gerais, Santana do Riacho, RPPN Brumas do Espinhaço e Ermo dos Gerais, 18.IV.2012, fl., J. Ordones et al. 1892 (BHZB, HUFU); RPPN Brumas do Espinhaço e Ermo dos Gerais, 16.V.2012, bot. e fl., I.R. Andrade et al. 481 (BHZB, HUFU); RPPN Brumas do Espinhaço e Ermo dos Gerais, 16.V.2012, bot. e fl., I.R. Andrade et al. 436 (BHZB, HUFU); RPPN Brumas do Espinhaço e Ermo dos Gerais, 27.XI.2012, bot. e fl., M.G.C. Fernandes et al. 1676 (BHZB, HUFU).

Symphyopappus reitzii ocorre em Minas Gerais e em Santa Catarina. $\mathrm{Na}$ área de estudo pode ser encontrada em campos rupestres. A espécie pode ser reconhecida por apresentar suas folhas imbricadas e, muitas vezes, alternas, elípticas e denteadas na metade superior.

15.6 Symphyopappus uncinatus H.Rob., Compositae Newslett. 38: 52-53. 2002.

Fig. 4C, E

Arbustos, $1-1,5 \mathrm{~m}$ alt. Ramos multicostados, glabros. Folhas opostas; pecíolo 7,4-13 $\mathrm{mm}$ compr., glabro; lâminas 1,7-10,3 cm compr., 0,3-2,7 cm larg., lanceoladas, ápice agudo, base aguda, margem serreada na metade superior, peninérveas. Capitulescência em panículas corimbosas congestas; 
capítulos sesseis a subsésseis; invólucro cilíndrico, 6,3-7,8 mm compr., 2,4-4,3 mm larg., 4-5-seriado; brácteas involucrais com ápice ciliado, as externas 2,5-2,8 mm compr., 1,3-1,4 mm larg., triangulares ou ovadas, ápice arredondado, margem inteira, ciliada ou serrilhada, as medianas 4,4-4,8 mm compr., 1,3-1,7 $\mathrm{mm}$ larg., lanceoladas a oblongo-lanceoladas, ápice agudo, margem serrilhada, as internas 6,4-6,9 mm compr., 1,4-1,6 mm larg., oblongas, ápice arredondado, margem serrilhada. Receptáculo plano, glabro. Capítulo com 5 flores; corola glabra, tubo 4,24,7 mm compr.; limbo indiviso; lacínias 0,4-0,7 mm compr., revolutas. Anteras com base sagitada, apêndice apical oblanceolado, ápice emarginado. Ramos do estilete lineares, ápice levemente espessado. Cipselas 1,8-2,3 mm compr., 0,5-0,8 mm diâm., glabras, costas ciliadas, carpopódio simétrico, anelar. Pápus 1-seriado, 4,2-4,7 mm compr., cerdas com ápice em forma de gancho.

Material examinado: Minas Gerais, Serra do Cipó, trilha para Cahoeira Veu da Noiva, 18.XII.2014, fl., F.L. Contro 30 \& D. Marques (HUFU).

Symphyopappus uncinatus é encontrada somente em Minas Gerais. Na área de estudo ocorre em campos rupestres. A espécie é facilmente distinta pela presença de cerdas do pápus com ápice em forma de gancho.

\section{Trichogonia (DC.) Gardner, London} J. Bot. 5: 459. 1846.

Ervas ou subarbustos, eretos ou raramente prostados. Ramos multicostados, pubescente, glandulosos. Folhas alternas, raramente opostas; sésseis ou pecioladas; lâminas lineares, lanceoladas, elípticas, triangulares, ovadas ou cordadas, margem crenada ou serreada. Capitulescência em panículas corimbosas laxas; capítulos subsésseis a pedunculados; invólucro campanulado, geralmente 2seriado. Receptáculo plano ou convexo, epaleáceo. Capítulo com 10-110 flores; corola branca, rosa ou arroxeada, tubo glabro, limbo pubescente, lacínias triangulares, densamente pubescentes ou com tricomas glandulares. Anteras com apêndice arredondado, obtuso ou agudo, colar cilíndrico. Ramos do estilete lineares a levemente clavados, papilosos ou mamilosos, base não alargada, glabra. Cipselas prismáticas, estipitadas ou não, raramente glabras. Pápus plumoso, persistente, 1-seriado.

Trichogonia é um gênero da América do Sul com cerca de 20 espécies (Roque et al., 2012). No Brasil existem 17 espécies, das quais 14 são endêmicas. Estabelecido por Gardner (1846), através de um trabalho de De Candolle (1836) o gênero é reconhecido por apresentar as séries de brácteas em mesmo comprimento, corola pilosa externamente, cipsela com 5 costas e tricomas nas costas.
Trichogonia é comumente confundido, principalmente em herbários, com algumas espécies de Ageratum L., porém difere pela presença de tricomas nos lobos da corola e presença de pápus plumoso ( $v s$. lobos da corola glabros e ausencia de pápus ou, quando presente, pápus coroniforme).

Chave de identificação para as espécies de Trichogonia:

1. Folhas sésseis; planta densamente glutinosa

1'. Folhas pecioladas; planta não glutinosa.

2. Capitulescência em panículas; lâmina foliar cordada ou ovada .............................. 16.2 T. hirtiflora

2'. Capitulescência em panículas corimbiformes;

lâmina foliar linear ou lanceolada.

3. Capítulos grandes (40-50) flores; cipsela estipitada .........................16.3 T. salviifolia

3'. Capítulos pequenos (até 23 flores); cipsela não estipitada ........16.1 T. grazielae

16.1 Trichogonia grazielae R.M.King \& H.Rob, Phytologia 45: 106. 1980.

Subarbustos a arbustos, $0,5 \mathrm{~m}$ alt. Ramos multicostados, tricomas glandulares. Folhas alternas; pecíolo 1,7-15,7 $\mathrm{mm}$ compr., tricomas glandulares; lâminas $0,7-7,6 \mathrm{~cm}$ compr., 0,2-2,2 cm larg., lanceoladas, ápice agudo ou acuminado, base aguda ou arredondada, margem serreada, face adaxial esparsamente glanduloso-estipitado, face abaxial glanduloso-pontoada, esparsamente hirsuta, camptódromas. Capitulescência em panículas corimbiformes; capítulos com pedúnculo 1,5-4,4 mm compr., glanduloso-estipitado; invólucro 2-seriado; brácteas involucrais 3,9-4,7 mm compr., 0,8-0,9 mm larg., lanceoladas, ápice agudo, densamente piloso, margem ciliada na metade superior, face adaxial pilosa, glanduloso-pontoada. Receptaculo plano, glabro. Capítulo com 23 flores; corola com fauce alargada; tubo 2,9 mm compr.; lobos $0,8 \mathrm{~mm}$ compr., face externa pilosa. Anteras com apêndice apical emarginado, base arredondada. Ramos do estilete com ápice espessado, papilosos. Cipselas estipitadas, 1,9-2,3 mm compr., 0,4-0,6 mm diâm., pilosa próximo ao carpopódio; carpopódio simétrico, anelar. Pápus 2,7 mm compr., cerdas espessadas na base.

Material examinado: Minas Gerais, Santana do Riacho, trilha da Cachoeira da Farofa, 3.II.2006, fl., C.S. Sato \& C.A. Garcia 69 (SPF).

Trichogonia grazielae é encontrada em Goiás e Minas Gerais. Segundo Roque et al. (2012) a espécie pode ser encontrada em cerrado s.l. e caracteriza a espécie pela presença de folhas grandes $(9 \mathrm{~cm})$ e lanceoladas, margem serreada e base atenuada. 
16.2 Trichogonia hirtiflora (DC.) Sch.Bip. ex Baker, FI. Bras. 6 (2): 214. 1876.

Arbusto, até $0,7 \mathrm{~m}$ alt. Ramos estriados, hirsutos, glanduloso-pontoados. Folhas alternas; pecíolo 0,9-4 $\mathrm{mm}$ compr., hirsuto, glandulosopontoado, lâminas 4,1-20,1 mm compr., 2,8-14 mm larg., ovadas ou cordadas, ápice agudo, base cordada, margem serreada, face adaxial esparso-hirsuta, face abaxial tomentosa, glanduloso-pontoada, nervuras imersas no limbo, actinódromas. Capitulescência em panículas; invólucro 6,3-9,8 mm compr., 5,8-10,2 mm larg., 2-seriado; brácteas involucrais 3,6-5,4 mm compr., 0,6-1,3 mm larg., lanceoladas, ápice agudo, margem ciliada, face adaxial hirsuta, glandulosopontoada. Receptáculo plano-alveolado, glabro. Capítulo com até 41 flores; corola com fauce alargada; tubo 1,3 mm compr., lilás, densamente pubescente no terço superior. Anteras com apêndice apical oblongo, base curtamente sagitada. Ramos do estilete lineares, ápice espessado, papilosos. Cipselas com bases estipitadas, 3,2-3,8 mm compr., 0,5-0,7 mm diâm., esparso-hirsutas, glanduloso-pontoada; carpopódio simétrico, anelar. Pápus 2,6-3 mm compr.

Material examinado: Minas Gerais, Congonhas do Norte, Serra da Carapina, 3.III.1998, fl. e fr., J.R. Pirani et al. 4178 (HUFU, SPF); Congonhas do Norte, estrada para Gouveia, entrada da Fazenda do Lelo, bot. e fl., F.L. Contro 37 \& D. Marques (HUFU); Santana do Riacho, Alto do Palácio, 19¹5'68" S e 4331'93" W, fl. e fr., F.L. Contro 18 \& D. Marques (HUFU); Estrada para Conceição do Mato Dentro, próximo ao trevo para Morro do Pilar, 19¹3'34"S $43^{\circ} 30^{\prime} 20^{\prime \prime W}$, bot., fl. e fr., F.L. Contro et al. 95 (HUFU); Congonhas do Norte, Estrada para Santana do Riacho, Serra da Carapina (Serra Talhada na folha IBGE), 18 $8^{\circ} 56^{\prime} S$ $43^{\circ} 41^{\prime} \mathrm{W}$, bot. e fl., J.R. Pirani et al. CFSC 4178 (HUFU, SPF); Jaboticatubas, nas proximidades da divisa do Parque, rumo à Conceição do Mato Dentro, 7.XII.1992, bot. e fl., H.F. Leitão Filho et al. s.n. (HUFU 6196, UEC 27296); Congonhas do Norte, Retiro do Bárbaro, morro à esquerda do Rio Preto, $18^{\circ} 53^{\prime} S 43^{\circ} 46^{\prime} \mathrm{W}, 22 . I V .1982$, fl. e fr., M.C.E. Amaral et al. CFSC 8383 (SPF); Santana do Riacho, Morro do Breu, $19^{\circ} 04^{\prime} 20^{\prime \prime}-05^{\circ} 20^{\prime} \mathrm{S} 43^{\circ} 39^{\prime} 20^{\prime \prime}-40^{\circ} 20^{\prime} \mathrm{W}, 16-17 . I I .1982$, bot. e fl., N. Hensold 477 (SPF); Serra do Cipó, estrada para Conceição do Mato Dentro, aproximadamente $\mathrm{Km} \mathrm{125,}$ 19¹4'02"S 4330'34"W, 30.VI.2015, bot. e fl., F.L. Contro et al. 91 (HUFU); Santana do Riacho, Morro do Breu, 1904'20"-05'20"S 4339'20"-40'20"W, 16-17.II.1982, bot. e fl., N. Hensold 477 CFSC 8553 (SPF); Santana do Pirapama, acesso pela Fazenda Inhame, subida da Serra do Cipó, a

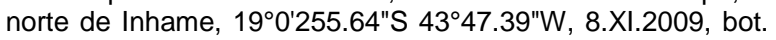
e fl., D.C. Zappi 2299 (RB); Santana do Pirapama, Serra da Lapa, distrito de São José da Cachoeira, trilha da Senhorinha, $18.9422^{\circ} \mathrm{S} 43.7498^{\circ} \mathrm{W}, 19.1 \mathrm{l} .2007$, fl. e fr., V.C. Souza et. al. 32822 (ESA).

Trichogonia hirtiflora é encontrada apenas na Bahia e em Minas Gerais. A espécie é facilmente reconhecida das demais existentes na área por apresentar folhas pequenas (até $2 \mathrm{~cm}$ ), ovadas ou cordadas, margem crenada e anteras com apêndice apical oblongo. Roque et al. (2012) sinonimizam as seguintes espécies à $T$. hirtiflora: Trichogonia apparicioi G.M.Barroso, Trichogonia crenulata
(Gardner) D.J.N.Hind e Trichogonia margarethiae Soares Nunes.

16.3 Trichogonia salviifolia Gardner, London J. Bot. 5: 460. 1846.

Subarbusto, $0,4 \mathrm{~m}$ alt. Ramos incanos, tricomas glandular-estipitados, vináceos. Folhas inferiores opostas, superiores alternas; pecíolo 1,819,2 mm compr., tricomas glandulares; lâminas 5,347,9 mm compr., 1,9-16 mm larg., lanceoladas, ápice agudo, base truncada, subcordada, obtusa, raramente assimétrica, margem crenada ou às vezes crenadoserreada a serreada, ambas faces setosas, glanduloso-pontoadas, eucamptódromas. Capitulescência em panículas corimbiformes; capítulos com pedúnculo 1,2-5,3 $\mathrm{mm}$ compr., tricomas glandulares; invólucro estreito-campanulado, 1,6-4,9 $\mathrm{mm}$ compr., 1,1-3,8 $\mathrm{mm}$ larg., 2-seriado; brácteas involucrais 2,6-5,2 $\mathrm{mm}$ compr., 0,6-1,1 $\mathrm{mm}$ larg., oblongas, ápice agudo ou arredondado, densamente pubescente, margem inteira, face adaxial com tricomas glandulares. Receptáculo plano-alveolado, glabro. Capítulo com até 24 flores; corola com tubo 1,5-2,5 mm compr.; limbo 0,6-0,8 mm compr., glabro; lacínias ca. $0,4 \mathrm{~mm}$ compr., face adaxial densamente pubescentes. Anteras com base arredondada, apêndice apical ovado. Ramos do estilete lineares, ápice espessado, mamilosos. Cipselas estipitadas, 1,3-2,8 mm compr., 0,4-0,6 mm diâm., pilosas; carpopódio assimétrico, anelar. Pápus 1-2,7 mm compr.

Material examinado: Minas Gerais, Congonhas do Norte, estrada para Gouveia, entrada da Fazenda do Lelo, 19.XII.2014, bot. e fl., F.L. Contro 36 \& D. Marques (HUFU); Congonhas do Norte, estrada para Gouveia, entrada da Fazenda do Lelo, 19.XII.2014, bot. e fl., F.L. Contro 39 \& D. Marques (HUFU); Santana do Riacho, Trilha do Cânion das Bandeirinhas, 16.XII.2014, bot., fl. e fr., F.L. Contro 8 \& D. Marques (HUFU).

Trichogonia salviifolia ocorre na Bahia, Ceará, Espírito Santo, Goiás, Mato Grosso do Sul, Minas Gerais, Pernambuco, Piauí, Rio de Janeiro, São Paulo e Distrito Federal, em Caatinga, Cerrado e Mata Atlântica. $\mathrm{Na}$ área de estudo pode ser encontrada em campo rupestre. É semelhante à Trichogonia villosa por apresentar as lâminas lanceoladas com margem serreada e tricomas glandulares, no entanto $T$. salviifolia apresenta capítulos pequenos, com até 24 flores, folhas pecioladas e cipselas pilosas (vs. capítulos grandes, 40-50 flores, folhas sésseis e cipselas com tricomas glandulares).

16.4 Trichogonia villosa Sch.Bip. ex Baker, FI. Bras. 6 (2): 213. 1876.

Fig. 4F-H

Subarbustos a arbustos, 1-2 $\mathrm{m}$ alt., densamente glutinosa. Ramos com tricomas glandulares. Folhas alternas, sésseis; lâminas 4,9- 
35,4 mm compr., 0,6-3,2 mm larg., lineares ou linearlanceoladas, ápice obtuso, base decorrente, margem serreada ou inteira, ambas faces com tricomas glandulares, hifódromas. Capitulescência em panículas; capítulos com pedúnculo 2,7-19,9 mm compr., tricomas glandulares; invólucro 1,6-6,5 mm compr., 0,8-10,5 mm larg., 2-seriado; brácteas involucrais 5,5-8,6 mm compr., 0,6-1,8 $\mathrm{mm}$ larg., lanceoladas a linear-lanceoladas, ápice agudo ou longo acuminado, margem inteira, face adaxial com tricomas glandulares. Receptáculo plano-alveolado, glabro. Capítulo com 40-50 flores; corola com tubo 1,3-2,7 mm compr.; limbo 1,4-1,8 mm compr.; lacínias ca. $0,5 \mathrm{~mm}$ compr., face adaxial pubescentes. Anteras com base curtamente sagitada, apêndice apical emarginado. Ramos do estilete lineares, espatados no ápice, mamilosos. Cipselas estipitadas, 0,8-4 mm compr., 0,4-0,7 mm diâm., costas pubescentes, tricomas glandulares entre as costas; carpopódio simétrico, anelar. Pápus 3,2-4,9 mm compr.

Material examinado: Minas Gerais, Santana do Riacho, PARNA Serra do Cipó, trilha do Cânion das Bandeirinhas, final da trilha, 16.XII.2014, fl. e fr., F.L. Contro 14 \& D. Marques (HUFU); Santana do Riacho, PARNA Serra do Cipó, Alto do Palacio, 17.XII.2014, bot. e fl., F.L. Contro $20 \&$ D. Marques (HUFU); Santana do Riacho, trilha para Cachoeira Véu da Noiva, 18.XII.2014, bot., fl. e fr., F.L. Contro 28 \& D. Marques (HUFU); Serra do Cipó, estrada para Conceição do Mato Dentro, $19^{\circ} 22^{\prime} 49^{\prime \prime S} 43^{\circ} 40^{\prime} 13^{\prime \prime W}$, 29.VI.2015, bot. e fl., F.L. Contro et al. 69 (HUFU); Serra do Cipó, estrada para RPPN Brumas do Espinhaço, $19^{\circ} 04^{\prime} 11^{\prime \prime S} 43^{\circ} 42^{\prime} 24 " \mathrm{~W}, 2 . \mathrm{VII} .2015$, bot., fl. e fr., F.L. Contro et al. 146 (HUFU); PARNA Serra do Cipó, entre os km 132 e 134, 7.XII.1949, bot., fl. e fr., A.P. Duarte 2141 (HUFU, RB); Serra do Cipó, km 131 a 132, 4.XII.1949, fl. e fr., A.P. Duarte 2052 (RB); PARNA Serra do Cipó, trilha para cachoeiras e capão, 15.XII.2014, bot., fl. e fr., F.L. Contro 7 \& D. Marques (HUFU); Serra do Cipó, estrada Lagoa Santa-Conceição do Mato Dentro, km 118, 12.XII.1994, fl., N.M. Castro 436 (HUFU); Estrada Lagoa Santa-Conceição do Mato Dentro, km 106, 12.XII.1994, fl., N.M. Castro 337 (HUFU); PARNA Serra do Cipó, descida da Serra das Bandeirinhas, 28.VII.1991, fl. e fr., A.M. Giulietti et al. CFSC 12596 (SPF); Serra do Cipó, rodovia Belo Horizonte-Conceição do Mato Dentro, km 125, elevação em frente à estatua do Velho Juca, 26.IV.1991, bot. e fl., J.R. Pirani et al. CFSC 12251 (SPF).

Trichogonia villosa ocorre somente nos estados da Bahia e Minas Gerais, em Cerrado e Mata Atlântica. Na área de estudo pode ser encontrada em campos rupestres, cerrado rupestre e borda de cerrado. A espécie pode ser reconhecida pela presença de glândulas em grande densidade e folhas alternas quase em fascículos.

Roque et al. (2012) sinonimizaram Trichogonia villosa var. multiflora, devido à ausência de características morfológicas, biogeográficas ou ecológicas para distinção a nível infraespecifico.

\section{Vittetia R.M.King \& H.Rob., Phytologia 29: 122. 1974.}

Subarbustos a arbustos eretos. Ramos cilíndricos, hirtos. Folhas opostas ou alternas; curtopecioladas a subsésseis, lâmina orbicular a ovada ou oblonga, base arredondada, margem inteira a crenado-serreada, paralelódroma. Capitulescência em panículas corimbosas; invólucro eximbricado, 2seriado. Receptáculo plano, epaleaceo ou piloso. Capítulo com 10-21 flores; corola branca a rosaescuro, funeiforme ou com base estreita, limbo campanulado, lacínias ovado-triangulares, mais longas do que largas, glandulosas externamente. Anteras com apêndice ovado, mais longo do que largo, colar curto-cilindrico. Ramos do estilete lineares ou clavados, papilosos; base não alargada, glabra. Cipsela prismática, glandulosa; carpopódio anelar ou curto-cilindrico. Pápus cerdoso, unisseriado, cerdas com ápice agudo.

São reconhecidas apenas 2 espécies para o gênero, Vittetia bishopii R.King \& H.Rob. e Vittetia orbiculata (DC.) R.M.King \& H.Rob., sendo este endêmico do Brasil. No Brasil as espécies encontramse distribuidas em Minas Gerais, Paraná, Santa Catarina e São Paulo, em Cerrado e Mata Atlântica.

Vittetia é o único membro de Gyptidinae com cipselas 7-costadas (King \& Robinson 1987). King \& Robinson (1975) relacionam o gênero com Urolepis (DC.) R.M.King \& H.Rob. e Gyptidium R.M.King \& H.Rob., que possuem corola com tubo estreito, porém estes apresentam limbo mais ou menos campanulado e cipselas 5-costadas

17.1 Vittetia bishopii R.M.King \& H.Rob., Phytologia 49: 281. 1981.

Fig. 4I, J

Subarbustos, 0,4-0,45 $\mathrm{m}$ alt. Ramos costados, setosos, glanduloso-pontoados. Folhas alternas, subsésseis ou com pecíolo até 1,35 mm compr., glanduloso-pontoado; lâminas 6,8-19,8 mm compr., 2,3-14,3 mm larg., elípticas a largo-elipticas, ápice arredondado ou agudo, base aguda, margem inteira, revoluta, face adaxial esparsamente setosa, glanduloso-pontoada, face abaxial esparso-setosa a glabra, glanduloso-pontoada, actinódromas. Capitulescência paniculiforme, terminal; capítulos com pedúnculo 3,6-14 $\mathrm{mm}$ compr., densamente setoso, glanduloso-pontoado; invólucro campanulado, 3,7-9,1 mm compr., 2,4-8,9 mm larg.; brácteas involucrais 48,8 mm compr., 0,8-2,2 mm larg., linear-lanceoladas a lanceoladas, ápice agudo ou acuminado, margem inteira, ciliada, face adaxial setosa, glandulosopontoada. Receptáculo piloso. Capítulos com 12 flores; corola (em botão) glanduloso-pontoada. Anteras com apêndice apical ovado, base sagitada. 


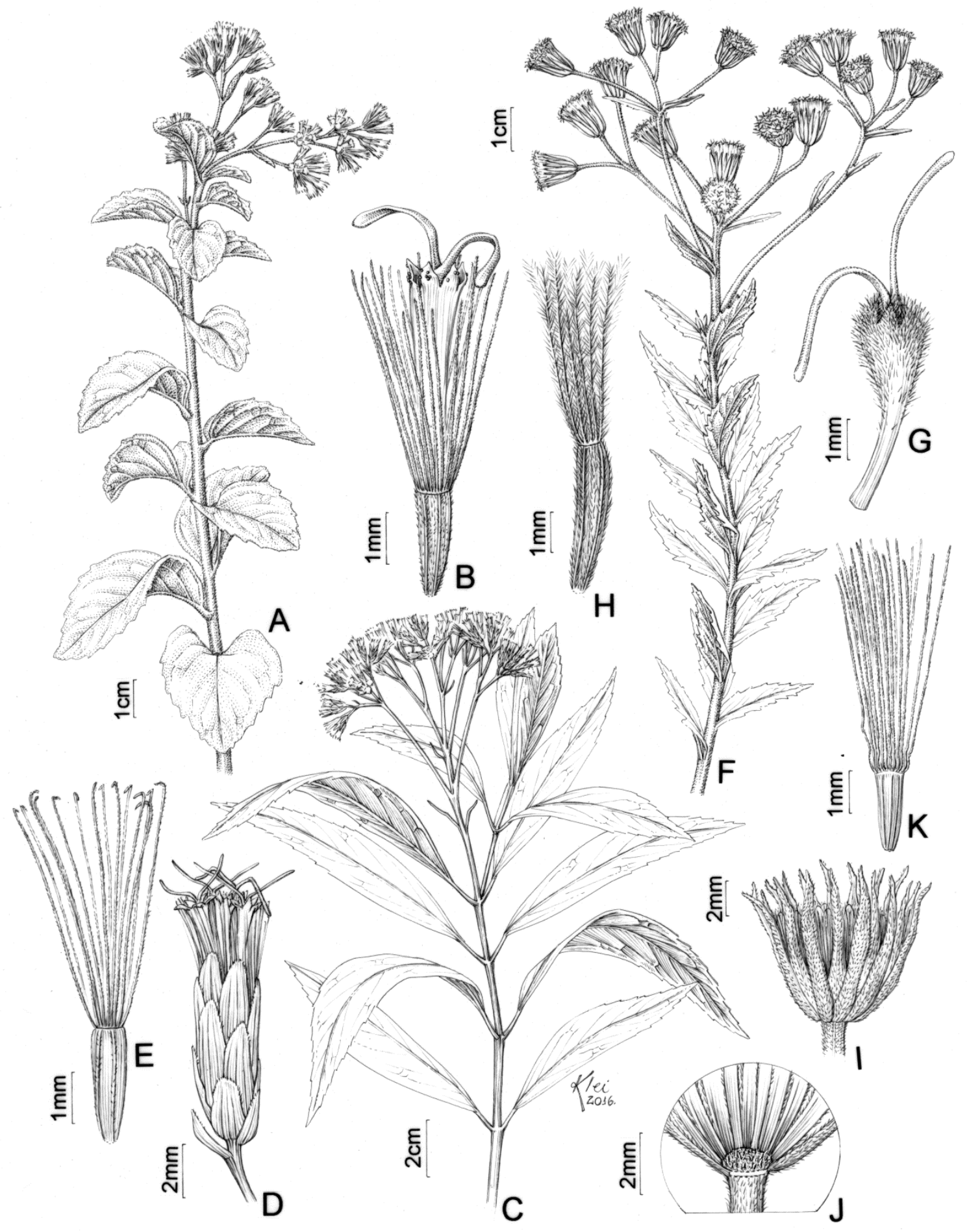

Fig. 4: A-B. Stomatanthes polycephalus (Sch.Bip. ex B.L.Rob.)H.Rob. A. Ramo. B. Cispela e pápus. C-E. Symphyopappus uncinatus H.Rob. C. Ramo. D. Capítulo. E. Cipsela e pápus. F-H. Trichogonia villosa Sch.Bip. ex Baker. F. Ramo. G. Detalhe da corola com lobos pilosos. H. Cipsela e pápus. I-J. Vittetia bishopii R.M.King \& H.Rob. I. Involucro. J. Detalhe do receptáculo (C. F.L.Contro 30; F. F.L.Contro 69). 
Ramos do estilete lineares, espessados no ápice, papilosos. Cipselas 1-1,2 mm compr., 0,4-0,5 mm larg., glanduloso-estipitadas, tricomas simples; carpopódio alargado. Pápus 2,4-2,8 mm compr.

\begin{abstract}
Material examinado: Minas Gerais, Serra do Cipó, km 138 estrada para Conceição do Mato Dentro, 6.XII.1949, fl., A.P. Duarte 2150 (RB).
\end{abstract}

Vittetia bishopii A espécie é endêmica de Minas Gerais, em áreas de Cerrado. $\mathrm{Na}$ área de estudo ocorre em brejo alto pós-queimada. King \& Robinson (1981) aproximam esta espécie de Vittetia orbiculata (DC.) R.M.King \& H.Rob. pela presença de folhas subsésseis, 7-8 costas na cipsela, capítulos com 10-12 flores e corola glandulosa.

Vittetia bishopii pode ser reconhecida pelo invólucro eximbricado, receptáculo plano, lacínias da corola ovadas e base do estilete não alargada (King \& Robinson, 1981). O tipo da espécie baseia-se em um material da Serra do Cipó.

\section{Agradecimentos}

Os autores agradecem à curadoria dos herbários SPF e HUFU pela disponibilização dos seus acervos e infra-estrutura oferecida; à CAPES pela bolsa de demanda social para a primeira autora; ao Klei Souza pelas ilustrações; ao Programa de Pósgraduação em Biologia Vegetal da UFU, CNPq e CAPES (REFLORA Proc. 563541/2010-5; PROTAX Proc. 562290/2010-9) pelo apoio financeiro; o segundo autor agradece à FAPEMIG pelo financiamento dos estudos com a tribo Eupatorieae (Asteraceae) no Estado de Minas Gerais (PPM VIII, Proc. PPM-0038514); ao ICMBIO e Parque Nacional da Serra do Cipó pela licença de coleta concedida; aos revisores pelos comentários para o aprimoramento deste trabalho.

\section{Referências}

ALMEIDA, G.S.S. 2008. Asteraceae Dumort. Nos campos rupestres do Parque Estadual do Itacolomi, Minas Gerais, Brasil. Tese de Doutorado, Universidade Federal de Viçosa. Viçosa.

Asteraceae in Flora do Brasil 2020 em construção. Jardim Botânico do Rio de Janeiro. Disponível em: http://floradobrasil.jbrj.gov.br/reflora/floradobrasil/F B16272. Acesso em Maio/2017.

BALDWIN, B.G. 2009. Heliantheae alliance. In V.A. Funk, A. Susana, T.F. Stuessy \& R.J. Bayer (eds.). 2009. Systematics, Evolution, and Biogeography of Compositae. International Association for Plant Taxonomy (IAPT). Vienna, p 689-708.
BARROSO, G.M. 1986. Sistemática de Angiospermas do Brasil. vol. III. Imprensa Universitária da Universidade Federal de Viçosa. Viçosa.

BAUTISTA, H.P. 2000. Sistemática e filogenia de um gênero endêmico do Brasil: Acritopappus R.M.King \& H.Rob. (Asteraceae, Eupatorieae). Tese de Doutorado, Universidade de Santiago de Compostela. Santiago de Compostela.

BORGES, R.A.X., SAAVEDRA, M.M., NAKAJIMA, J.N. \& FORZZA, R.C. 2010. The Asteraceae flora of Serra do Ibitipoca: analyses of its diversity and distribution compared with selected áreas in Brazilian mountain ranges. Syst. Biodiv. 8(4): 471-479.

ESTEVES, R.L. 2001. O gênero Eupatorium s.l. (Compositae - Eupatorieae) no Estado de São Paulo, Brasil. Tese de Doutorado, Universidade Estadual de Campinas. Campinas.

FERNANDES, A.C. 2014. Sistemática de Heterocondylus R.M.King \& H.Rob. (Eupatorieae, Asteraceae). Tese de Doutorado, Universidade Federal de Belo Horizonte. Belo Horizonte.

FUNK, V.A., SUSANNA, A., STUESSY, T. F. \& BAYER, R. J. 2009. Systematics, Evolution, and Biogeography of Compositae. International Association for Plant Taxonomy (IAPT). Vienna.

GIULIETTI, A.M., MENEZES, N.L., PIRANI, J.R., MEGURO, M. \& WANDERLEY, M.G.L. 1987. Flora da Serra do Cipó, Minas Gerais: caracterização e lista das espécies. Bol. Bot. Univ. São Paulo 9: 1-151.

GROSSI, M.A. Stomatanthes in Flora do Brasil 2020 em construção. Jardim Botânico do Rio de Janeiro. Disponível em: http://floradobrasil.jbrj.gov.br/ reflora/floradobrasil/FB16324. Acesso em Maio de 2017.

HATTORI, E.K.O. \& NAKAJIMA, J.N. 2008. A família Asteraceae na Estação de Pesquisa e Desenvolvimento Ambiental Galheiro, Perdizes, Minas Gerais, Brasil. Rodriguésia 59(4): 687-749.

HATTORI, E.K.O. \& NAKAJIMA, J.N. 2011. A família Asteraceae na Reserva Ecológica do Panga, Uberlândia, Minas Gerasi, Brasil. Hoehnea. 38(2):

JOHNSON, M.F. 1971. A monograph of the genus Ageratum L. (Compositae-Eupatorieae). Ann. Missouri Bot. Gard. 58: 6-88.

KING, R.M. \& ROBINSON, H. 1987. The genera of Eupatorieae (Asteraceae). Monographs in Systematic Botany. Missouri Botanical Garden. Saint Louis. 
NAKAJIMA, J.N. \& SEMIR, J. 2001. Asteraceae do Parque Nacional da Serra da Canastra, Minas Gerais, Brasil. Revta Bras. Bot. 24(4): 471-478.

NAKAJIMA, J.N. Ageratum in Lista de Espécies da Flora do Brasil. Jardim Botânico do Rio de Janeiro. Disponivel em: http://floradobrasil.jbrj.gov.br/jabot/fl oradobrasil/FB15932. Acesso em 01 Jun. 2017.

OLIVEIRA, C.T. 2015. Praxelis in Lista de Espécies da Flora do Brasil. Jardim Botânico do Rio de Janeiro. Disponivel em: <http://floradobrasil.jbrj.gov.br/jabot/ floradobrasil/FB16265>

QUARESMA, A.S. 2013. A tribo Eupatorieae (Astreaceae) no Planalto de Diamantina, Minas Gerais, Brasil. Dissertação de Mestrado, Universidade Estadual de Feira de Santana. Feira de Santana.

PACHECO, R.A. 2014. A família Asteraceae na Serra dos Pirineus, Goiás, Brasil. Dissertação de Mestrado, Universidade Federal de Uberlândia, Uberlândia, Minas Gerais.
REIS, G.H., MANSANARES, M.E., DOMINGOS, D.Q., MEIRELES, L.D. \& BERG, E. van der. 2015. Asteraceae dos Campos Rupestres das Serras da Bocaina e de Carrancas, Minas Gerais, Brasil. Rodriguésia 66 (3): 829-845.

RITTER, M.R. \& MIOTTO, S.T.S. 2005. Taxonomia de Mikania Willd. (Asteraceae) no Rio Grande do Sul, Brasil. Hoehnea 32 (3): 309-359.

RITTER, M.R., LIRO, R.M., ROQUE, N., NAKAJIMA, J.N., SOUZA-BUTURI, F.O. \& OLIVEIRA, C.T. 2015. Mikania in Lista de Espécies da Flora do Brasil. Jardim Botânico do Rio de Janeiro. Disponivel em: <http://floradobrasil.jbrj.gov.br/jabot/ floradobrasil/FB5344>.

ROQUE, N., BAUTISTA, H.P. \& MOTA, A.C. 2012. Taxonomic revision of Trichogonia (Eupatorieae, Asteraceae): a South American Genus. Syst. Bot. 37(2): 525-553. 